\title{
CTUIR UMATILLA ANADROMOUS FISHERIES HABITAT PROJECT A Columbia River Basin Fish Habitat Project
}

\section{Annual Report}

February 1, 2007 to January 31, 2008

Fiscal Year 2007

\author{
CONTRACT \# 32047 \\ Northwest Power Planning Council Project \# 1987-100-01 \\ Prepared For: \\ United States Department of Energy \\ Bonneville Power Administration
}

Prepared By:

Eric D. Hoverson

Project Leader - Umatilla Anadromous Fisheries Habitat Project

$\&$

Alexandra Amonette

Spring Rise

Confederated Tribes Umatilla Indian Reservation

Department Natural Resources Fish and Wildlife Program

CONFEDERATED TRIBES UMATILLA INDIAN RESERVATION

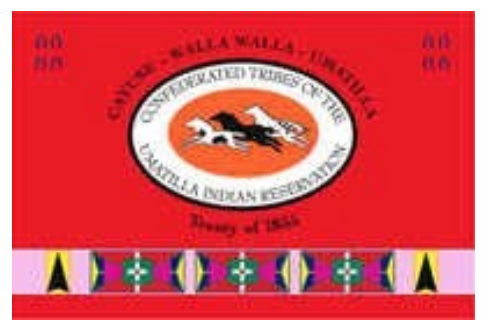

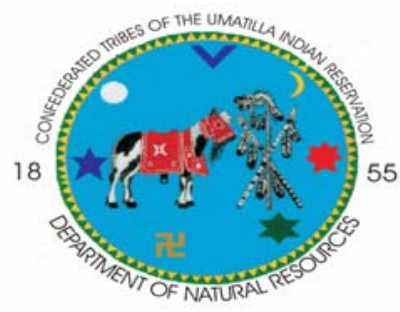

BONNEVILLE POWER ADMINISTRATION

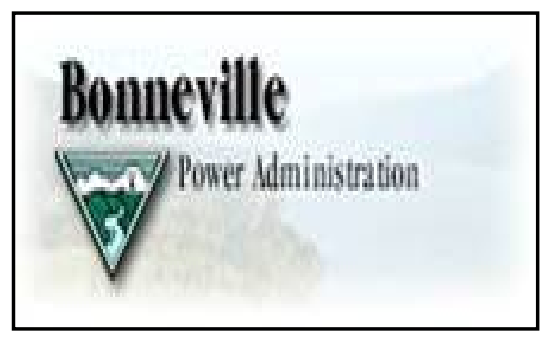




\title{
Confederated Tribes of the Umatilla Indian Reservation Administrative Summary
}

\author{
Project Headquarters: \\ Department of Natural Resources \\ Fish and Wildlife Program \\ Confederated Tribes of the Umatilla Indian Reservation \\ PO Box 638 \\ Pendleton, OR 97801
}

\begin{abstract}
Administrative Contact:
Julie Burke

Confederated Tribes of the Umatilla Indian Reservation Department of Natural Resources

Fish and Wildlife Program Administrative Manager

Phone: 541-966-2372 or 541-276-4109

E-mail: julieburke@ctuir.com

Fax: 541-966-2397

\section{Technical Contacts:}

Eric D. Hoverson

Confederated Tribes of the Umatilla Indian Reservation Department of Natural Resources Project Leader - Umatilla Anadromous Fisheries Habitat Project

Phone: 541-966-2378

E-mail: erichoverson@ctuir.com

James G. Webster

Confederated Tribes of the Umatilla Indian Reservation Department of Natural Resources

Fish Habitat Program Manager

Phone: 541-966-2396

E-mail: jameswebster@ctuir.com
\end{abstract}

\author{
BPA CONTRACTING OFFICER \\ TECHNICAL REPRESENTATIVE: \\ Timmie Mandish \\ 503-230-3502 \\ Email: tamandish@bpa.gov
}

\section{Suggested Citation:}

Hoverson, Eric D. and Webster, James G. 2007. CTUIR Umatilla Anadromous Fisheries

Habitat Project Annual Report, Fiscal Year 2007. Confederated Tribes of the Umatilla Indian Reservation, report submitted to Bonneville Power Administration, Project No. 1987-100-01. 


\begin{abstract}
The Umatilla Anadromous Fisheries Habitat Project (UAFHP) is an ongoing effort to protect, enhance, and restore riparian and instream habitat for the natural production of anadromous salmonids in the Umatilla River Basin, Northeast Oregon. Flow quantity, water temperature, passage, and lack of in-stream channel complexity have been identified as the key limiting factors in the basin. During the 2007 Fiscal Year (FY) reporting period (February 1, 2007January 31, 2008) primary project activities focused on improving instream and riparian habitat complexity, migrational passage, and restoring natural channel morphology and floodplain function. Eight fisheries habitat enhancement projects were implemented on Meacham Creek, Camp Creek, Greasewood Creek, Birch Creek, West Birch Creek, and the Umatilla River. Specific restoration actions included: (1) rectifying five fish passage barriers on four creeks, (2) planting 1,275 saplings and seeding 130 pounds of native grasses, (3) constructing two miles of riparian fencing for livestock exclusion, (4) coordinating activities related to the installation of two off-channel, solar-powered watering areas for livestock, and (5) developing eight water gap access sites to reduce impacts from livestock. Baseline and ongoing monitoring and evaluation activities were also completed on major project areas such as conducting photo point monitoring strategies activities at the Meacham Creek Large Wood Implementation Project site (FY2006) and at all existing easements and planned project sites. Fish surveys and aquatic habitat inventories were conducted at project sites prior to implementation. Monitoring plans will continue throughout the life of each project to oversee progression and inspire timely managerial actions. Twenty-seven conservation easements were maintained with 23 landowners. Permitting applications for planned project activities and biological opinions were written and approved. Project activities were based on a variety of fisheries monitoring techniques and habitat assessments used to determine existing conditions and identify factors limiting anadromous salmonid abundance. Proper selection and implementation of the most effective site-specific habitat restoration plan, taking into consideration the unique characteristics of each project site, and conducted in cooperation with landowners and project partners, was of paramount importance to ensure each project's success.
\end{abstract}




\section{ACKNOWLEDGEMENTS}

The author would like to sincerely thank the following dedicated employees of the Confederated Tribes of the Umatilla Indian Reservation (CTUIR): Julie Burke, Catherine Dickson, Teara Farrow-Ferman, Craig Kvern, Jerry Lauer, Carey Miller, Eric Quaempts, Paul Raab, Donald Sampson, Aaron Skirvin, and James Webster for oversight and leadership and Larry Allen, Randy Bonifer, Billy Goodrich, Scott O’Daniel, Celeste Reeves, Stacy Schumacher, and Brandi Weaskus for their support, professionalism and team atmosphere. Additional thanks to all good stewards of the land who treat all aspects with respect.

Our restoration work to enhance and protect anadromous salmonid habitat is dependent on the contributions and cooperation of many government and tribal organizations and individuals, private landowners, and small businesses, without whom we would be unable to achieve a desired level of success. We are grateful to the following cooperating partners: American Fisheries Society, American Rivers, Anderson Perry \& Associates, Aquatic Contracting, Bauer \& Gustafson Resources, Becker Construction, Blue Mountain Land Trust, Bonneville Power Administration, Clear Creek Cattle Company, Columbia Helicopters, Columbia River Inter Tribal Fish Commission, Cunningham Sheep Company, Double Rock Ranch, Ellis Hunting Ranch, Forth Ranch, GeoEngineers, Hoskins Ranches, McClain Spraying, McMillen Engineering, National Marine Fisheries Services, Natural Reclamation Service, Oregon Fish and Wildlife, Oregon Department of State Lands and Forestry, Oregon State Parks and Historical Society, Oregon Water Resources Department, Oregon Watershed Enhancement Board, Peterson Ranches, South County Helicopter, Spratling Farms, Steve Lindley Contracting, Umatilla Soil and Water Conservation District, Umatilla Basin Watershed Council, Union Pacific Railroad, United States Bureau of Indian Affairs, United States Fish and Wildlife Service, United States Forest Service, United States Army Corps of Engineers, United States Department of Agriculture Farm Service Agency and Natural Resource Conservation Service, Oregon Watershed Enhancement Board, Pacific Coastal Salmon Recovery Fund, Umatilla County, UmatillaMorrow Education Service District, Wallace Drilling, Wild West Riparian, and Whitney Land Company. 


\section{ACRONYMS}

\begin{tabular}{|c|c|}
\hline BA & biological assessment \\
\hline BMHRC & Blue Mountain Habitat Restoration Council \\
\hline BPA & Bonneville Power Administration \\
\hline cfs & cubic feet per second \\
\hline COTR & Contracting Officer Technical Representative \\
\hline CTUIR & Confederated Tribes of the Umatilla Indian Reservation \\
\hline $\mathrm{dbh}$ & diameter at breast height \\
\hline DNR & Department of Natural Resources \\
\hline EPA & United States Environmental Protection Agency \\
\hline ESA & Federal Endangered Species Act \\
\hline ESU & Evolutionary Significant Unit \\
\hline $\mathrm{ft}$ & foot/feet \\
\hline FY & fiscal year \\
\hline GA & geographical area \\
\hline in. & inch/inches \\
\hline LWD & large woody debris \\
\hline $\mathrm{m}$ & meters \\
\hline NMFS & National Marine Fisheries Service \\
\hline NOAA & National Oceanic and Atmospheric Administration \\
\hline NPPC & Northwest Power Planning Council \\
\hline NWPCC & Northwest Power and Conservation Council \\
\hline NRCS & Natural Resource Conservation Service \\
\hline ODEQ & Oregon Department of Environmental Quality \\
\hline ODFW & Oregon Department of Fish and Wildlife \\
\hline ODSL & Oregon Department of State Lands \\
\hline OWEB & Oregon Watershed Enhancement Board \\
\hline OWRD & Oregon Water Resources Department \\
\hline PCSRF & Pacific Coastal Salmon Recovery Fund \\
\hline POD & point of diversion \\
\hline RM & river mile \\
\hline SOW & Statement of Work \\
\hline TMDL & total maximum daily load \\
\hline UAFHP & Umatilla Anadromous Fisheries Habitat Project \\
\hline UBNPME & Umatilla Basin Natural Production Monitoring and Evaluation Project \\
\hline UBWC & Umatilla Basin Watershed Council \\
\hline USFWS & U.S. Fish and Wildlife Service \\
\hline USGS & United States Geological Survey \\
\hline UNF & Umatilla National Forest \\
\hline USDA & United States Department of Agriculture \\
\hline USFS & United States Forest Service \\
\hline UPR & Union Pacific Railroad \\
\hline WHIP & Wildlife Habitat Incentive Program \\
\hline
\end{tabular}




\section{Table of Contents}

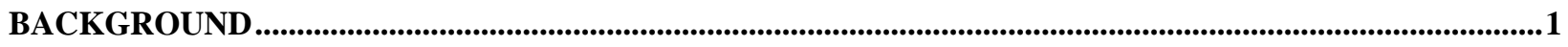

INTRODUCTION AND DESCRIPTION OF THE UMATILLA RIVER BASIN AND PROJECT AREAS ....4

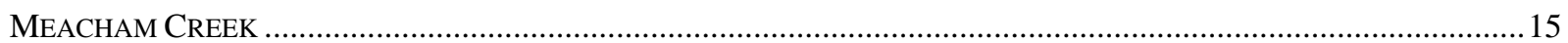

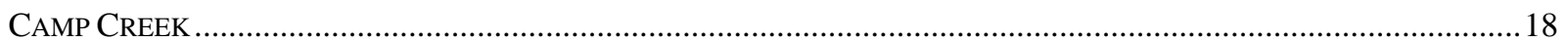

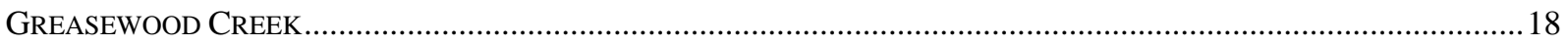

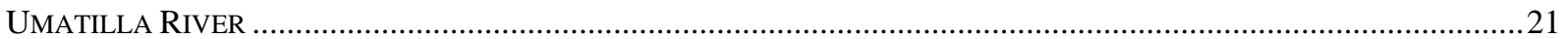

DESCRIPTION OF ESA LISTED AND SENSITIVE SPECIES IN THE UMATILLA RIVER BASIN

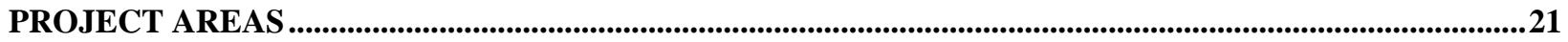

METHODS, RESULTS, AND DISCUSSION OF STATEMENT OF WORK DELIVERABLES......................24

A-C165: Complete ENVIRONMENTAL Consultation ProceSSES ....................................................................24

D189: REgional COORDINATION With OTHER AGENCIES IN PLANNING AND IMPLEMENTING HABITAT

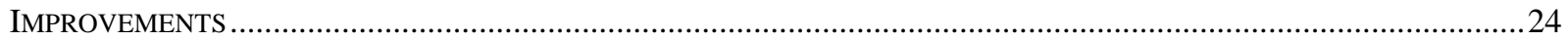

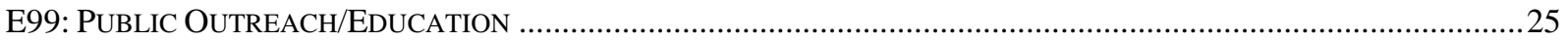

F157: COLLECT/GENERATE/VALIDATE FIELD AND LAB DATA AND ANALYZE INTERPRET DATA: COLLECT REDD

COUNTS/SUSPENDED SOLIDS/TURBIDITY, AND BENTHIC INVERTEBRATE DATA ……….......................................25

G162: ANALYZE/INTERPRET DATA: REDD COUNTS, SUSPENDED SOLIDS, \& INVERTEBRATE DATA ...........................30

H172: CONDUCT PRE-ACQUISITION ACTIVITIES: ACQUIRE CONSERVATION EASEMENTS FOR IMPROVEMENTS ON

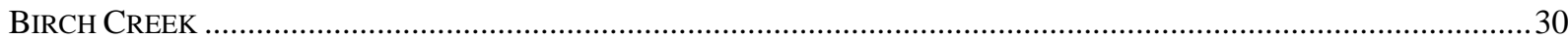

I175: PRoduce ENGINEERING DESIGN AND/OR SPECIFICATIONS: BIRCH/MEACHAM CREEK PROJECTS ....................30

J34: Develop Alternative Water Source: Dig Well as Alternative to Dam Diversion on Birch CreeK30

K34: Develop Alternative Water Source: Install Well for Alternative Livestock Water Source on

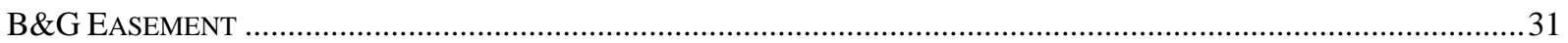

L149: INSTALL PIPELINE: INSTALL BURIED PVC IRRIGATION MAINLINES .........................................................31

M40: INSTALl FENCE: INSTALL FENCE ON BRoun EASEMENT, BIRCH CREEK....................................................... 31

N85: Remove/Breach DAM: Negotiate REMOVAl of BRoun Diversion DAM PASSAGE IMPEDIMENT ..............31

O85: Remove/Breach Dam: Negotiate the Removal of Peterson Diversion Dam Passage Impediment 31

P184: INSTALl Fish PASSAGE STRUCTURE: INSTALL Fish LADDER AT HOEFT DAM, WeST BiRCH CREEK .............32

Q184: INSTALl FISH PASSAGE STRUCTURE: INSTALL ROUGHENED CHANNEL CUNNINGHAM SHEEP COMPANY

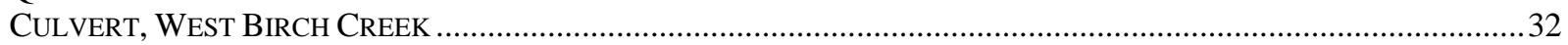

R29: INCREASE INSTREAM HABITAT COMPLEXITY: INSTALL RoCK CROSS VEINS IN MEACHAM CREEK .................32

S29: INCREASE InSTREAM HABITAT COMPLEXITY: Plan REMOVAl of LEVEeS, MEACHAM CREEK FloOdPlain 32

T47, U 47, W 53: Planting AND MaintenanCE OF VEgEtation, Control Noxious WeEdS ...........................32

V22: Maintain Vegetation Planted PreViously on Conservation Easements Properties .......................35

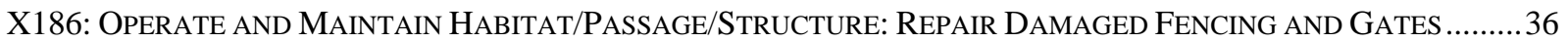

Y186: Operate AND MAINTAIN HABITAT/PASSAGE/STRUCTURE: CONDUCT OPERATION AND MAINTENANCE

ACTIVITIES ON INSTREAM IMPROVEMENT STRUCTURES - MONITORING AND EVALUATION .....................................36

Z122: PROVIDE TECHNICAL REVIEW OF PLANS AND PROPOSALS ..........................................................................3

AA174: Produce Plan: PreParation OF Six Project MANAgEMENT Plans .....................................................37

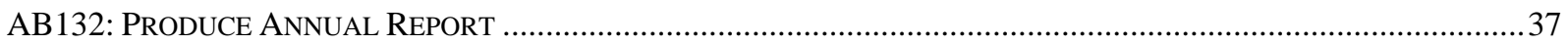

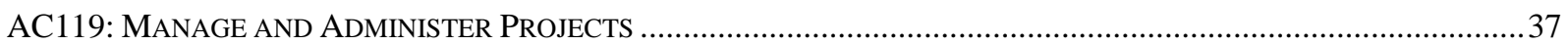

AD185: PRODUCE PISCES STATUS REPORTS AND PERIODIC STATUS REPORTS FOR BPA.........................................38

SELECTED FY2007 FISH HABITAT ENHANCEMENT AND RESTORATION ACTIVITIES .......................38

Fish Passage Barrier Rectification: Meacham Creek, Camp Creek, Greasewood Creek, West Birch

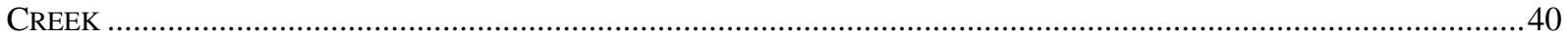

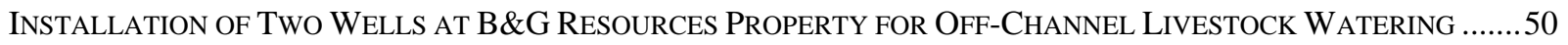

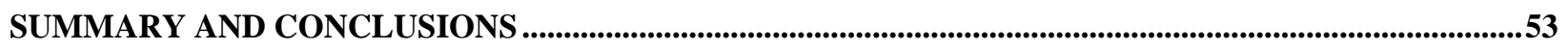

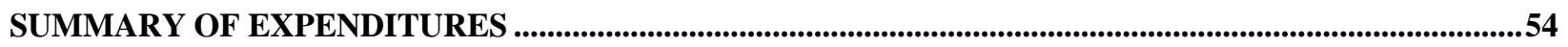

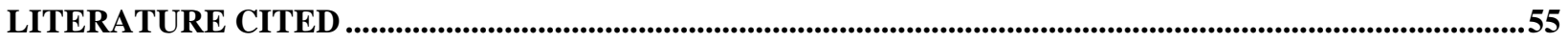




\section{List of Tables}

TABLE 1. USGS Flow Data: Umatilla River AND MeAcham CREeK ………...................................................10

TABLE 2. UPPER AND LOWER WATER TEMPERATURE TOLERANCES FOR SALMONIDS ..............................................26

TABLE 3. B\&G Resources OfF-ChANNEL LiVESTOCK WATERING Wells SPECIFICATIONS ...................................31

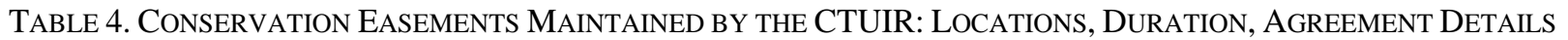
AND RECOMMENDED RENEWAL STATUS PROJECTIONS ……...........................................................................35

TABle 5. Actions AND Metrics Associated With the FY2007 UAFHP RESTORATION PROJECt ACtivities .......38

TABLE 6. MEACHAM WaTERSHEd Fish PASSAGE BARRIER DESCRIPTIONS FY2007 ..................................................40

\section{List of Figures}

FIgURE 1. UMATILLA RIVER BASIN

FigURE 2. UMATILLA River BASIN FY2007 UAFHP PROJECT SITES ......................................................................

Figure 3. Typical Reach OF THE Mid-Umatilla River Basin (RM 44) SHOWing THE VALLEy Form AND Degraded Fisheries Habitat Conditions: Disconnected Floodplain, PoOR Width to Depth Ratios, STREAMBANK EROSION, CHANNEL INCISION, NOXIOUS WEEDS, AND LACK OF ADEQUATE STREAM SHADING Due to NARROW RIPARIAN BELT WIDTH COMPRISED OF SECONDARY GROWTH AND LOCATED A SigNIFICANT DISTANCE FROM THE WETTED CHANNEL.

Figure 4. EDT Estimate OF CURRENT ABundance AND IMPACTS ON ADUlt STEELHEAD UnDER ThreE RESTORATION SCENARIOS (UMATILLA/Willow SubBASIN PLANNING TEAM 2004, P. 3-256) ..........................13

Figure 5. EDT Estimate of CURRENT PRODUCTIVITY AND IMPACTS ON THE STEELHEAD Population Under Three Restoration Scenarios (Umatilla/Willow SubBasin PlanNing TEAm 2004, P. 3-256)..............13

Figure 6. EDT Estimate of CURRENT ABUndANCE AND IMPACTS ON AdUlt SPRING CHINOOK UNDER Three RESTORATION SCENARIOS (UMATILLA/WILLOW SUBBASIN PLANNING TEAM 2004, P. 3-257) ..........................14

FiguRe 7. EDT Estimate OF CURRENT PRODUCTIVITY AND RESUlTS SHOWING THE IMPACTS ON AdULT SPRING

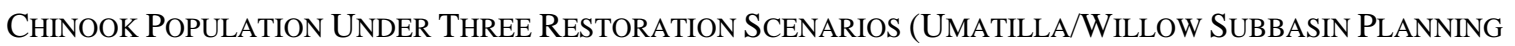
TEAM 2004, P. 3-257)

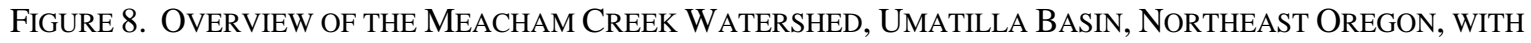
FY2007 PROJECT AREAS DENOTED BY LETTERS A-C..................................................................................15

FiguRE 9. 2005 PRe-IMPLEMENTATION HABITAT AND FISH SURVEY SAMPLING Sites (CTUIR 2005) .......................26

Figure 10. CTUIR Native Plant NuRSery Stool BedS ANd Containerized Plant STOCK .................................33

Figure 11. Weinke Dam Passage ReCtification Project Partnership With ODFW SHOWing WiLlOW PlANTINGS, BiRCH CREEK, RM 15.5 - DECEMBER 2007

Figure 12. Weinke Dam Passage Rectification Project Partnership With ODFW ShOWing Progress of Willow PlantingS, BirCH CREEK, RM 15.5 - July 2008

FiguRE 13. EXAMPLE OF LIVESTOCK EXCLUSION FENCING AT GREASEWOOD CREEK EASEMENT. CATTLE TRESPASS HAD CAUSED Significant Damage tO THE RiPARIAN AREA PRIOR to CTUIR REINFORCING THE FENCE IN

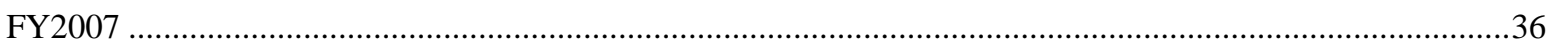

Figure 14. Photo Point Monitoring Methodology of Meacham CReEK LWD ConfiguRATions ....................39

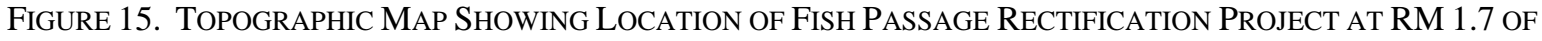
MEACHAM CREEK

Figure 16. TOPOGRAPHIC MAP SHOWING LOCATION OF Fish PASSAGE RECTIFICATION PROJECT AT RM 20.2 OF

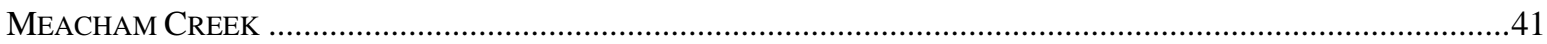

Figure 17. TOPOGRAPHIC MAP SHOWING LOCATION OF Fish PASSAGE RECTIFICATION PROJECT AT RM 0.3 OF CAMP CREEK

Figure 18. MEACHAM CREeK Fish PASSAge BARRIER RM 1.7, PRIOR to RECTIFICATION........................................43

Figure 19. MEACHAM CREeK Fish PASSAge BarRier RM 1.7, PoSt ReCTIFICATION ..............................................43

Figure 20. MEACHAM CREeK Fish PASSAge BARRIER, RM 20.2 PRIOR TO RECTIFICATION.......................................44

Figure 21. MEACHAM CREEK FISH PASSAGE BARRIER, RM 20.2 PoSt RECTIFICATION ............................................44

Figure 22. Meacham Creek RM 20.2 Construction of Upper Cross Vein SHOWing Site Isolation Method

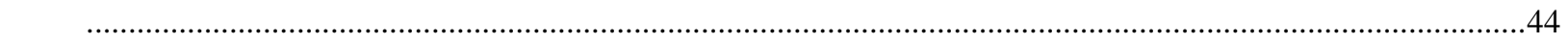

FIgURE 23. CAMP CREEK FISH PASSAGE BARRIER, RM 0.3 PRIOR TO RECTIFICATION ……........................................45

FiguRE 24. CAMP CREEK Fish PASSAGE BARRIER, RM 0.3 PoST RECTIFICATION ...................................................45

Figure 25. GREASEWOOD CREEK FISH PASSAGE BARRIER, RM 0.4 PRIOR TO RECTIFICATION ...................................46 


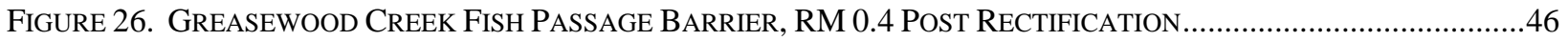

Figure 27. Blueprint Plan And Profile, Cunningham Bridge, West Birch Creek, RM 3.2 .......................47

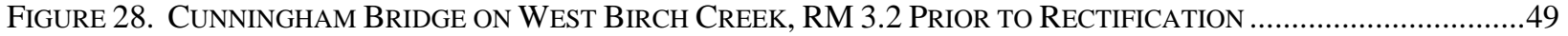

Figure 29. CunNingham BRIDGE ON WEST Birch CREeK, RM 3.2 Post RectificAtion...................................49

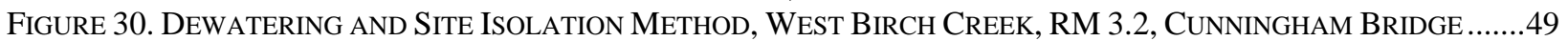

Figure 31. UMATILLA RivER RM 40, SHOWING SEVERELY INCISED CHANNEL AND BANK EROSION .......................51

FIGURE 32. WELL LOCATIONS AND CREP TRACTS, UMATILLA RIVER RM 40.............................................52

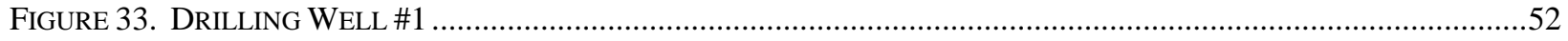

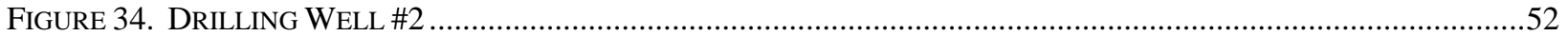




\section{BACKGROUND}

For tens of thousands of years, the ancestors of the Confederated Tribes of the Umatilla Indian Reservation (CTUIR) hunted and gathered food and fished various rivers and streams of the Pacific Northwest. They depended upon anadromous fish for subsistence and trade. CTUIR's right to fish in its historical fishing places was acknowledged in the Treaty of 1855 that stated: "the exclusive right of taking fish in the streams running through and bordering said reservation is hereby secured to said Indians, and at all other usual and accustomed stations..." (Treaty of 1855, Articles of Agreement, Article 1, page 3).

The indigenous people of the CTUIR still rely on natural resources from several watersheds located within areas of traditional use to provide them with a multitude of life essentials. Decreased salmonid abundance has significantly impacted the livlihood of the Tribal community and altered their way of life. It is the challenging duty of the CTUIR Umatilla Anadromous Fisheries Habitat Project (UAFHP) to restore and sustain healthy conditions of local watersheds to ensure they provide adequate quantities of sustainable natural resources to satisfy the CTUIR's needs and preserve opportunities for traditional ways of life.

The Bonneville Power Administration (BPA) funds the CTUIR and other Pacific Northwest Tribes to restore salmonid habitat as part of its mitigation activities due to the harmful effects and loss of habitat caused by the massive Columbia River hydroelectric dams. The CTUIR UAFHP, \#1987-100-01, funded by BPA through the Northwest Power Planning Council (NPPC) (renamed Northwest Power and Conservation Council in 2003 [NWPCC]) Fish and Wildlife Program, is an ongoing project initiated by CTUIR in 1987. The UAFHP is part of the broader effort by Columbia River Tribes to protect and restore salmonid populations and to preserve community traditions that honor and celebrate the CTUIR's ties to this vital food source. The CTUIR is guided in its habitat restoration activities by the Five-Year Action Plan for the Development and Maintenance of Habitat Improvement Projects in the Umatilla Subbasin: 2006-2010 For BPA-Funded Fish Habitat Improvement Programs sponsored by: Oregon Department of Fish and Wildlife (ODFW) and Confederated Tribes of the Umatilla Indian Reservation (CTUIR and ODFW 2006).

The goal of UAFHP is to protect, enhance, and restore salmonid habitat and abundance in the Umatilla River Basin. The project focuses on the mainstem Umatilla and tributaries that provide spawning, rearing, and migrational habitat for Middle Columbia River Basin Endangered Species Act (ESA) Listed summer steelhead and bull trout, as well as for spring chinook salmon, a preferred species of traiditonal importance to CTUIR. Habitat enhancement activities are designed to improve aquatic and riparian habitat resulting in an increase in viable populations of focal species and secondary species of fish and wildlife in the Umatilla River watershed. CTUIR is also engaged in activities to enhance habitat for bull trout, redband rainbow trout, Pacific lamprey, mountain whitefish, fall chinook and coho salmon.

During the 21-year project history, the CTUIR has helped administer and implement a number of fisheries habitat enhancement projects in the Umatilla River Basin. In fiscal year (FY) 2007, the CTUIR developed and implemented eight partnership habitat enhancement projects along Meacham Creek, Camp Creek, Greasewood Creek, Birch Creek, West Birch Creek and the mainstem Umatilla River. The CTUIR has developed effective interagency partnerships and is 
effectively working at the policy and project levels with various federal, state and county agencies and private landowners.

The UAFHP is an integral component of the Umatilla River Subbasin Salmon and Steelhead Production Plan (NPPC 1990) and is well integrated into the framework of the Umatilla Subbasin Plan (Umatilla/Willow Subbasin Planning Team 2005) established by the NWPCC to better coordinate habitat restoration work in the Umatilla River Basin. The CTUIR, ODFW, Natural Resource Conservation Service (NRCS), Umatilla Basin Watershed Council (UBWC), and other participating agencies and organizations have made significant progress towards restoring and protecting vital salmonid habitat in the basin.

\section{Noteworthy accomplishments for the CTUIR UAFHP during FY2007 included:}

- Fish passage improvements at five sites

- Planting 1275 saplings

- Developing eight water gaps for managing livestock access in the riparian and stream zone

- The installation of two off channel watering areas for livestock

- Construction of two miles of riparian fencing

- Seeding of 130 pounds of native grasses at West Birch Creek, River Mile (RM) 3.2 and Umatilla River, RM 40

- Bank sloping and riparian enhancement

- Conducting project maintenance activities

- Conducting various monitoring, evaluation, and maintenance activities on project areas and easement properties

- Maintaining 27 conservation easements on 23 properties and partnering with the NRCS Wildlife Habitat Incentives Program (WHIP) and Conservation Reserve Enhancement Program (CREP)

Subbasin planning teams utilized information from a variety of resource assessment sources to classify existing habitat status, determine limiting factors, and identify priority areas for restoration activities. A combination of both passive and active restoration strategies were then developed to address habitat deficiencies. Collection of aquatic habitat, geomorphology, water quality and fish abundance data is ongoing and utilized for optimizing adaptive restoration plans.

During the 2006 NWPCC project solicitation, the CTUIR developed a schedule of planned actions for Fiscal Years 2007-9 in cooperation with the ODFW. For FY2007, a complete project overview and technical approach is thoroughly described in the "Statement of Work Report 3.0.832.0 for the Umatilla Anadromous Fisheries Enhancement - CTUIR” project, which can be accessed from the following website at URL:

http://pisces.bpa.gov/release/reports/ReportViewer.aspx?RptName=SOWWorkElementsMilesto nesPublicVersion\&rs\%3aFormat=PDF\&psReferenceNumber=32047 (BPA 2008).

CTUIR secured funding for habitat improvements from a variety of sources in addition to the BPA, including Pacific Coastal Salmon Recovery Fund (PCSRF), Union Pacific Railroad (UPR) Mitigation, the Environmental Protection Agency (EPA), Oregon Department of Transportation (ODOT), Blue Mountain Habitat Restoration Council (BMHRC), and NRCS.

Although many project areas are in an early stage of recovery, establishment of conservation easements, construction of riparian exclosure fencing, development of off-channel water sources 
for livestock, revegetation efforts, and instream work, such as passage barrier rectification, channel reconstruction and large wood additions, have resulted in improving trends including:

- Improved stream channel stability with early succession dimension, pattern and profile

- Increased accessibility to suitable habitat conditions in headwater streams via passage rectification

- Decreased channel width:depth ratios, gradient, entrenchment and increased channel sinuosity, length, floodplain connection, and enhanced pool habitat

- Increased availability of instream habitat, including backwater and off-channel rearing areas

- Improved condition of riparian and wetland plant communities for fish and wildlife species

- Increased instream habitat complexity and diversity resulting in improved pool-riffle sequences associated with dynamically stable channel morphology.

Project results are reported in various BPA formats including Pisces status reports, project completion reports, and annual reports. The CTUIR maintains a complete database on project planning, proposals, permitting, implementation, and results through the completion of required project deliverables. For a complete list of reports submitted by the CTUIR's UAFHP dating to 1989, please consult the following website at URL:

http://www.efw.bpa.gov/integratedfwp/reportcenter.aspx and search publications, typing 1987100-01 in the project number box provided. Recent projects initiated in FY2006 and continuing in FY2007 are described in Umatilla River Basin Anadromous Fish Habitat Enhancement Project February 1, 2005-January 31, 2007 Annual Report (Document ID\# P102746) (CTUIR 2007), available online at: http://pisces.bpa.gov/release/documents/documentviewer.aspx?doc=P102746. 


\section{INTRODUCTION and DESCRIPTION OF THE UMATILLA RIVER BASIN and PROJECT AREAS}

\section{Umatilla River Basin}

The Umatilla River Basin is located in the northwest portion of the Blue Mountain Ecological Province, in northeast Oregon. The Umatilla River Basin comprises 1,465,600 acres of the 6,400,000 acres of ceded CTUIR land (CTUIR 1995) as identified by the Treaty of 1855 . Figure 1 illustrates the vicinity of the Umatilla River Basin within the Blue Mountain Province.

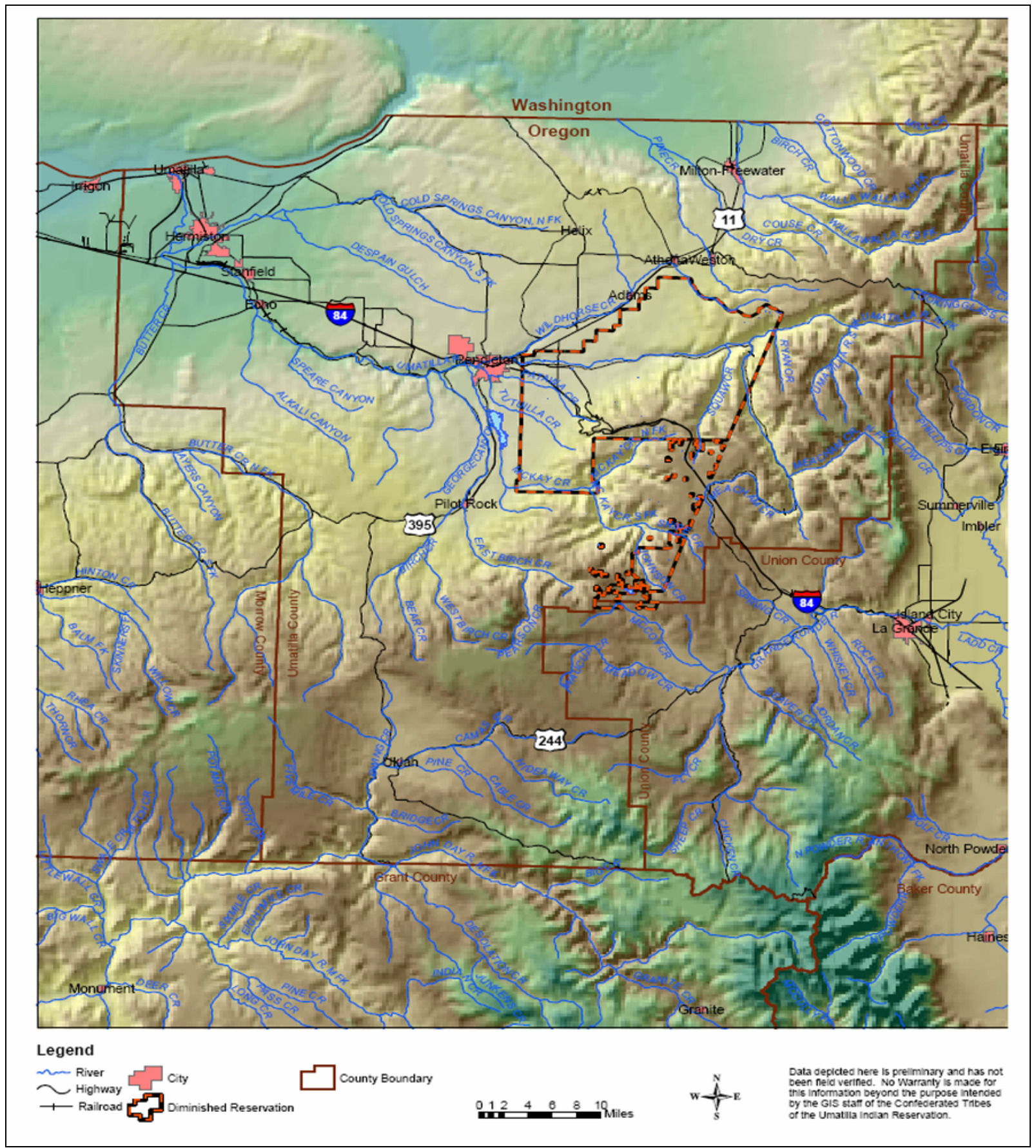

Figure 1. Umatilla River Basin 
High Priority Fish Habitat Restoration - Meacham Creek and Birch Creek Watersheds

The Umatilla/Willow Subbasin Plan (2004) identified Meacham Creek and Birch Creek as high priority watersheds for fish habitat restoration. The Meacham Creek Watershed has long been a primary focal point of the CTUIR effort to improve habitat conditions in the Umatilla Basin because of the location, size, historical significance and recovery potential. CTUIR has initiated restoration activities to address existing habitat deficiencies as part of a long term watershed restoration plan.

CTUIR and ODFW work together to co-manage and improve habitat in target areas in the Umatilla River Basin. We have adapted Table 2 (below) from the Five Year Action Plan for the Development and Maintenance of Habitat Improvement Projects in the Umatilla Subbasin (CTUIR and ODFW 2006) to show the priority target geographical areas (GA) for habitat improvement efforts and their associated applicable management strategies. CTUIR is the lead entity responsible to address habitat deficiencies in the following high priority target areas: (1) Birch Creek: RM 2.0 to Hoeft Road (RM 10.5); (2) East Birch Creek: Mouth to Humphrey Bridge (RM 4.0), and Westgate Canyon Ranch (Baker Property); (3) West Birch Creek: Mouth to Bear Creek (RM 5.0); (4) Meacham Creek: Mouth to Forks, RM 15.3 (including tributaries); and (5) Upper Umatilla River: Mission Bridge (RM 59.5) to Meacham Creek (RM 78.8). Recently, Birch Creek has been shifted from being solely managed by ODFW to co-managed with CTUIR as primary lead. ODFW is the lead entity responsible for the other GAs shown in the following table.

Table 2. Priority Target Areas for Habitat Improvement Efforts

\begin{tabular}{|c|c|c|c|c|c|c|}
\hline \multirow{2}{*}{\multicolumn{2}{|c|}{ GA No. and Location }} & \multicolumn{2}{|c|}{$\begin{array}{l}\text { EDT Ranking } \\
\text { for Protection }\end{array}$} & \multicolumn{2}{|c|}{$\begin{array}{l}\text { Priority Ranking } \\
\text { for Restoration }\end{array}$} & \multirow{2}{*}{$\begin{array}{c}\text { Applicable } \\
\text { Management } \\
\text { Strategies* }\end{array}$} \\
\hline & & $\begin{array}{l}\text { Summer } \\
\text { Steelhead }\end{array}$ & $\begin{array}{c}\text { Spring } \\
\text { Chinook }\end{array}$ & $\begin{array}{l}\text { Summer } \\
\text { Steelhead }\end{array}$ & $\begin{array}{l}\text { Spring } \\
\text { Chinook }\end{array}$ & \\
\hline \multicolumn{7}{|c|}{ HIGH PRIORITY TARGET AREAS } \\
\hline \multicolumn{7}{|c|}{ West Birch Creek and Tributary GAs } \\
\hline 15 & W. Birch - Bear Cr. to Top of Gorge & 14 & $\mathrm{~N} / \mathrm{A}$ & 5 & $\mathrm{~N} / \mathrm{A}$ & 1312111067859 \\
\hline 13 & W. Birch - Mth to Bear Cr. & N/A & N/A & 6 & N/A & 132312111067859 \\
\hline 14 & W. Birch - Bear $\mathrm{Cr}$. and tributaries & $\mathrm{N} / \mathrm{A}$ & $\mathrm{N} / \mathrm{A}$ & 12 & $\mathrm{~N} / \mathrm{A}$ & 10116859 \\
\hline 16 & W. Birch - Gorge to headwaters & 15 & N/A & $\mathrm{N} / \mathrm{A}$ & N/A & 1011 \\
\hline \multicolumn{7}{|c|}{ Birch Creek and East Birch Creek GAs } \\
\hline 12 & Birch Cr. - Mth to Forks & $\mathrm{N} / \mathrm{A}$ & $\mathrm{N} / \mathrm{A}$ & 1 & $\mathrm{~N} / \mathrm{A}$ & 1312111067895 \\
\hline 19 & E. Birch - Pearson Cr. to Headwaters & 5 & N/A & 9 & N/A & 10118659 \\
\hline 17 & E. Birch - Mth to California Gulch & $\mathrm{N} / \mathrm{A}$ & $\mathrm{N} / \mathrm{A}$ & 10 & $\mathrm{~N} / \mathrm{A}$ & 1011126782359 \\
\hline 18 & E. Birch - Calif. Gulch to Pearson Cr. & 11 & N/A & 11 & $\mathrm{~N} / \mathrm{A}$ & 10111267852359 \\
\hline \multicolumn{7}{|c|}{ Meacham Creek and Tributaries GAs } \\
\hline 33 & Meacham Cr. - Mth to N. Fork & $\mathrm{N} / \mathrm{A}$ & 3 & 4 & 2 & 71110612589 \\
\hline 35 & N. Fork Meacham Cr. - All & 4 & 2 & 8 & 5 & 10115689 \\
\hline 34 & Meacham Cr. - Tribs fr Mth to N. Frk. & $\mathrm{N} / \mathrm{A}$ & $\mathrm{N} / \mathrm{A}$ & 13 & $\mathrm{~N} / \mathrm{A}$ & 56781112 \\
\hline 38 & Meacham Cr. - 2 Mile to Headwaters & N/A & N/A & 15 & N/A & 106119512 \\
\hline \multicolumn{7}{|c|}{ Middle \& Upper Umatilla River Mainstem GAs } \\
\hline 28 & Umat. - Mission $\mathrm{Br}$. to Meacham $\mathrm{Cr}$. & N/A & 7 & 2 & 1 & 7121061158 \\
\hline 40 & Umat. - Meacham Cr. to Forks & 2 & 1 & 3 & 3 & 12106758119 \\
\hline
\end{tabular}

* Key to the Management Strategies Identified in the Subbasin Plan *

\begin{tabular}{|l|l|}
\hline \multicolumn{2}{|c|}{ Applicable Management Strategies } \\
\hline 2 - Purchase Water Rights form Willing Sellers & 9 - Address Roads in Riparian and Sensitive Areas \\
3 - Increase Water Conservation and Irrigation Efficiency & 10 - Increase Protective Status of Priority Habitats \\
5 - Large Wood/Boulder Structure Placement & 11 - Modify Detrimental Land Use Activities \\
6 - Fence Plant Riparian Zones & 12 - Restore Upstream/Headwater Attributes to Improve \\
7 - Modify Channel Flood-Plain Function & Downstream Conditions \\
8 - Construct Pool/Riffle - In-Stream Modifications & 13 - Increase Passage Efficiency \\
\hline
\end{tabular}

\begin{tabular}{|l|l|}
\hline \multicolumn{2}{|c|}{ Strategies Not Applicable (Management Level/Regulatory Strategy) } \\
\hline 1 - Phase I \& II Maintenance, Phase III Implementation & 14 - Maintain Passage Efficiency Through Ongoing O\&M \\
4 - Modify Zoning and Flood Control Planning & \\
\hline
\end{tabular}

Source: CTUIR and ODFW 2006. 
Applicable management strategies are presented in order of priority for each geographical area (GA) and are in accordance with the Final Umatilla Willow Subbasin Plan (Umatilla/Willow Subbasin Planning Team 2005). The red/bold text signifies management strategies recommended as priority within the GA.

Secondary Priority Fish Habitat Restoration - Greasewood Creek and Mid-Umatilla River Project implementation at locations not designated as of primary importance is ongoing and exemplifies CTUIR's philosophical commitment to holistic watershed health. At RM 0.4 on Greasewood Creek, a migratory fish passage barrier was rectified by partial dam removal, and at RM 0.5, a 2-mile long riparian fence to exclude livestock was constructed. Two wells were installed at RM 40 on the Umatilla River to provide off-channel cattle watering.

Figure 2 shows a map of FY2007 UAFHP project sites (indicated by letters A-H) where CTUIR conducted its restoration work in accordance with ODFW and CTUIR subbasin and action plans. A brief description of project site locations and restoration strategies are follow Figure 2. 


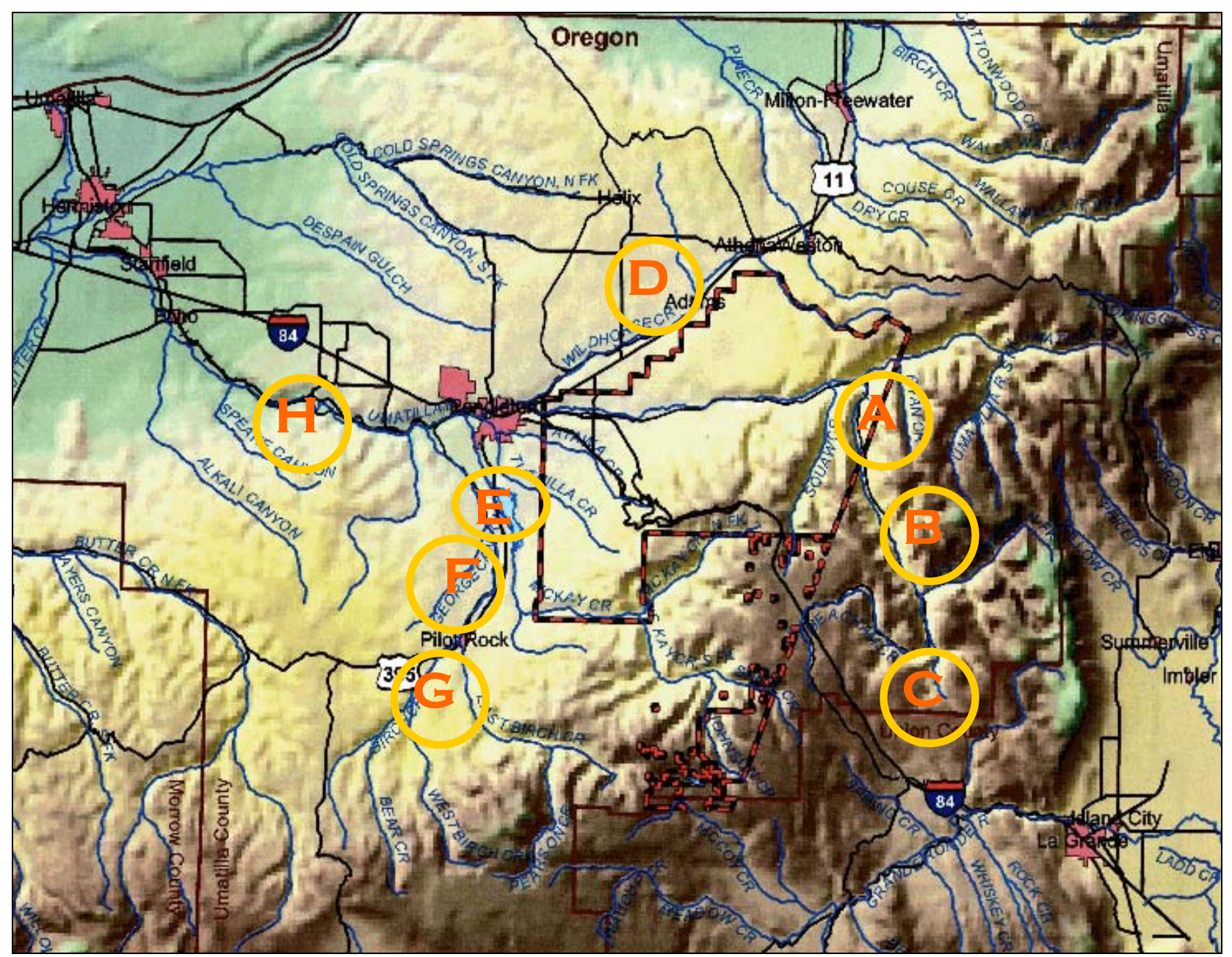

Figure 2. Umatilla River Basin FY2007 UAFHP Project Sites

A: Meacham Creek, RM 1.7Fish Passage Barrier Removed, Riparian Plantings.

\section{B: Camp Creek, RM 0.3-}

Fish Passage Barrier Removed, Grade Control Structure With Rootwads, Riparian Plantings.

C: Meacham Creek, RM 20.2Fish Passage Barrier Removed, Grade Control Structures With Rootwads, Riparian Plantings.

\section{D: Greasewood Creek, RM 0.4-}

Fish Passage Barrier Removed, Riparian Fence Constructed With 8 Water Gaps for managed livestock watering.

\section{E: Birch Creek, RM 10.3- \\ Riparian Plantings.}

\section{F: Birch Creek, RM 15.5-}

Riparian Plantings associated with ODFW Fish Passage Barrier Removal Project.

\section{G: Umatilla River, RM 40-} 2 Wells Constructed for Off Channel Livestock Watering, Riparian Plantings.

H: W. Birch Creek, RM 3.2Fish Passage Barrier Removed, Bank Sloping, Riparian Plantings. 


\section{Geology and Vegetation}

The Umatilla River Basin can be roughly divided near the city of Pendleton, Oregon (OR) (RM 53) into two physiographic regions. The lower river, west of Pendleton, has cut a low valley into a broad upland plain called the Deschutes-Umatilla Plateau. Parent geologic materials of the plain are dominated by multiple layers of middle Miocene basalt flows, specifically, the Wanapum and Grand Ronde Basalts, originating 14 to 17 million years ago. Basalt bedrock outcroppings are common in the river channel and act as hydraulic controls that delay the deepening of the river channel and valley floor. Pleistocene and Holocene loess, alluvial, and glaciofluvial deposits are located on top of the Miocene basalts (Walker and MacLeod 1991; USGS 2008). Currently, vegetation on the broad Deschutes-Umatilla Plateau is primarily comprised of dryland crops and sagebrush-grass communities. Annual precipitation averages 10 inches/year (in./yr) near the confluence with the Columbia River to 50 in./yr in the headwaters (Taylor 1993).

The region east of Pendleton is dominated by the Blue Mountain foot hills and the Blue Mountains. The Blue Mountains are accreted terranes (Alt and Hyndman 1995) that underwent lifting, faulting and folding of volcanic, sedimentary and metamorphic rock from 15-6 million years ago. The middle Miocene basalts of the lower river are also the dominant parent materials in the headwaters. The river and streams have cut steep-sided canyons into the layers of rock that form the higher elevations of the Blue Mountains. Exposed basalt outcrops fracture into blocks and plates while the unexposed layers remain fairly impervious to water (Walker and MacLeod 1991). The combination of steep canyon walls and impervious bedrock lends to poor ground water recharge (NPPC 1990). Vegetation distribution patterns upstream of Pendleton are typical for the Blue Mountains. Grasses and small shrubs dominate the drier, south facing slopes. Conifers dominate the north facing slopes, higher elevations, and moderately wet areas.

Historically throughout the Umatilla Basin, deciduous trees were abundant in riparian areas on the valley floor; however, land use practices over the last hundred years have cleared most of these areas for irrigated agricultural and urban uses. Three-quarters of the Umatilla River has been constrained by levees, and consequently, approximately $70 \%$ of riparian areas in the Umatilla River Basin were reported to be in need of improvement. Riparian vegetation on the mainstem Umatilla River and many tributaries is in poor condition. Approximately $70 \%$ of 422 miles inventoried were identified as needing riparian improvements (Umatilla/Willow Subbasin Planning Team 2004). In the lower Subbasin, losses of riparian vegetation are particularly high; one study estimated those losses at greater than 95\% as compared to presettlement conditions (c. 1850) (Umatilla/Willow Subbasin Planning Team 2004). Figure 3 illustrates several typical degraded conditions found along the Umatilla River and its tributaries. 


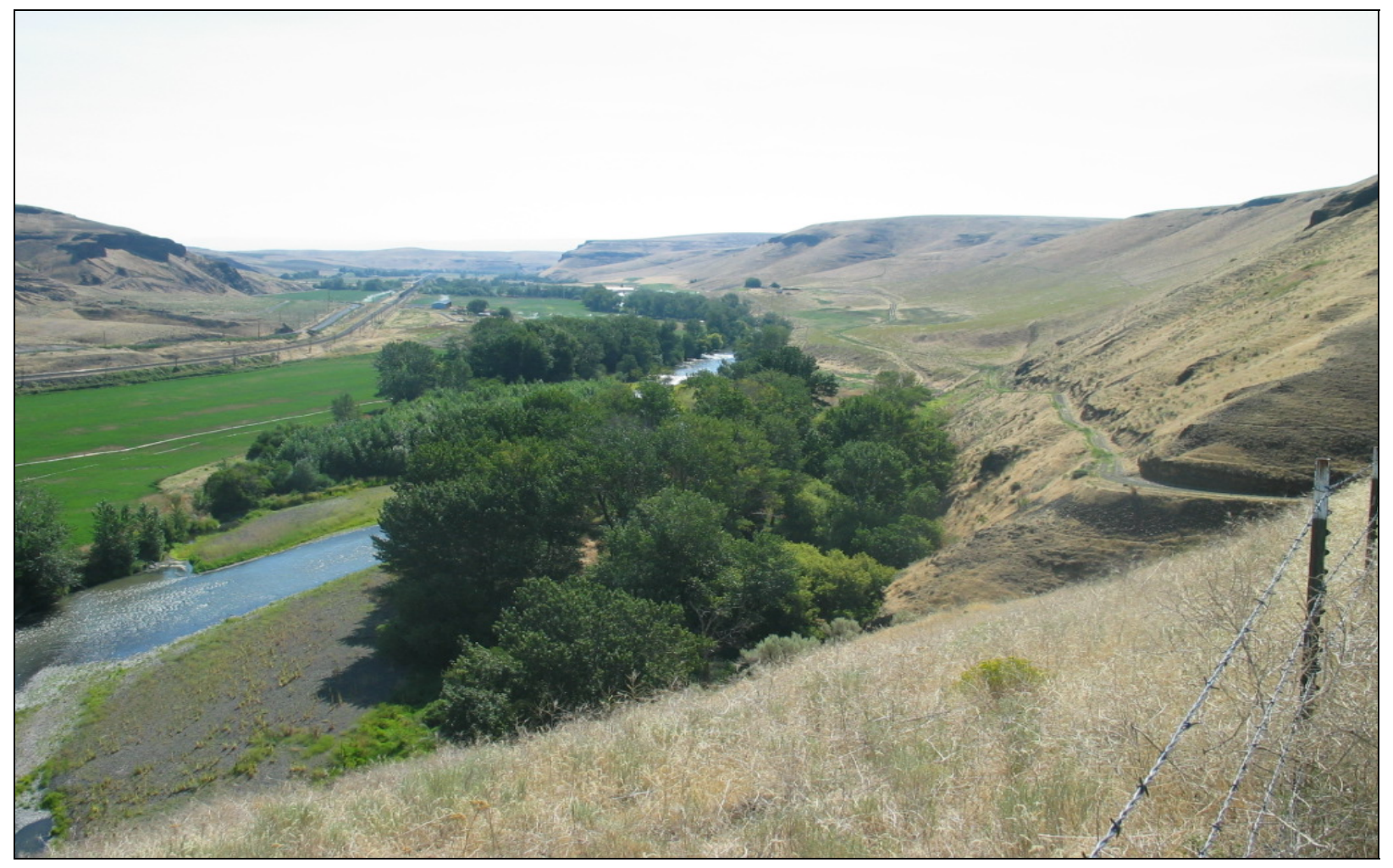

Figure 3. Typical Reach of the Mid-Umatilla River Basin (RM 44) Showing the Valley Form and Degraded Fisheries Habitat Conditions: Disconnected Floodplain, Poor Width to Depth Ratios, Streambank Erosion, Channel Incision, Noxious Weeds, and Lack of Adequate Stream Shading Due to Narrow Riparian Belt Width Comprised of Secondary Growth and Located a Significant Distance from the Wetted Channel.

\section{Hydrology}

U.S. Geological Service flow data from 1995-2008 at Gibbon, OR (RM 78.5) and the West Reservation Boundary, Umatilla River (RM 56.1) show unstable, flashy hydrograph patterns and extreme low and high flow episodes (Table 1). The Umatilla River hydrographs exhibit tall peaks indicative of high flows during high rain, snowmelt, and runoff events in the spring and early winter, but severe drops in flow during the semi arid summer months, when it is not uncommon to have reaches of major tributaries devoid of flows for months at a time. This phenomenon results from the regional geological characteristics and arid climate, but is also influenced by the poor health of the watershed.

This hydrologic effect is less pronounced in the relatively pristine North Fork Umatilla Wilderness Area, apparently because of minimal human disturbance, higher elevations, developed soils, and expansive riparian areas featuring large woody debris and climax plant communities and therefore is generally perceived as a "control” reach. 
Table 1. USGS Flow Data: Umatilla River and Meacham Creek

\begin{tabular}{|c|c|c|c|c|c|}
\hline Station & Location & $\begin{array}{l}\text { Drainage } \\
\text { Area }\end{array}$ & Gage & Remarks & Extremes for Period of Record \\
\hline $\begin{array}{l}\mathbf{1 4 0 2 0 8 5 0} \\
\text { Umatilla } \\
\text { River at West } \\
\text { Reservation } \\
\text { Boundary } \\
\text { (RM 56.1) }\end{array}$ & $\begin{array}{l}\text { Lat } 45^{\circ} 40^{\prime} 18^{\prime \prime} \text { Long } \\
118^{\circ} 44^{\prime} 08 " \text {, in NE 1/4 } \\
\text { NW 1/4 sec 7, T.2.N, } \\
\text { R.33 E, Umatilla } \\
\text { County, Hydrologic } \\
\text { Unit } 17070103 \text {, on left } \\
\text { bank, } 1.6 \text { miles above } \\
\text { Wildhorse Creek, } 2.5 \\
\text { miles east of Post } \\
\text { Office in Pendleton, } \\
\text { and at mile 58.3. }\end{array}$ & $440 \mathrm{mi}^{2}$ & $\begin{array}{l}\text { Water stage } \\
\text { recorder. } \\
\text { Elevation } \\
\text { of gage is } \\
1,130 \mathrm{ft} \\
\text { above } \\
\text { NGVD of } \\
\text { 1929, from } \\
\text { topographic } \\
\text { map. }\end{array}$ & $\begin{array}{l}\text { No known } \\
\text { regulation. } \\
\text { Many diversions } \\
\text { for irrigation } \\
\text { upstream from } \\
\text { station. Satellite } \\
\text { telemeter at } \\
\text { station. }\end{array}$ & $\begin{array}{l}\text { Period of Record: } 1995 \text { to current year: } \\
\text { Maximum discharge, } 12,700 \mathrm{ft}^{3} / \mathrm{s} \\
\text { Feb. 9, 1996, gage height, } \\
11.64 \mathrm{ft} \text {; minimum discharge, } 25 \mathrm{ft}^{3} / \mathrm{s} \\
\text { Aug. 19, } 2003 \text {. }\end{array}$ \\
\hline $\begin{array}{l}\mathbf{1 4 0 2 0 3 0 0} \\
\text { Meacham } \\
\text { Creek at } \\
\text { Gibbon, OR } \\
\text { (RM 78.5) }\end{array}$ & $\begin{array}{l}\text { Lat } 45^{\circ} 41 ' 20 " \text {, long } \\
118^{\circ} 21 ' 20 " \text {, in SE } 1 / 4 \\
\text { SE } 1 / 4 \text { sec.31, T.3. N., } \\
\text { R.36 E., Umatilla } \\
\text { County, Hydrologic } \\
\text { Unit } 17070103 \text {, on left } \\
\text { bank } 250 \mathrm{ft} \\
\text { downstream from } \\
\text { Union Pacific railroad } \\
\text { bridge, } 0.9 \text { mile } \\
\text { southeast of Gibbon, } \\
\text { and at mile } 1.4 .\end{array}$ & $176 \mathrm{mi}^{2}$ & $\begin{array}{l}\text { Water stage } \\
\text { recorder. } \\
\text { Datum of } \\
\text { gage is } \\
1,803.05 \mathrm{ft} \\
\text { above } \\
\text { NGVD of } \\
1929 .\end{array}$ & $\begin{array}{l}\text { No regulation or } \\
\text { diversion } \\
\text { upstream from } \\
\text { station. }\end{array}$ & $\begin{array}{l}\text { Period of Record: August } 1975 \text { to current } \\
\text { year: } \\
\text { Maximum discharge, 5,930 } \mathrm{ft}^{3} / \mathrm{s} \\
\text { Nov. 28, 1995, gage height, } \\
7.67 \mathrm{ft} \text {, from rating curve extended above } \\
4,600 \mathrm{ft}^{3} / \mathrm{s} \text {; maximum gage height, } 8.16 \mathrm{ft} \text {, } \\
\text { from floodmark; minimum discharge, } \\
6.6 \mathrm{ft}^{3} / \mathrm{s} \text { Aug. 29, } 1984 \text {. } \\
\text { Extremes Outside Period of Record: Flood of } \\
\text { Jan. } 25,1975 \text {, reached a stage of } 7.21 \mathrm{ft} \text {, from } \\
\text { floodmark, discharge, about } 8,200 \mathrm{ft}^{3} / \mathrm{s} \text {. }\end{array}$ \\
\hline
\end{tabular}

Source: U.S. Geological Survey Water Data Website, as accessed November 19, 2008 at URL:

http://waterdata.usgs.gov/nwis/uv/?site_no=14020850\&agency_cd=USGS and http://waterdata.usgs.gov/nwis/uv/?site_no=14020300\&agency_cd=USGS 


\section{Anthropogenic Effects on Salmonid Habitat}

The Umatilla River Basin historically supported viable and harvestable populations of spring/summer and fall chinook salmon (Oncorhynchus tshawytscha), coho salmon (O. kisutch), sockeye salmon (O. nerka), summer steelhead (O. mykiss), Pacific lamprey (Entosphenus tridentatus), bull trout (Salvelinus confluentus), rainbow/redband (O. mykiss sp.), and mountain whitefish (Prosopium williamsoni). Human-caused alterations have negatively impacted the watershed and caused significant reductions of endemic salmonid populations. Beginning in the late 1800s, fish populations started to decline due to habitat degradation; sockeye and coho were extirpated in the early 1900s. Irrigation and agricultural development throughout the basin in the early 1900s is believed to be the primary cause of the decline of steelhead and the extinction of salmon. Since the completion of the Treaty of 1855, aquatic and riparian habitats have been degraded through irrigation diversions, water extractions, channelization, livestock grazing, logging, agriculture and urban development (Umatilla/Willow Subbasin Planning Team 2004). Subsequently, the abundance of chinook, steelhead, bull trout, and other fish species has also been dramatically reduced. With declining fish populations, Tribal governments, federal, state and international agencies were obligated to eliminate or significantly reduce subsistence and sport fisheries by the mid 1970s. The Federal government listed Columbia River spring chinook salmon, summer steelhead, and bull trout as threatened species under the ESA in 1973, 1992, 1997, and 1998, respectively.

The following species listed under the ESA currently occur in the Umatilla River Basin: Columbia River bull trout Critical Habitat (designated), Columbia River bull trout (threatened), and Mid Columbia River steelhead (threatened). In the mid 1980s, a successful, hatchery-based salmonid reintroduction effort for the Umatilla River was instituted using neighboring strains of various salmonid species. Although hatchery programs currently support subsistence and restricted sport fishing opportunities for steelhead and chinook salmon, there remains significant need to re-build viable, harvestable, and sustainable fish stocks throughout the basin.

Modern human activities have loaded the Umatilla River with agricultural fertilizers, sewage, pesticides, and suspended sediments, as well as urban and industrial pollution (CTUIR 2007). The Oregon Department of Environmental Quality (ODEQ) listed the Umatilla River Basin on the State's list of water quality limited water bodies' 303(d) list. (Please see the ODEQ website at URL http://www.deq.state.or.us/wq/assessment/rpt0406/results.asp for details.) A Total Maximum Daily Load (TMDL) was also written for waters within reservation boundaries (CTUIR 2005) that, in combination with CTUIR's habitat enhancement work, should lead to water quality improvements over the long term. (Please see http://yosemite.epa.gov/R10/WATER.NSF/TMDLs/Approved+TMDLs\#OR, select “Oregon”, and navigate to "Umatilla Tribal TMDL" for a copy of this report.)

Throughout much of the watershed, maximum water temperatures exceed lethal limits for bull trout and approach lethal limits for chinook salmon and rainbow/steelhead trout. The high stream temperatures potentially limit carrying capacity, adversely affect fish fitness, and should be considered as a primary factor limiting salmonid production in the watershed. CTUIR's UAFHP is currently taking steps to address water quality issues through its habitat restoration activities. 


\section{Habitat Protection/Restoration Activities}

Habitat protection and restoration needs in the basin have been recognized in numerous reviews, planning processes, and reports (CTUIR 1993; CTUIR 2000; Umatilla/Willow Subbasin Planning Team 2004; 2005). The National Marine Fisheries Service (NMFS) has recently restarted the recovery planning effort for chinook salmon and steelhead and tributary habitat restoration. The National Research Council (NRC) (1996) notes the importance of protecting and rehabilitating freshwater habitat as part of salmon recovery and specifically notes the importance of riparian areas. This body recommended that habitat reclamation or enhancement should emphasize rehabilitation of ecological processes and function (NRC 1996). The United States Fish and Wildlife Service (USFWS) draft bull trout recovery plan (USFWS 2002) also recognized the importance of habitat protection and restoration, specifically noting the need to improve water quality, reduce or eliminate fish passage barriers, and restore impaired instream and riparian habitat. Pre-project implementation aquatic habitat inventory surveys conducted by CTUIR revealed that habitat quality ranked poor in $85 \%$ of areas surveyed and fair in $15 \%$ in the Umatilla River. Flow quantity, water quality, passage, and in-stream channel complexity were identified as key limiting factors.

The Draft Umatilla Willow Subbasin Plan (Umatilla/Willow Subbasin Planning Team 2004) determined that the limiting factors could be addressed through habitat restoration and implementation ("Phase III") of the Umatilla Basin Project. Three restoration scenarios were proposed based on the results of the Ecosystem Diagnostic Treatment (EDT) model: (1) Habitat restoration of the top priority geographic areas singly plus the implementation of Phase III of the Umatilla Basin Project; (2) Habitat restoration of the top 19 geographic areas plus implementation of Phase III; and (3) Habitat restoration of the top 19 geographic areas with no implementation of Phase III. The EDT abundance and productivity results for steelhead and spring chinook are shown graphically in Figures 4-7.

Not surprisingly, these results suggested that the greatest amount of action (restoring all 19 geographic areas and implementing Phase III flow increases) has the greatest impact on steelhead and chinook salmon productivity and abundance. The Final Umatilla Willow Subbasin Plan (2005) recommended habitat restoration and implementation ("Phase III") of the Umatilla Basin Project as the means to address the important limiting factors. Implementation of Phase III will involve increased instream flows in the Umatilla River mainstem from Thornhollow (RM 73.5) to the mouth. In accordance with the 2006 NPCC solicitation outline, the FY2007 CTUIR UAFHP focused its restoration activities primarily on the Meacham and Birch Creek watersheds. However, project development continues to be prevalent throughout the basin when feasible opportunities to succeed arise. 


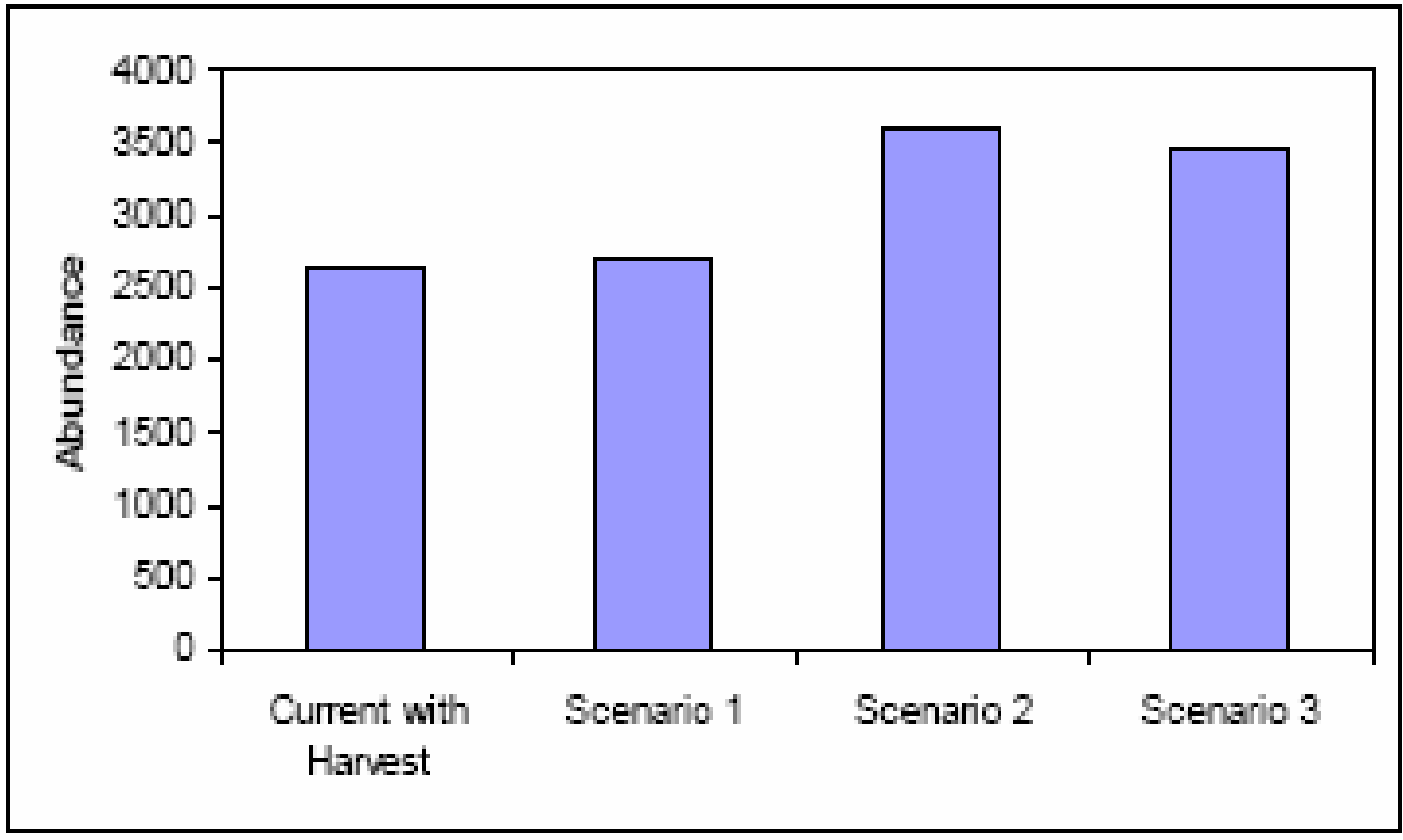

Figure 4. EDT Estimate of Current Abundance and Impacts on Adult Steelhead Under Three Restoration Scenarios (Umatilla/Willow Subbasin Planning Team 2004, p. 3-256)

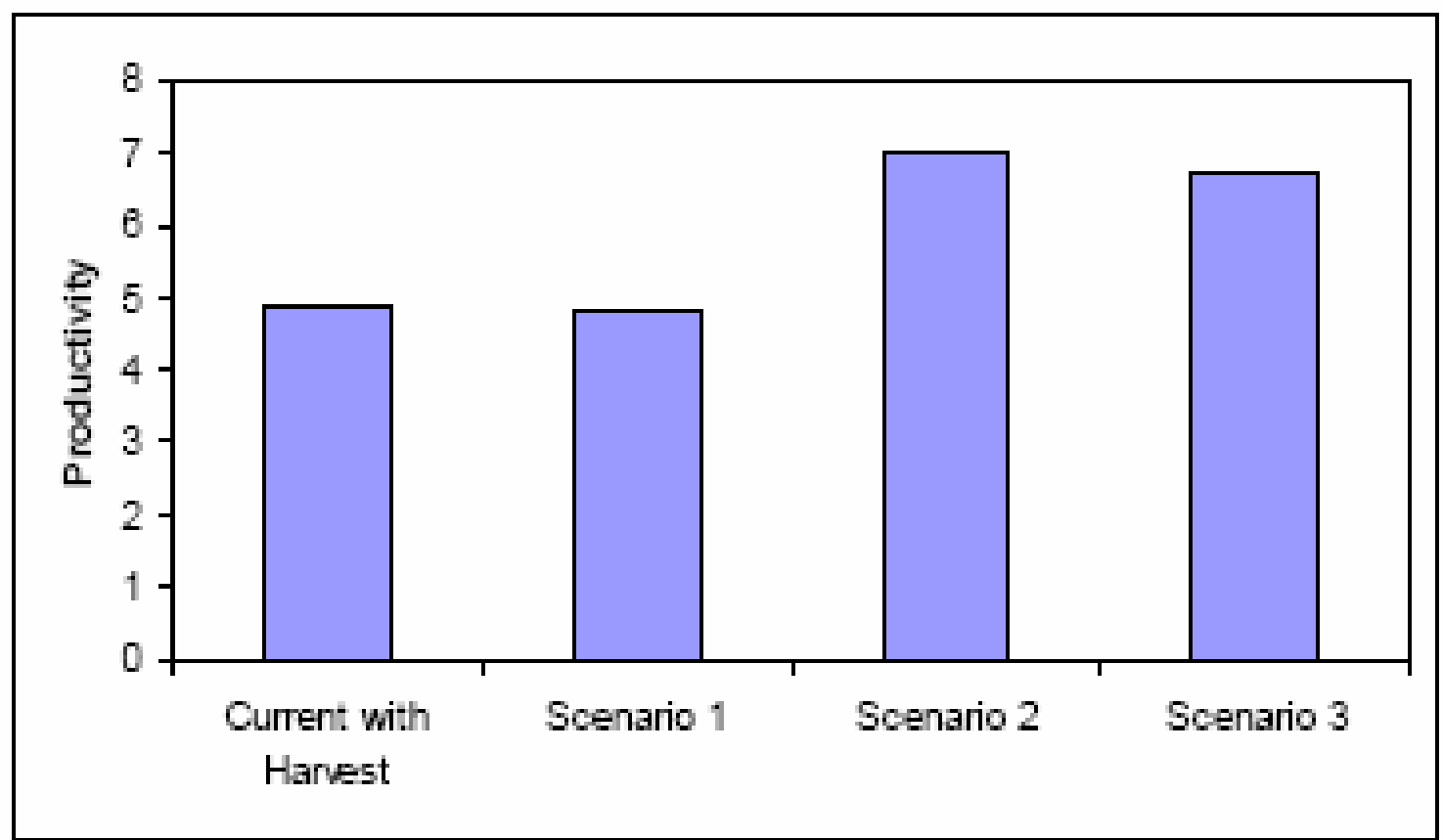

Figure 5. EDT Estimate of Current Productivity and Impacts on the Steelhead Population Under Three Restoration Scenarios (Umatilla/Willow Subbasin Planning Team 2004, p. 3-256) 


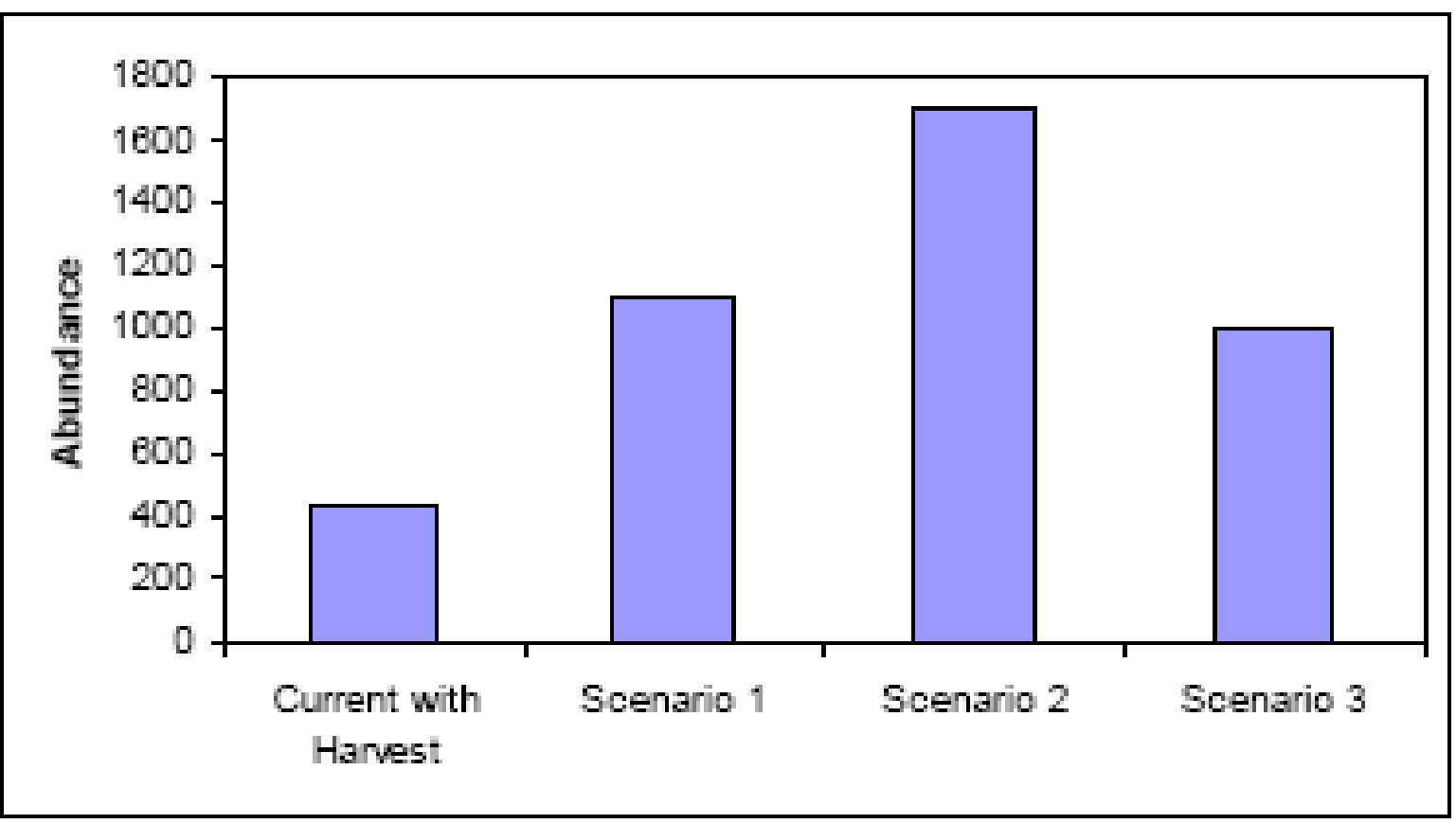

Figure 6. EDT Estimate of Current Abundance and Impacts on Adult Spring Chinook Under Three Restoration Scenarios (Umatilla/Willow Subbasin Planning Team 2004, p. 3257)

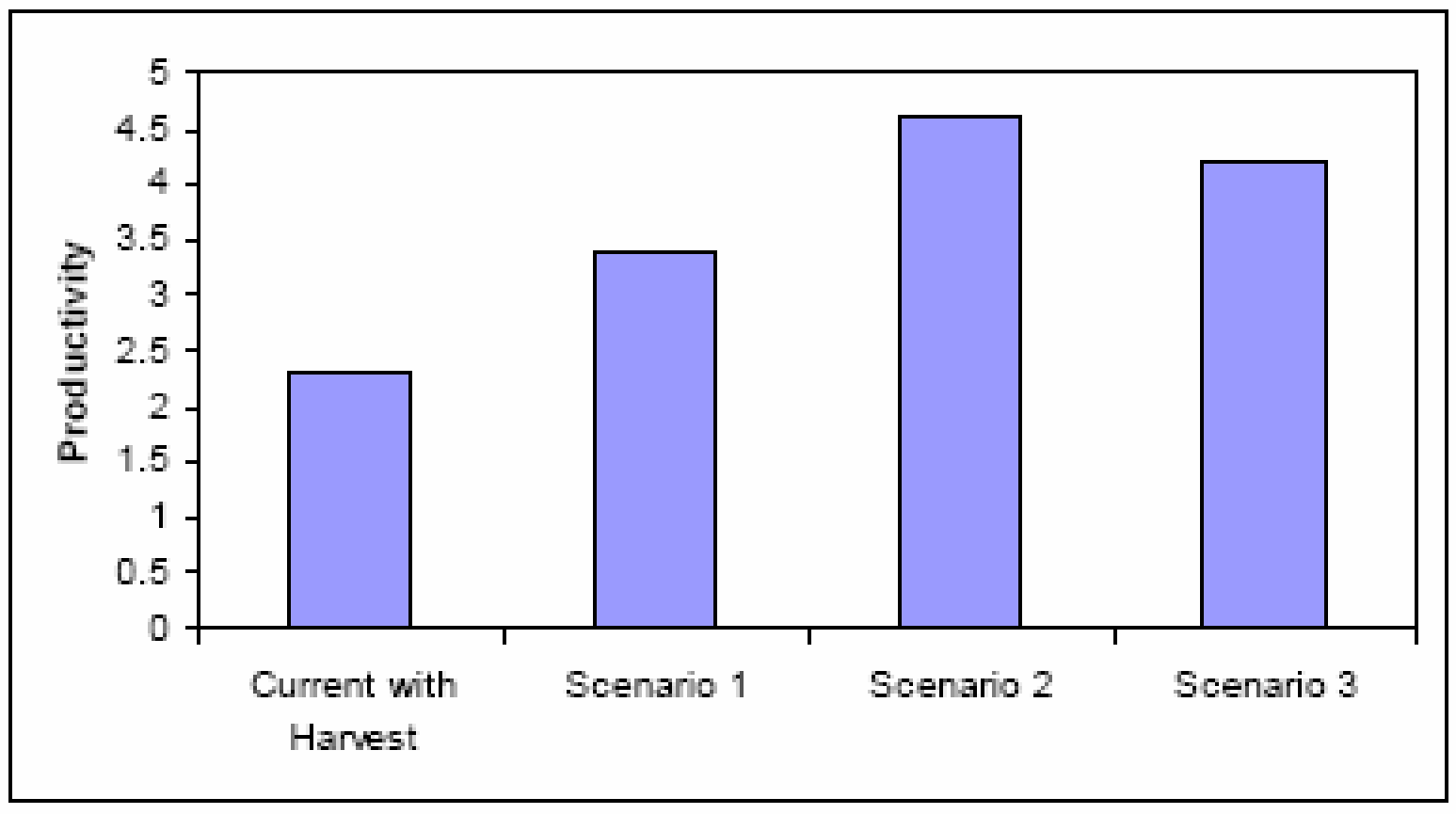

Figure 7. EDT Estimate of Current Productivity and Results Showing the Impacts on Adult Spring Chinook Population Under Three Restoration Scenarios (Umatilla/Willow Subbasin Planning Team 2004, p. 3-257) 
The following paragraphs describe specific areas where FY2007 were implemented by CTUIR's UAFHP.

\section{Meacham Creek \\ Description of Watershed}

The 114,000 acre Meacham Creek Watershed (Figure 8) is located in northeast OR, on the west slope of the Blue Mountains, 23 miles east of the city of Pendleton, OR. The headwaters originate near the towns of Meacham and Kamela, OR, near Salmon Back Ridge. Meacham Creek is a 37-mile long major tributary of the Umatilla River that enters near RM 79. Although intermittent in several reaches, it contributes slightly more than half of the summer flow to the mainstem Umatilla River at the confluence. Data from CTUIR shows that Meacham Creek runs $2-3{ }^{\circ} \mathrm{C}$ warmer $\left(16{ }^{\circ} \mathrm{C}\left[60.8{ }^{\circ} \mathrm{F}\right]\right.$ vs. $\left.13.5^{\circ} \mathrm{C}\left[56.3^{\circ} \mathrm{F}\right]\right)$ during the summer than the Umatilla River at the confluence.

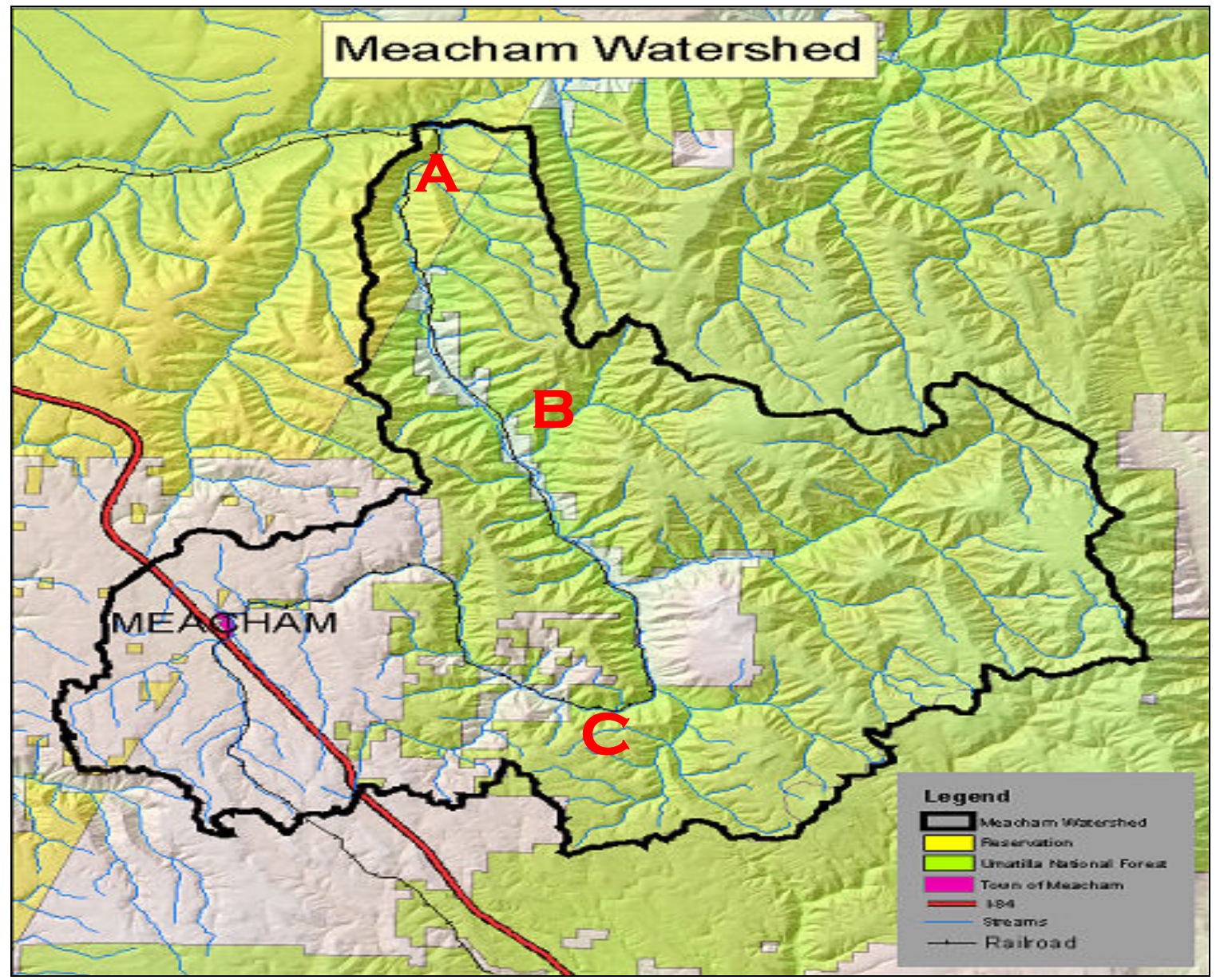

Figure 8. Overview of the Meacham Creek Watershed, Umatilla Basin, Northeast Oregon, with FY2007 Project Areas denoted by letters A-C.

Key to Project Sites, Locations and Strategies:

A: Meacham Creek RM 1.7 - Removed Cabled Boulders to Rectify Fish Passage Concern, Riparian Plantings.

\section{B: Camp Creek RM 0.3 - Fish Barrier Rectification, Partial Dam Removal, Grade Control Structure with} Rootwads, Riparian Plantings.

C: Meacham Creek RM 20.2 - Fish Passage Barrier Rectification, Partial Dam Removal, Riparian Plantings, Grade Control Structures with Rootwads. 
The topography of the Meacham Watershed is typical of the Blue Mountain foothills, with broad flat ridges bisected by moderately steep, constraining canyons with a variety of aspects. The valley floor is generally comprised of multiple terraces alternating with moderately steep hillslopes located adjacent to the creek. Elevations range from approximately 1,850 feet above sea level near Project Site A, RM 1.7, to approximately 2,850 feet at the uppermost barrier, Project Site C, near RM 20.2. In the lower half of the basin, the watershed is characterized by having a broad valley floor, averaging 10.7 times as wide as the active channel. The upper half consists of much steeper and closely orientated hillslopes that encroach upon the channel and contribute increasing proportions of bedrock into the channel and bank composition. The typical channel morphology is most representative of a Rosgen "C" type classification (e.g., slightly entrenched, meandering, alluvial channels that occur on gentle gradients in broad valleys) (Rosgen 1996) in the lower half of the basin; in the upper basin, the channel becomes increasingly constrained due to natural and human-made conditions.

\section{Hydrology}

The USGS maintains a gauging station operated in cooperation with the CTUIR at Gibbon, OR (RM 78.5). The drainage area covered is 176 square miles $\left(\mathrm{mi}^{2}\right)$. Maximum flows peak at 8,800 cubic feet per second (cfs), while minimums of $7 \mathrm{cfs}$ constitute summer base flows (Table 1). Several vast dry channel reaches are located intermittently throughout Meacham Creek in the summer months. It has been theorized that substantial fish displacement, stranding, and mortality occurs in the system due to these hydrological conditions.

\section{Plant Communities}

Plant communities in the Meacham Watershed exhibit a grass-timber mosaic characteristic, typical in the Blue Mountains. North-facing slopes and the riparian corridor support second growth timber. Grasslands are more common on south-facing slopes. In the riparian areas, cottonwoods and conifers (12-20 in. diameter breast height [dbh]) are dominant, various shrubs comprise the second-story growth, and tertiary growth consists of grasses. Riparian shrub communities generally consist of black hawthorn, Himalayan blackberry, willow, and to a lesser extent, oceanspray, various rose species, elderberry, and common snowberry. Other habitat types include upland shrub, predominantly mallow ninebark/common snowberry and common snowberry/rose plant associations, located in stream or draw bottoms.

\section{Anthropogenic Impacts}

The Meacham Watershed is of historical significance to Native American people of the area because of its traditional hunting, fishing and gathering opportunities. There are various ancient sites of cultural significance located adjacent to the Meacham waterways. The primary impacts to Meacham Creek are associated with the adjacent UPR railway, built in the early 1900s at close proximity to the mainstem of Meacham Creek for the majority of its 37 river miles. Extensive diking, channel relocation or constrainment, and alteration of the vegetative component are impacts associated with construction and maintenance of railway operations. Many of the large trees in the Meacham watershed were likely removed to fuel steam locomotives during the early days of railroad and to supply the needs of a sawmill formerly located near RM 2 of the North Fork of Meacham Creek (Andrus and Middel 2003). A significant secondary impact to Meacham Creek is the presence of livestock in the riparian area and stream zone, where moderate to heavy grazing pressure occurs. 
The current property ownership profile of Meacham Creek and watershed shows a mixture of public, private, and Tribal ownership. Management of the resources in the watershed is controlled by various Tribal, Federal, private and corporate interests. Much effort is devoted to planning and promoting cooperative participation in the restoration process by the various entities. Project scoping and educational outreach continues to be an important tool in regard to forging mutually beneficial relationships and coordinating restoration efforts among all land managers in the basin.

In limited areas, hunting and fishing opportunities are available to tribal and non-tribal participants, but much of the basin is somewhat restricted to users due to the presence of locked gates at both ends. The UPR installed the gates within the last decade as a means of reducing traffic for railway safety and fire control in an effort to ensure that operations are uninterrupted. The restricted access aids recruitment of numerous fish and wildlife species. This benefit is diluted to some degree by disturbance and mortality associated with the infrastructure of the railroad and its daily operations.

\section{Anadromous Salmonids}

The Meacham Creek Watershed produces an anadromous salmonid component which contributes to the harvest of both the recreational and commercial fisheries trades located in the Columbia River and Pacific Ocean as well as the traditional and subsistence uses by Native Americans from the Umatilla Basin. To illustrate the significance of Meacham Creek as a salmonid producer, there are more than twice as many salmonids estimated in the lower 15 miles of Meacham Creek than in the lower 81.8 miles of the Umatilla River, despite having less water volume than the Umatilla River. Currently, the Meacham watershed is a primary producer of steelhead trout and is of secondary importance for chinook salmon and bull trout.

Much of the Meacham Creek Watershed is not in compliance with salmonid temperature requirements and corresponding state and federal water quality standards. Thermal guidelines for bull trout state that water temperatures above $15^{\circ} \mathrm{C}\left(59^{\circ} \mathrm{F}\right)$ limit distribution. This benchmark is consistently exceeded in the majority of the Meacham Watershed. Physical habitat survey data is ranked as poor overall and is summarized in Umatilla Basin Natural Production Monitoring and Evaluation Annual Report 1992-1993 (CTUIR 1994).

Meacham Creek's suitability for salmonids is currently classified as marginal, but the restoration potential is good despite limitations imposed by the fixed presence of the UPR. Currently, high stream temperatures, lack of summer flow, limited quantity of pools, lack of overall habitat complexity and shortages of large woody debris are considered as factors limiting salmonid carrying capacity and production in Meacham Creek.

\section{Habitat Enhancement Restoration Activities}

In FY2007, two passage rectification projects were carried out to benefit anadromous salmonid habitat in Meacham Creek. These include: (1) Meacham Creek RM 1.7, removing cabled boulders and planting 50 cottonwoods, 100 alders and 20 willows; and (2) Meacham Creek RM 20.2, partial dam removal, construction of grade control structures with rootwads, and planting 85 alders and 65 willows into the riparian area. 


\section{Camp Creek}

Camp Creek is a tributary of moderate size that enters the mainstem of Meacham Creek at RM 11. Camp Creek contributes roughly 20\% of Meacham Creek’s summer flow and is a known destination for significant numbers of adult steelhead spawning. It is dominated by constraining terraces and predominantly single, Rosgen " $\mathrm{B}$ ” channel morphology (moderate gradient and entrenchment, with very stable banks) (Rosgen 1996). The water quality and habitat conditions of Camp Creek are superior to the adjacent mainstem Meacham Creek. Camp Creek ranked as moderate habitat quality overall for salmonids, primarily due to relative light disturbance and hydrologic stability. Camp Creek receives very little fishing pressure, if any. Hunting opportunities attract the most recreational users, but the remote location keeps use low.

An intensive Aquatic Habitat and Fish Inventory survey was conducted by CTUIR in 1993 on Camp Creek (RM 0-3). Specific results for individual habitat metrics and fish populations can be found in Umatilla Basin Natural Production Monitoring and Evaluation Annual Report 19931994 (CTUIR 1995). In 1994, the number of juvenile salmonids estimated in the lower 3 miles was $6,646,100 \%$ of which were rainbow/steelhead trout.

No bull trout have been documented in Camp Creek, but it is conceivable to foresee the potential of Camp Creek as a rearing area for juvenile bull trout. Historically, Camp Creek would have theoretically supported low to moderate abundance of juvenile bull trout. The potential for a moderate number of juveniles and low numbers of small adults exists. Connectivity problems to existing populations in other areas of the basin appears to be a primary limiting factor of distribution due to undesirable conditions within the migratory corridor.

A 15-ft, natural, bedrock falls located at RM 3.1 effectively eliminates any possibility of upstream movement of fish. CTUIR has documented the lack of fish species present upstream from the falls (CTUIR 1995) and therefore have classified this as a complete, natural fish barrier. We do not recommend modifying passage at RM 3.1 because this particular barrier is natural and is of the highest aesthetic quality. However, in FY2007, CTUIR modified a passage barrier at Camp Creek RM 0.3 that opened up the 2.8 additional river miles of Camp Creek and approaches the headwaters that contain cooler waters, and deep bedrock pools. Riparian plantings included 135 alders and 45 cottonwoods.

\section{Greasewood Creek}

Greasewood Creek is a small tributary that enters Wildhorse Creek (a moderately sized intermittent tributary of the Umatilla River) near RM 9.5, just west of Adams, OR. It is approximately 13 miles long and its headwaters are near the town of Helix, OR. Greasewood Creek lacks high elevation headwaters and is a low gradient system that is surrounded by heavy agricultural land use, predominantly wheat fields on both sides that are commonly plowed to the creek's edge. The substrate is dominated by fines due to very high rates of erosion and runoff. This creek provides marginal habitat for trout with some spring seep refuge areas providing small pockets of thermal refuge that retain flows year round. At present, Greasewood Creek is inhabited primarily by speckled dace and northern pikeminnow, but does support low densities of juvenile salmonids in the lower three miles. Fish use and potential is limited by its geomorphic characteristics and severe degradation from land use impacts. 
Water temperature is a limiting factor to salmonid production in the Wildhorse Basin. The water temperature of Greasewood Creek generally is $2-3^{\circ} \mathrm{C}$ cooler $\left(18^{\circ} \mathrm{C}\left[64.4^{\circ} \mathrm{F}\right]\right.$ vs. $\left.20^{\circ} \mathrm{C}\left[68^{\circ} \mathrm{F}\right]\right)$ during the summer and the water clarity is superior to that of the adjacent Wildhorse Creek. Therefore, lower Greasewood Creek may offer a thermal refuge for salmonids seeking favorable habitat conditions such as cooler water temperatures during the summer months.

Greasewood Creek appears to have a more stable hydrograph than Wildhorse Creek, due to its more abundant springs. This characteristic is theoretically the result of the influential quantity of spring water in the system. Despite the close proximity of Greasewood Creek to Wildhorse Creek, these two systems are uniquely different and offer unique habitat to a variety of aquatic communities.

Greasewood Creek has the potential via restoration to support moderate densities of juvenile salmonids. CTUIR conducted an Aquatic Habitat Inventory and Fish Survey on Greasewood Creek in the summer of 1995. (For data, contact Eric Hoverson, CTUIR, erichoverson@ctuir.com.) Results showed some favorable salmonid habitat in the lower two mile reach. In FY2007, a fish passage barrier was rectified at RM 0.4 on Greasewood Creek.

\section{Birch Creek and West Birch Creek}

Birch Creek is a major tributary that enters the Umatilla River near RM 48.5, five miles west of Pendleton, OR. Birch Creek extends 16 miles before meeting West Birch Creek in the City of Pilot Rock, OR. West Birch Creek is of moderate size and measures 10 miles in length. The Birch Creek Watershed headwaters are characterized by elevations up to 4,000 ft above sea level.

\section{Birch Creek}

The topography of the Birch Creek Watershed is typical of the Blue Mountain foothills, with broad flat ridges bisected by moderately steep, constraining canyons with a variety of aspects across a broad valley floor. The valley floor is comprised of low and high terraces with much incidence of actively eroding banks with an overall lack of instream cover. Thin riparian transects contain sparse tree growth. Water temperatures and habitat conditions throughout Birch Creek are classified as marginal for salmonids. Several passage issues in the lower basin are in the process of being evaluated by the UAFHP and ODFW and are quite problematic for migrating salmonids seeking more desirable conditions in the upstream areas of the basin. The upper reaches consist of moderately-steep, closely orientated hillslopes that cradle the channel and support substantial tree growth, and cooler waters.

Diking and straightening practices have generally concentrated flows into one predominant channel. Therefore, secondary channels account for a small portion of the overall streamlength. Much of the large wood in the Birch Creek Watershed was likely removed to clear lands for agriculture or for timber harvest reasons. The poor health of the banks is primarily attributed to land use practices, such as clearing, overgrazing, and channelization and flashy hydrographs. Due to the relatively high composition of fine substrate and eroding banks, turbidity levels can become relatively high during heavy rainfall events. Summer flows are very low and the surface flow deficiency is magnified due to irrigation withdrawals. Open sky exposure to the wetted channel is at generally at undesirable and excessive levels. 
Mid to lower portions of mainstem Birch are very entrenched and provide poor juvenile rearing habitat for salmonids. Many of these channels have lost connection with their historic floodplain. Their degree of entrenchment is extremely erosive and unstable and produces excessive sediments that fill in pools, embed spawning substrates and accelerate horizontal channel migration.

In addition to poor physical habitat features such as lack of in-stream cover, several water quality issues have been identified as limiting factors of salmonid-rearing production in the Birch Creek Watershed during the summer months. Excessive water temperature, bacteria and sediment loads were identified and listed by the Umatilla Basin TMDL committee. Birch Creek is listed as water quality limited for temperature, habitat modification, and iron concentrations on Oregon's 1998 303(d) list. Extremely low summer flows are very common and magnify the issues with the categorical TMDL and 303d listings.

Despite severe human impacts and limiting factors, the Birch Creek Watershed is the migratory corridor to some of the most important summer steelhead spawning tributaries in the Umatilla River Basin. Its tributaries continue to provide primary spawning areas for adult steelhead and it is a significant producer of steelhead juveniles.

In FY2007 riparian plantings were added to two important areas of Birch Creek where fish passage obstructions were evaluated by Umatilla Basin managers. One project (RM 15.5) was rectified in FY2007; the other (RM 10.3) is still under evaluation.

\section{West Birch Creek}

West Birch Creek land use is primarily rural-residential in the lower reach, crop production and grazing in the middle reach, and timber production in the headwaters. The typical vegetative portrait of the lower two-thirds of West Birch Creek is comprised of crop lands or grasses whereas the upper tributaries present a mosaic of diverse, multi-level grass/shrub/tree growth. West Birch Creek has been heavily impacted by agricultural developments along the majority of its length. There are significant quantities of water withdrawals (up to 100\%) for agricultural uses, diked and straightened channels, areas of severe livestock grazing, and crop fields in close proximity to the stream channel.

The majority of fish that inhabit lower West Birch Creek in the summer are from the family Cyprinidae. CTUIR studies have shown that ratios of non-salmonids (dace, suckers, shiners) to salmonids were approximately 1,000:1 in lower West Birch Creek during the summer.

West Birch Creek has vast, extensive areas of favorable substrate and desirable slope characteristics. These features give the subbasin a favorable spawning potential, but numerous passage issues in the mainstem of Birch Creek hinder the overall potential of this system. If passage and other habitat deficiencies are addressed, the projected potential of steelhead production in the Birch Creek Watershed is quite impressive.

The specific purpose of the passage rectification project on West Birch Creek (RM 3.2) accomplished during FY2007 was to improve fish passage and riparian conditions. The project did not directly address water quality, but contributes to improved watershed health conditions. 


\section{Umatilla River}

The Umatilla River originates on the west slope of the Blue Mountains, east of Pendleton, OR and flows 115 miles in a northwesterly direction to the Columbia River at RM 289. The basin has a drainage area of 2,290 square miles. The mouth of the Umatilla River at Umatilla, OR is at approximately 270 feet elevation above mean sea level. The headwaters are as high as 4,950 feet. The basin's hydrologic unit number is 17070103 (USGS 1989). Many reports describing the Umatilla River are available on the following BPA website URL: http://www.efw.bpa.gov/integratedfwp/reportcenter.aspx).

The Mid-Umatilla River has been highly altered by human development. Stream channel morphology and flows have been significantly altered by irrigation structures and withdrawals, channelization, development, and clearing of the riparian area and adjacent uplands

(CTUIR 2007). Stream temperatures between RM 35 and 49 are positively influenced by cold water releases from McKay Reservoir and provide suitable rearing temperatures for salmonids. These releases elevate flows from 45 cubic feet per second (cfs) to between 250 and 325 cfs (Yoakum, OR flow gage) and decrease water temperatures (CTUIR 2007). The gradient in this reach is relatively constant, and the increased flows provide abundant fast water habitat types (CTUIR 2007). Umatilla River stream temperatures in the 14 miles below the McKay Reservoir are comparable to those found in upper reaches near the headwaters (RM 80-90).

In FY2007, CTUIR installed 2 wells at the Bauer \& Gustafson (B\&G) Resources property (RM 40) for off-channel cattle watering and planted 100 cottonwood saplings in the riparian area.

\section{DESCRIPTION OF ESA LISTED AND SENSITIVE SPECIES IN THE UMATILLA RIVER BASIN PROJECT AREAS}

\section{Bull Trout - Umatilla River Watershed}

Bull trout (Salvelinus confluentus) are a sensitive species in regard to habitat requirements in that they need complex conditions in addition to high quality cold water. Bull trout numbers have declined dramatically from historical levels in the Umatilla Basin due to degraded habitat conditions and the species is classified as "threatened". Adult bull trout population estimates for the entire Umatilla Basin number approximately 500 individuals. The North Fork of the Umatilla River holds approximately $85 \%$ of the basin's bull trout, three fourths of which are located between RM 3-6. The low numbers and concentrated distribution pattern of bull trout in the Meacham Creek Watershed categorizes the population as "increasing threat" and "high risk" of extinction. Not surprisingly a report on the status of Oregon's bull trout (Buchanan and Gregory 1997) classified the small bull trout population in Meacham Creek as "high risk".

It is currently believed that adult bull trout in the Umatilla Basin move downstream in late fall to over-winter in the mainstream Umatilla River where seasonal growing conditions are more suitable. In the springtime, as water temperature begins to increase, adults migrate back into cooler headwater areas. Most bull trout in the Umatilla Basin are residential, showing only limited migratory patterns. The limited movement appears to be an evolutionary adaptation due to the vast detrimental impacts to habitat quality and quantity. 


\section{Bull Trout - Meacham Creek Watershed}

Meacham Creek is classified as critical habitat for bull trout due to its historical importance, knowledge of inhabitance, and potential for connectivity with the core population located in the North Fork Umatilla River. Bull trout numbers in the Meacham Watershed are highest in the headwater tributaries, and considerably lower in the mainstem (Andrus and Middel 2003). An estimated 15 bull trout inhabit the lower 15.3 miles of Meacham Creek during the summer months. It is suspected that bull trout staging in lower Meacham Creek during this time have migrated in from the upper Umatilla River or North Fork Meacham Creek. Population levels of sexually mature bull trout in the entire Meacham drainage is estimated at less than 50 individuals, most of which are located in the North Fork Meacham Creek, which joins the mainstem Meacham Creek at RM 15.5.

Bull trout have never been documented in Camp Creek. Year-round hospitable habitat is found in only a minority of the Meacham watershed, generally near cold water inflows or relatively deep pools with additional desirable qualities such as shade and cover. Therefore a migratory life stage component would appear beneficial to Meacham's bull trout population. The senior author saw only one sub adult bull trout during large wood debris monitoring near Meacham Creek at RM 2.5 on August 28, 2007.

The habitat conditions for bull trout in the mainstem of Meacham Creek are severely limited and currently classified as marginal at best. Meacham Creek currently lacks both the quantity of complex habitat, and water quality essentials associated with systems that have strong populations of bull trout.

Current bull trout management strategy concentrates on protective measures such as fishing restrictions and preventive monitoring of actions that may cause "take". Population estimate trends show moderate increases since 1998. The combination of education, protection and recovery efforts along with habitat enhancement and closed fishing seasons are probable explanations for the positive response.

Protecting the Meacham sub-population is important to preserve the genetic integrity of the species as well as to enhance the migratory corridor from a connectivity standpoint with the primary core population located in the North Fork Umatilla River. The potential for connectivity improves the odds of species preservation over time, especially during catastrophic events and diversifies evolutionary genetic exchange between populations when conditions dictate the necessity for such. Proposed UAFHP restoration activities are intended to improve the status of bull trout in the Meacham Creek watershed by accommodating the specific needs of the species in an effort to increase numbers of this fragile sub-population over time.

The placement of 160 whole trees into Meacham Creek (FY2006) and the rectification of fish passage barriers at RM 1.7 and RM 20.2 of Meacham Creek and RM 0.3 of Camp Creek, FY2007, in addition to riparian plantings, and other planned projects (levee setbacks) will contribute to the ecological restoration of potential bull trout habitat in the Meacham Creek watershed. 


\section{Steelhead Trout - Birch Creek Watershed and Meacham Creek Watershed}

NMFS listed summer Middle Columbia River Steelhead as an Ecologically Significant Unit in 1999. In the Umatilla Basin, the wild steelhead run is supplemented with hatchery stock. Many of the returning hatchery fish reproduce naturally. A portion of wild adults are trapped upon their return from the ocean and spawned artificially at hatchery facilities.

\section{Birch Creek Watershed}

The Birch Creek Watershed was historically, and continues to be, a major producer of summer steelhead trout, but the current population of this ESA-Listed species is at a fraction of historic levels due to detrimental anthropogenic impacts. However, the basin is considered a primary destination for summer steelhead spawning in the Umatilla Basin. Rainbow/steelhead trout have proven to be best suited for conditions in the Birch Creek Watershed and are the most abundant salmonid species. The dominance of this species can be attributed to the beneficial timing of life cycle characteristics and the resilient adaptation to changing conditions in the basin, which has given the species a competitive advantage over other salmonids.

\section{Meacham Creek Watershed}

From 1993-2003, CTUIR established several fish sampling sites throughout the Meacham Creek Watershed. The sites were sampled for fish several times annually, usually during the spring, summer and fall periods. Results showed that densities of captured salmonids were highly variable during different times of year, indicating strong migratory patterns and turnover. Rainbow/steelhead trout are the most abundant salmonid species in the Meacham Creek Watershed throughout the year.

Passage improvements completed in FY 2007 are expected to improve rainbow/steelhead trout distribution and fitness and slightly increase the salmonid carrying capacity in the Meacham Creek Watershed.

\section{Unlisted, Sensitive Species of Significance to Tribal Culture: Middle Columbia Spring Chinook Salmon}

Spring chinook salmon were extirpated from the system in the early 1900s due to seasonal passage issues in the lower Umatilla River caused by irrigating dams and dewatering. A neighboring strain of spring chinook salmon have been successfully reintroduced in the Umatilla River using hatchery techniques. A plethora of management strategies have been successfully exercised in effort to reestablish the species. The abundance of naturally produced juveniles has substantially increased in recent years, and adults now return to the basin annually. Meacham Creek supports all age classes of spring chinook salmon and all age classes show increasing trends of abundance. However, there is little evidence of use by any age class in Birch Creek. 


\section{METHODS, RESULTS, AND DISCUSSION OF STATEMENT OF WORK DELIVERABLES}

Work elements and identifier codes assigned by the BPA Division of Fish and Wildlife are presented in the following section. The work elements and milestone descriptions provide a comprehensive view of FY2007 UAFHP work activities.

\section{A-C165: Complete Environmental Consultation Processes}

CTUIR successfully submitted all applicable and required permitting documents to the appropriate federal, tribal, state, county entities for select implementation projects in a timely manner. Secondary environmental compliance accomplishments during the reporting period included coordination with various compliance personnel to prepare supplemental documentation and reporting for ongoing and planned management actions.

\section{Specifically, CTUIR}

- Prepared two biological assessments (BA) that covered all Meacham Creek and Birch Creek passage barrier rectification projects

- Prepared and submitted Joint Permit Applications to the US Army Corps of Engineers (USACE) and Oregon Department of State Lands (DSL) for the Meacham Creek and Birch Creek passage rectification projects.

- Obtained cultural resource survey/reports for the Birch Creek and Meacham Creek passage projects and obtained cultural resource preservation clearances.

Environmental compliance methods include development of appropriate documentation under various federal, Tribal, state and county laws and regulations governing federally funded project work. Methods involve coordination with various federal and state entities agencies and development and submittal of permit applications, cultural clearances, BAs, National Environmental Policy Act checklists, etc., as necessary. Part of the environmental compliance work element includes planning and developing site-specific proposals tailored to accomplish fisheries goals and meet compliance standards. The details concerning the implementation of treatments and preparations for putting efforts on the ground, including preparations for subcontracting, and specifics in regarding the safeguarding of ESA-Listed species during the implementation process, are outlined in the proposals.

\section{D189: Regional Coordination With Other Agencies in Planning and Implementing Habitat Improvements \\ Coordination with other agencies in planning and implementing habitat improvements in the basin is undertaken to facilitate development of habitat restoration and enhancement projects, participate in subbasin and ESA planning processes and project selection processes, and assist with providing watershed restoration education. CTUIR actively participated in constructive meetings with the ODFW, UBWC, NRCS, Farm Services Agency (FSA), and Umatilla County Soil and Water Conservation District to utilize networking structures and increase cooperative partnerships to strengthen project effectiveness. CTUIR conducted a post-implementation tour of the Meacham Watershed Passage Barrier Rectification projects with cooperating entities including the Interdisciplinary Scientific Review Panel and a tour of the West Birch Creek RM 3.2 passage rectification project with cooperating landowners and consultation entities.}


CTUIR prioritizes this aspect of the program and encourages frequent cooperative efforts with its project partners.

\section{E99: Public Outreach/Education}

Project biologists made a presentation about stream and riparian health at the Pendleton School District Watershed Council Field Days in summer 2007. CTUIR project biologists also interfaced with Native American students at Nixyaawii School's Career Day, teaching the students about work associated with natural resources professions.

\section{F157: Collect/Generate/Validate Field and Lab Data and Analyze Interpret Data: Collect Redd Counts/Suspended Solids/Turbidity, and Benthic Invertebrate Data}

CTUIR independently collected pre-project data on the following: water temperature, aquatic habitat inventory, fish composition, abundance and spawning. CTUIR cooperatively participated in the collection of turbidity, aquatic insect composition and abundance. CTUIR counted steelhead spawning redds and collected carcass data in Meacham Creek in the spring of 2007. Spring chinook redd and carcass data was collected by CTUIR in various areas of the Umatilla River Basin, including Meacham Creek. Cooperating partners at the ODFW conducted steelhead spawning studies in the Birch Creek Watershed. Macroinvertebrate sampling was accomplished via the ongoing professional services of Wooster and DeBano, and data is available in various technical reports available through CTUIR.

\section{Habitat Surveys}

Hoverson (2006) provides details of the 2005 habitat survey that was conducted prior to the large wood implementation project on Meacham Creek. The 2005 data was supplied by the CTUIR in cooperation with the UAFHP and submitted to BPA as a technical report (CTUIR 2007, Appendix 2). Habitat surveys were also conducted in 1993. Specific details for 1993 are published in the CTUIR 1993 Annual Report to BPA, but select details are summarized below. An additional habitat survey was conducted in 2007. General results from these surveys summarized below are being reported due to their vital importance in association with project monitoring.

\section{Habitat Surveys}

In July 1993, the CTUIR Umatilla Basin Natural Production Monitoring and Evaluation (UBNPME) Program collected baseline, pre-treatment and reference habitat information from the mainstem of Meacham Creek, RM 0-15.3, utilizing methods developed by Moore et al., (1993). The overall habitat quality based on ODFW ranking criteria was poor.

The survey results were as follows: (1) 14\% of the quadrats surveyed were dry, (2) wetted braided channels made up $20 \%$ of the stream length and $10 \%$ of stream area, (3) $45 \%$ of habitat units was classified as riffle, (4) $45 \%$ of stream banks were actively eroding, (5) $1 \%$ of bank length was undercut, (7) open sky value of the wetted channel averaged 60\%, (7) 1.6 pieces of large woody debris per $100 \mathrm{~m}(328.1 \mathrm{ft})$, (8) wood complexity score as fish cover averaged 1.2, (9) average stream gradient was 1.3\%, (10) width of the wetted channel averaged 25 times the depth, (11) substrate was dominated by gravels (43\%) and cobbles (40\%) and 200 boulders (>20”) per mile provided important cover and microhabitat for fish (CTUIR 1994). The maximum stream temperature was $74^{\circ} \mathrm{F}\left(23.3^{\circ} \mathrm{C}\right)$. 
The maximum stream temperature found in the 1993 survey was in the lethal range for adult migration, spawning, and incubation. Table 2 shows the temperature tolerances for salmonids (Independent Scientific Group [ISG] 1996). Similar maximum water temperatures have been documented in recent years. The CTUIR UAHFP will strive for creating habitat with optimum water temperatures.

Table 2. Upper and Lower Water Temperature Tolerances for Salmonids

\begin{tabular}{|l|c|c|c|c|}
\hline \multirow{2}{*}{ LIFE STAGE } & \multicolumn{3}{|c|}{ WATER TEMPERATURE $^{\mathbf{0} C}$} \\
\cline { 2 - 5 } & Optimum & $\begin{array}{c}\text { Preferred } \\
\text { Range }\end{array}$ & Stressful & Lethal* $^{*}$ \\
\hline Adult migration \& spawning & 10 & $8-13$ & $>15.6$ & $>21$ \\
\hline Incubation & $<10$ & $8-12$ & $>13.3$ & $>15.6$ \\
\hline Juvenile rearing & 15 & $12-17$ & $>18.3$ & $>25$ \\
\hline *Based on 1 week exposure period, higher tolerances for shorter exposure period. \\
\hline
\end{tabular}

\section{Habitat Surveys}

Habitat surveys were conducted September 7 to October 3, 2005 on Meacham Creek. A total of 56 potential sites on the mainstem of Meacham Creek (Figure 9) were made available to a random generator program for selection of sampling sites. Eleven sites $(12,13,15,17,18,22$, 26, 49, 50, 54, and 56) were selected for habitat monitoring utilizing the Moore et al., (2002) methods and select EDT criteria.

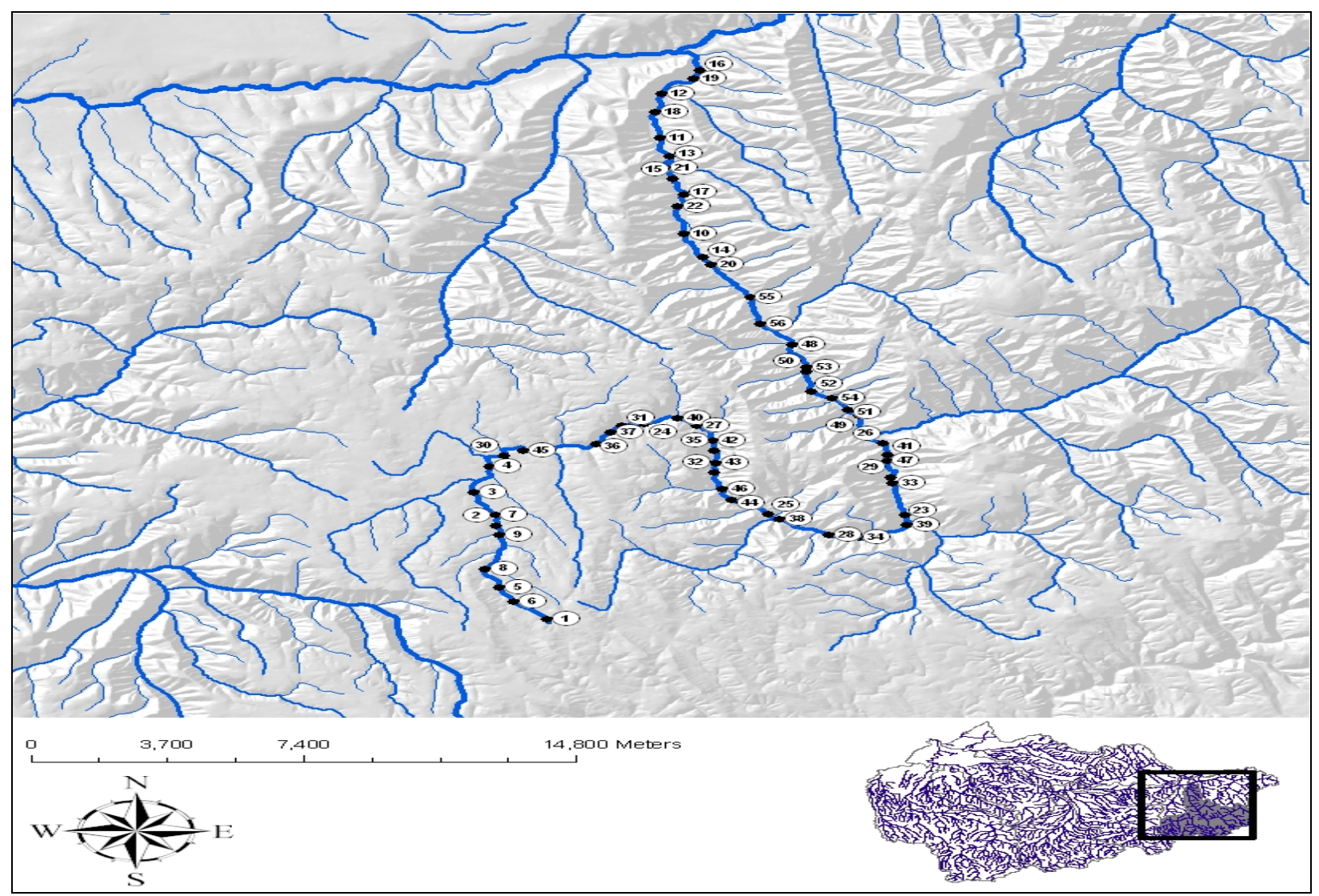

Figure 9. 2005 Pre-Implementation Habitat and Fish Survey Sampling Sites (CTUIR 2005) 
The dimensions of sample-sites varied. Wetted channel widths ranged from 1.8-10.5 m (5.9$34.4 \mathrm{ft}$ ) wide and lengths were 177-313 m (581-1027 ft). There were 135 pieces (12.3 mean per site) of wood tallied that met size and location criteria. A good portion of the woody debris either lacked complexity or was located beyond the wetted channel where it was of little value to fish at the time of survey. Hence, the wood rating as it pertained to fish cover ranked only 2.0. This phenomenon was the direct result of the flashy flow nature of the system as supported by active channel widths measuring 7.4 times as wide as wetted widths.

The average values per sample-site for bed scour, spawning fines, and embeddedness were 4.6, 2.1 and 2.1, respectively. The results indicated very high bed scour with moderate to low amounts of fine substrate in potential spawning areas. Generally, these values met criteria associated with moderately favorable spawning conditions. Undercut values averaged only $10.5 \%$ per quadrat sampled, which indicated a low quantity of overhead cover, essential for providing shading and hiding areas for fish.

There were intermittent concentrations of mature tree growth in the riparian area that received solid habitat rankings, but generally the distance from the wetted channel was too great to provide adequate shading or the width of the riparian strip was rather thin, and flanked by cleared land. Hence, average channel shade values were 37 degrees (angle of shade provided by riparian trees or landforms). Riparian canopy closure values averaged 33\%. The overall habitat quality of Meacham Creek (RM 0-15.3) using ODFW ranking criteria was “poor”.

\section{Habitat Surveys}

Aquatic habitat was inventoried at four habitat enhancement project sites prior to implementation to establish baseline data for comparative analysis and long term effectiveness monitoring. Metrics were calculated per quadrat and expressed as an average value.

\section{Meacham Creek RM 1.7}

A habitat assessment survey was conducted on August 23, 2007. Three quadrats were surveyed over a total stream length of $41.5 \mathrm{~m}(136.2 \mathrm{ft})$. The total wetted river bed area surveyed was $379 \mathrm{~m}^{2}\left(4078 \mathrm{ft}^{2}\right)$. The average high water-bankfull width was $30 \mathrm{~m}(98.4 \mathrm{ft})$ and wetted widths averaged $8 \mathrm{~m}(26.2 \mathrm{ft})$ (3.8:1 ratio). Mean depth of the wetted channel averaged $0.53 \mathrm{~m}$ $(1.73 \mathrm{ft})$. The width to depth ratio was 15.1:1. Habitat composition for the area surveyed was as follows; $60 \%$ pool, 36\% glide, 4\% step. Average substrate composition per quadrat was as follows; $32 \%$ bedrock, 32\% boulder, $16 \%$ gravel, $13 \%$ cobble, $7 \%$ sand. The average values for bed scour, spawning fines, and embeddedness were 3.6, 2.0, and 1.3, respectively. Undercut values averaged only $10 \%$, which indicated a low quantity of overhead cover, essential for providing shading and hiding areas for fish. There were no pieces of wood present at the site that met size and location criteria. The wood rating as it pertained to fish cover ranked only 1.0, the lowest rating possible. Bank composition was comprised of 50\% boulder/cobble, 33\% vegetatively-stable banks, and 17\% non-erodible bedrock material. Mid-channel shade values averaged 44 degrees and riparian canopy closure values were $42 \%$.

\section{Meacham Creek RM 20.2}

A habitat assessment survey was conducted on August 23, 2007. Four quadrats were surveyed over a total stream length of $99 \mathrm{~m}(325 \mathrm{ft})$. The total wetted river bed area surveyed was $408 \mathrm{~m}^{2}$ 
$\left(4390 \mathrm{ft}^{2}\right)$. The average high water-bankfull width was $16.6 \mathrm{~m}(54.5 \mathrm{ft})$ and wetted widths averaged 7.6 (2.2:1 ratio). Mean depth of the wetted channel averaged $0.22 \mathrm{~m}(0.72 \mathrm{ft})$. The width to depth ratio was 34.5:1. Habitat composition for the area surveyed was as follows: 56\% glide, 30\% riffle, 13\% pool, 1\% step. Average substrate composition per quadrat was as follows; $28 \%$ gravel, $25 \%$ cobble, $15 \%$ bedrock, $13 \%$ sand, $11 \%$ silt, $8 \%$ boulder. The average values for bed scour, spawning fines, and embeddedness were 3.3, 3.0, and 3.5, respectively. Undercut values averaged only 6\%, which indicated a low quantity of overhead cover, essential for providing shading and hiding areas for fish. There was one piece of wood present at the site that met size and location criteria. The wood rating as it pertained to fish cover ranked only 1.0, the lowest rating possible. Bank composition was comprised of 50\% boulder/cobble, $38 \%$ nonerodible boulder rip rap material and $12 \%$ vegetatively-stable banks. Mid-channel shade values averaged 41 degrees and riparian canopy closure values were 16\%. The very close proximity of this project site to the rip-rap armored railway had significant impact on the assessed values and classifications.

\section{Camp Creek RM 0.3}

A habitat assessment survey was conducted on August 23, 2007. Eight quadrats were surveyed over a total stream length of $78 \mathrm{~m}(256 \mathrm{ft})$. The total wetted river bed area surveyed

was $140.5 \mathrm{~m}^{2}\left(1510 \mathrm{ft}^{2}\right)$. The average high water-bankfull width was $9.1 \mathrm{~m}(29.8 \mathrm{ft})$ and wetted widths averaged $2.1 \mathrm{~m}$ (6.9 ft) (4.3:1 ratio). Mean depth of the wetted channel averaged $0.14 \mathrm{~m}$ $(0.46 \mathrm{ft})$. The width to depth ratio was $15: 1$. Habitat composition for the area surveyed was as follows: $80 \%$ riffle, $12 \%$ glide, $7 \%$ pool, $1 \%$ step. Average substrate composition per quadrat was as follows: 35\% gravel, 19\% cobble, $19 \%$ sand, $18 \%$ bedrock, $6 \%$ boulder, $3 \%$ silt. The average values for bed scour, spawning fines, and embeddedness were 4.4, 2.3, and 2.6, respectively. Undercut values averaged only 7\%, which indicated a low quantity of overhead cover, essential for providing shading and hiding areas for fish. There were 11 pieces of wood present at the site that met size and location criteria. The wood rating as it pertained to fish cover ranked 2.0. Bank composition was comprised of 50\% boulder/cobble, and 50\% nonerodible bedrock materials. Mid-channel shade values averaged 44 degrees and riparian canopy closure values were $42 \%$.

\section{West Birch Creek RM 3.2}

A habitat assessment survey was conducted on November 26, 2007. Five quadrats were surveyed over a total stream length of $50 \mathrm{~m}(164 \mathrm{ft})$. The total wetted river bed area surveyed was $207 \mathrm{~m}^{2}\left(2227 \mathrm{ft}^{2}\right)$. The average high water-bankfull width was $8.6 \mathrm{~m}(28.2 \mathrm{ft})$ and width of the wetted channel was $4 \mathrm{~m}(13.1 \mathrm{ft})$. Mean depth of the wetted channel averaged $0.32 \mathrm{~m}$ $(1.04 \mathrm{ft})$. The width to depth ratio was 12.5:1. Habitat composition for the area surveyed was as follows; $40 \%$ riffle, $20 \%$ pool, $20 \%$ glide, $20 \%$ step. Average substrate composition per quadrat was as follows; $28 \%$ gravel, $20 \%$ bedrock, $18 \%$ sand, $17 \%$ cobble, $11 \%$ silt, $6 \%$ bedrock. Undercut values averaged only $7 \%$, which indicated a low quantity of overhead cover, essential for providing shading and hiding areas for fish. Fourteen large boulders located in the wetted channel did provide a source of hiding cover for fish. There were no pieces of wood present at the site that met size and location criteria. The wood rating as it pertained to fish cover ranked only 1.0, the lowest rating possible. Bank classification was comprised of 30\% actively eroding banks (from severe downcutting of the channel), 30\% vegetatively-stable banks, $30 \%$ non-erodible materials, $20 \%$, boulder/cobble, and 20\% non-erodible concrete. Mid-channel shade values averaged 35 degrees and riparian canopy closure values were $30 \%$. 


\section{F157: Fish Population Monitoring}

Three intensive aquatic fish inventory electrofishing surveys were conducted by the CTUIR UBNPME Project on Meacham Creek in 1993 (RM 0-15.3) and 2005 (RM 2.2 and 15.5), and 2007 (RM 1.7 and 20.2). Extensive results of the 1993 survey are detailed in the 1994 Annual Report submitted to BPA (CTUIR 1994). Results for 2005 are found in CTUIR (2007, Appendix 2). A general summary of the 1993 and 2005 surveys is being presented in the following paragraphs due to their importance as pre-project baseline data essential for effective monitoring.

\section{Fish Surveys}

Biological Surveys of Meacham Creek RM 0-15.3 were conducted in June 1993 for determining density of juvenile salmonids. The number of juvenile salmonids estimated in the lower 15.3 miles was 71,924 naturally produced rainbow/steelhead juveniles, 1,017 hatchery produced steelhead, and 361 juvenile spring chinook salmon.

Mean density of rainbow/steelhead in the lower 15.3 miles of Meacham Creek was estimated as 20 fish per $100 \mathrm{~m}^{2}$. Comparatively, salmonid densities on the mainstem Umatilla River within the boundary of the Umatilla Indian Reservation (RM 56.1-81.8) were only 3.6 per $100 \mathrm{~m}^{2}$ $\left(1075 \mathrm{ft}^{2}\right)$ whereas densities in the Meacham Creek Watershed average 20-35 /100 $\mathrm{m}^{2}$. There were nearly 2.5 times as many salmonids in the 15.3 miles of Meacham Creek surveyed that in the lower 81.8 miles of the Umatilla River, despite the fact that Meacham Creek has considerably less water volume than the Umatilla River. Estimated densities of rainbow/steelhead in the main tributaries of Meacham Creek were 2-4 times higher than in the mainstem of Meacham Creek. These metrics illustrates the importance of the Meacham Creek Watershed in terms of salmonid production and potential.

\section{Fish Surveys}

Between September 7 and October 3, 2005, CTUIR personnel conducted complete removal electrofishing surveys at 11 Meacham Creek sites (12, 13, 15, 17, 18, 22, 26, 49, 50, 54, 56) between RM 2.2 and 15.5 (Figure 9). Sites averaged $200 \mathrm{~m}(656 \mathrm{ft})$ in length and the cumulative area sampled was $13,452.5 \mathrm{~m}^{2}\left(144,749 \mathrm{ft}^{2}\right)$. Densities for rainbow trout averaged 35 per $100 \mathrm{~m}^{2}$ $\left(1076 \mathrm{ft}^{2}\right)$. Approximately 99\% of captured trout were unmarked, naturally produced rainbow/steelhead trout. Densities for juvenile chinook salmon averaged 1 per $100 \mathrm{~m}^{2}\left(1076 \mathrm{ft}^{2}\right)$. Densities for speckled dace averaged 78 per $100 \mathrm{~m}^{2}\left(1076 \mathrm{ft}^{2}\right)$. Densities for sculpin spp. averaged 49 per $100 \mathrm{~m}^{2}\left(1076 \mathrm{ft}^{2}\right)$.

Multivariate regression analysis concluded that salmonid abundance was strongly related to habitat information, suggestion a strong correlation between fish and habitat conditions. Fish diversity improved the relationship between salmonid abundance and habitat information considerably.

\section{Fish Surveys}

Currently protocol within the CTUIR UAFHP recommends that a pre-implementation fish inventory be conducted to establish baseline data including fish density and species composition. This protocol was established in order to obtain measurable results for our habitat enhancement 
work over time to determine the effectiveness of habitat enhancement actions. Fish surveys were conducted at three habitat enhancement project sites and are discussed below.

In FY2007, no fish surveys were conducted on Meacham Creek, RM 1.7 due to excessive pool depth and at the request of the landowner. Accurate assessments of fish populations would have been difficult due to sampling gear limitations. Therefore, estimates and results may have been inaccurate and misleading to habitat managers.

Meacham Creek RM 20.2

Crews electrofished $35 \mathrm{~m}$ (115 ft) of streamlength in a total area of $140 \mathrm{~m}^{2}\left(1506 \mathrm{ft}^{2}\right)$ on September 5, 2007. A total of 69 rainbow/steelhead trout juveniles were captured, all of which were unmarked, naturally produced fish. The estimated density of rainbow/steelhead trout was 69/100 $\mathrm{m}^{2}$. Thirty-eight (38) speckled dace, 23 sculpin spp., 2 crayfish, and 2 redside shiners were also captured.

Camp Creek RM 0.3

Crews electrofished $54.5 \mathrm{~m}$ (178.8 ft) of streamlength or a total area of $109 \mathrm{~m}^{2}\left(1171 \mathrm{ft}^{2}\right)$ on September 10, 2007. A total of 90 rainbow/steelhead trout juveniles were captured, all of which were unmarked, naturally produced fish. The estimated density of rainbow/steelhead trout was 106/100 $\mathrm{m}^{2}$. Forty-nine (49) sculpin spp. and 4 crayfish were also captured.

West Birch Creek RM 3.2

Crews electrofished $50 \mathrm{~m}(164 \mathrm{ft})$ of streamlength, a total area of $207 \mathrm{~m}^{2}\left(2225 \mathrm{ft}^{2}\right)$

on September 5, 2007. A total of 4 rainbow/steelhead trout juveniles were captured all of which were unmarked, naturally produced fish who appeared to be smolting in preparation for migration to the ocean. The estimated density of rainbow/steelhead trout was $2 / 100 \mathrm{~m}^{2}$. Forty (40) speckled dace, 1 sculpin spp., 1 redside shiner, and 1 sucker spp. were also captured.

\section{G162: Analyze/Interpret Data: Redd Counts, Suspended Solids, \& Invertebrate Data} CTUIR participated in the analysis and interpretation of suspended solids, steelhead redd data on Birch Creek and salmon/steelhead redd data on Meacham Creek, and benthic invertebrate data on Meacham Creek and the Umatilla River. Results of the findings are available in various outsourced reports and can be requested through CTUIR's UAFHP.

\section{H172: Conduct Pre-Acquisition Activities: Acquire Conservation Easements for Improvements on Birch Creek}

CTUIR has secured several long-term conservation easements in the Birch Creek Watershed. CTUIR staff initiated on site care, maintenance, and improvements to the properties and discussed details of the easements and future plans with the cooperating landowners.

\section{I175: Produce Engineering Design and/or Specifications: Birch/Meacham Creek projects} Design drawings and specifications for FY2007 projects, mainly in the Birch Creek and Meacham Creek watersheds, were successfully completed and were an important step towards receiving permission to proceed from regulatory agencies.

\section{J34: Develop Alternative Water Source: Dig Well as Alternative to Dam Diversion on Birch Creek}

Environmental compliance, engineering designs and implementation contracts were granted but any work, other than riparian plantings at RM 2.3 and 10.3 has been suspended indefinitely due CTUIR Umatilla Anadromous Fisheries Habitat Project NPPC Project\# 1987-100-01

FY2007 Annual Report 
to disagreements between adjacent landowners. It is standard operational procedure for the CTUIR UAFHP to have approval from all parties involved prior to proceeding. CTUIR worked closely with Oregon Water Resources Department (OWRD) and the landowners to plan these projects.

\section{K34: Develop Alternative Water Source: Install Well for Alternative Livestock Water Source on B\&G Easement}

This project is located at RM 40 on the Umatilla River at the B\&G Resources Property Easement. Planning with landowners, the NRCS and FSA included site visits and several meetings to confirm design specifications and project details. Two wells were drilled to provide off-channel watering sources for livestock on January 18, 2008 to the following specifications shown in Table 3.

Table 3. B\&G Resources Off-Channel Livestock Watering Wells Specifications

\begin{tabular}{|c|c|c|c|}
\hline Well Number & Location & Depth (ft) & Gallons Per Minute \\
\hline Well \#1 & North side of river & 55 & 80 \\
\hline Well \#2 & South side of river & 105 & 40 \\
\hline
\end{tabular}

Well \#2 was drilled twice as deep as well \#1 to increase the odds of water availability throughout the dry season. Solar-powered watering troughs are scheduled for completion in FY2009.

\section{L149: Install Pipeline: Install Buried PVC Irrigation Mainlines}

This work element was not performed in FY2007. This work concerns installing PCV pipelines at two wells and was contingent on CTUIR receiving permission to rectify passage at Broun Dam, and landowner agreement to a point of diversion (POD) change. This work was eventually denied due to disagreements between landowners in regard to details concerning changing the proposed POD.

M40: Install Fence: Install Fence on Broun Easement, Birch Creek Environmental compliance documents were completed for installation of a livestock exclusion fence on this property through NRCS. The blueprint for the design is on file but installation is suspended due to landowner disagreements regarding POD changes and dam modifications. The project is anticipated to be completed in FY2009.

\section{N85: Remove/Breach Dam: Negotiate Removal of Broun Diversion Dam Passage Impediment}

This project was proceeding until landowner disagreements halted the process, suspending the project indefinitely.

\section{O85: Remove/Breach Dam: Negotiate the Removal of Peterson Diversion Dam Passage Impediment}

This project was planned and contracted for work to be performed in FY2008. CTUIR maintained coordination and oversight from OWRD and the partial dam removal was discussed on site with the cooperating landowner on several occasions. CTUIR was successful in securing agreements with two of three landowners, but needed 100\% agreement to proceed. However, CTUIR did secure agreements to participate in riparian enhancement activities on the properties in the hopes that an agreement to modify passage at Peterson Dam will be realized in the future. 
P184: Install Fish Passage Structure: Install Fish Ladder at Hoeft Dam, West Birch Creek Planning, completing environmental compliance documents, and initial site preparations for this project occurred in FY2007. Much progress was made in regard to operational details by way of several technical meetings and discussions with the engineer, landowner and cooperating partners. The contractor completed fabrication of all 13 sections of the concrete fishway, but installation was postponed due to inclement weather. Complete installation of the fishway is scheduled for FY2008.

\section{Q184: Install Fish Passage Structure: Install Roughened Channel Cunningham Sheep} Company Culvert, West Birch Creek

Planning activities for this project were conducted and the project was successfully completed on November 27, 2007. The CTUIR used a "roughened channel strategy" to reestablish proper stream gradient and rectify passage. This technique functions like a rock weir, but with natural aesthetic value and abundant microhabitat for rainbow/steelhead trout. CTUIR sloped an eroding bank which was then seeded with native grass. Hundreds of trees were planted at this project site.

\section{R29: Increase Instream Habitat Complexity: Install Rock Cross Veins in Meacham Creek Cross veins were installed in FY2007 in association with two dam removals projects Three cross veins were installed; two at Meacham Creek at RM 20.2 and one at Camp Creek, RM 0.3. The function of cross veins is to maintain proper stream slope following channel alteration.}

\section{S29: Increase Instream Habitat Complexity: Plan Removal of Levees, Meacham Creek Floodplain}

In FY2007, CTUIR conducted surveying of the levees and development planning activities have continued and matured in scope. This work is scheduled to be completed in FY2008 and will be reported in the FY2008 Annual Report.

T47, U 47, W 53: Planting and Maintenance of Vegetation, Control Noxious Weeds During the FY2007 project period, several tree planting efforts were completed in riparian areas including Meacham Creek (RM 1.7 and 20.2), Camp Creek (RM 0.3), West Birch Creek (RM 3.2), Birch Creek (RM 10.3), and Umatilla River (RM 40). In addition, 100 willow saplings were donated to the ODFW for the Weinke passage improvement project on Birch Creek (RM 15.5). Eighty pounds of native grass seed were applied to the B\&G Resources Project at RM 40 of the Umatilla River near well site \#2 and 50 pounds were seeded at West Birch Creek (RM 3.2). Soil preparation and noxious weed control activities were emphasized at the B\&G property in preparation for seeding 107 acres of native grasses scheduled for FY2008.

Planting tasks include site planning and development of planting strategies, collection and preparation of materials (pruning and conditioning of live whip material), pre-order coordination with the CTUIR native plant nursery (Figure 10), and installation. Planting techniques are customized for conditions within each project area. Planting location, species, age, form (cuttings, saplings, bare-roots, potted, plugs), and soil/substrate conditions were considered and addressed during the implementation planning phase.

Noxious and/or undesirable weeds are present on several project areas held in easement agreements with CTUIR. CTUIR subcontracts professional, licensed applicators to spray/control 
noxious weeds on several project sites. CTUIR complies with BPA standards and supplies a report to BPA detailing the types and quantities of herbicides applied to specified locations.

The frequency of watering, weeding and maintenance methods for each easement or project site varies. Strategies to address weeds are included in agreements that are either completed by the landowner, CTUIR, subcontractor, and/or through the County Weed Control Board (CWCB). CTUIR staff provides assistance to landowners by coordinating and managing herbicide application vendors, providing funding, and developing treatment strategies. Manual, biological, and chemical treatment options are utilized by CTUIR and may be employed when consistent with existing standards. Primary weed species prioritized for treatment in the Umatilla River Basin include leafy spurge, spotted knapweed, Canada thistle, yellow star thistle, and other non native species.

The CTUIR UAFHP relies heavily on the nursery to provide plants for use on restoration projects. Features of the ever expanding nursery include a greenhouse, refrigerated cooler, irrigated stool beds, and containerized plant stock and its capabilities are growing steadily (Figure 10). The availability and quantity of plants is increasing on a daily basis due to demand, increased funding, and professional staffing.

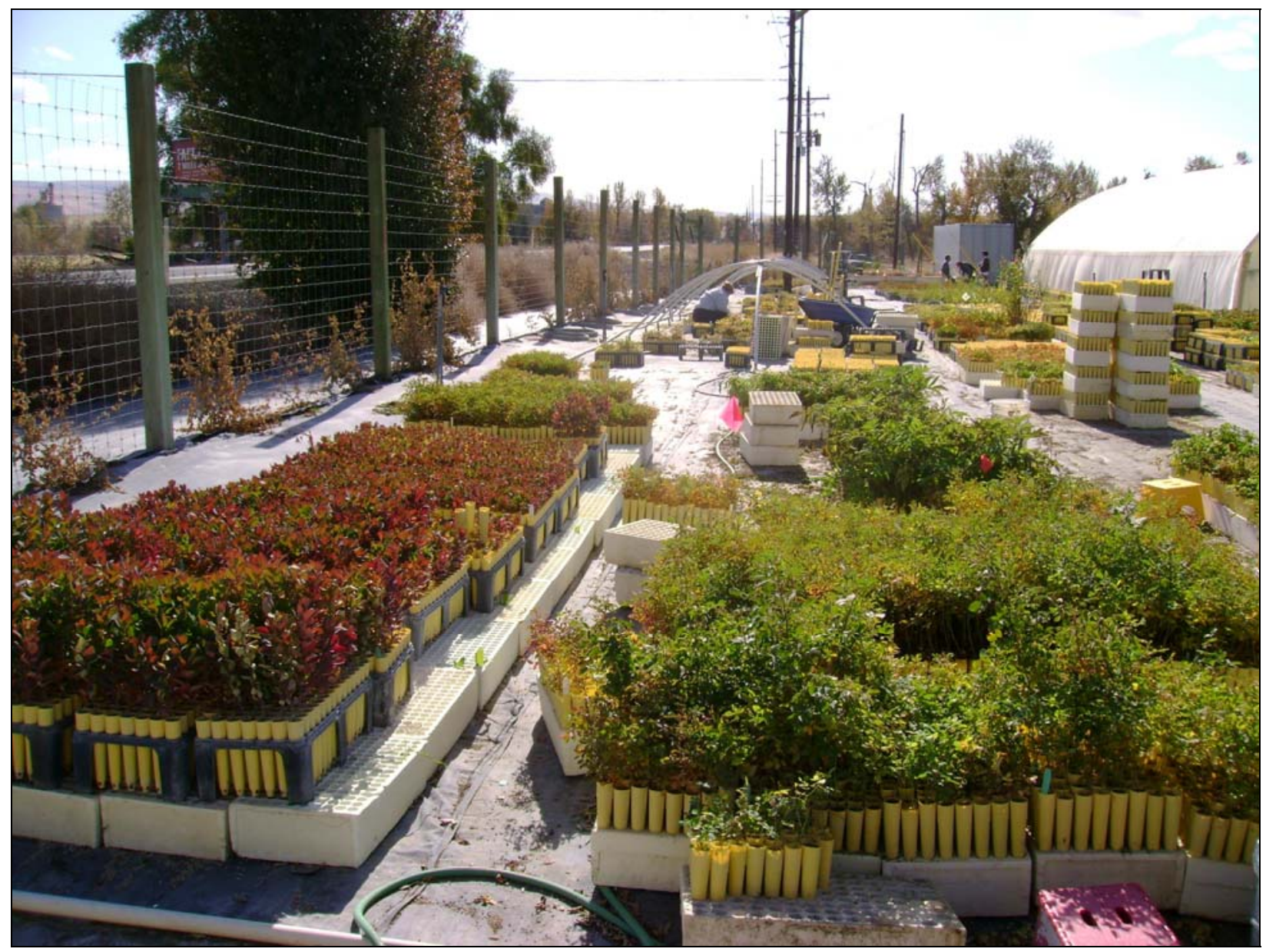

Figure 10. CTUIR Native Plant Nursery Stool Beds and Containerized Plant Stock 
CTUIR UAFHP also contributes native plants and fencing materials to its partners to assist them in their restoration efforts. An example is the donation of 100 willows to ODFW for a restoration project at Weinke property (Figures 11 and 12) on Birch Creek (RM 15.5).

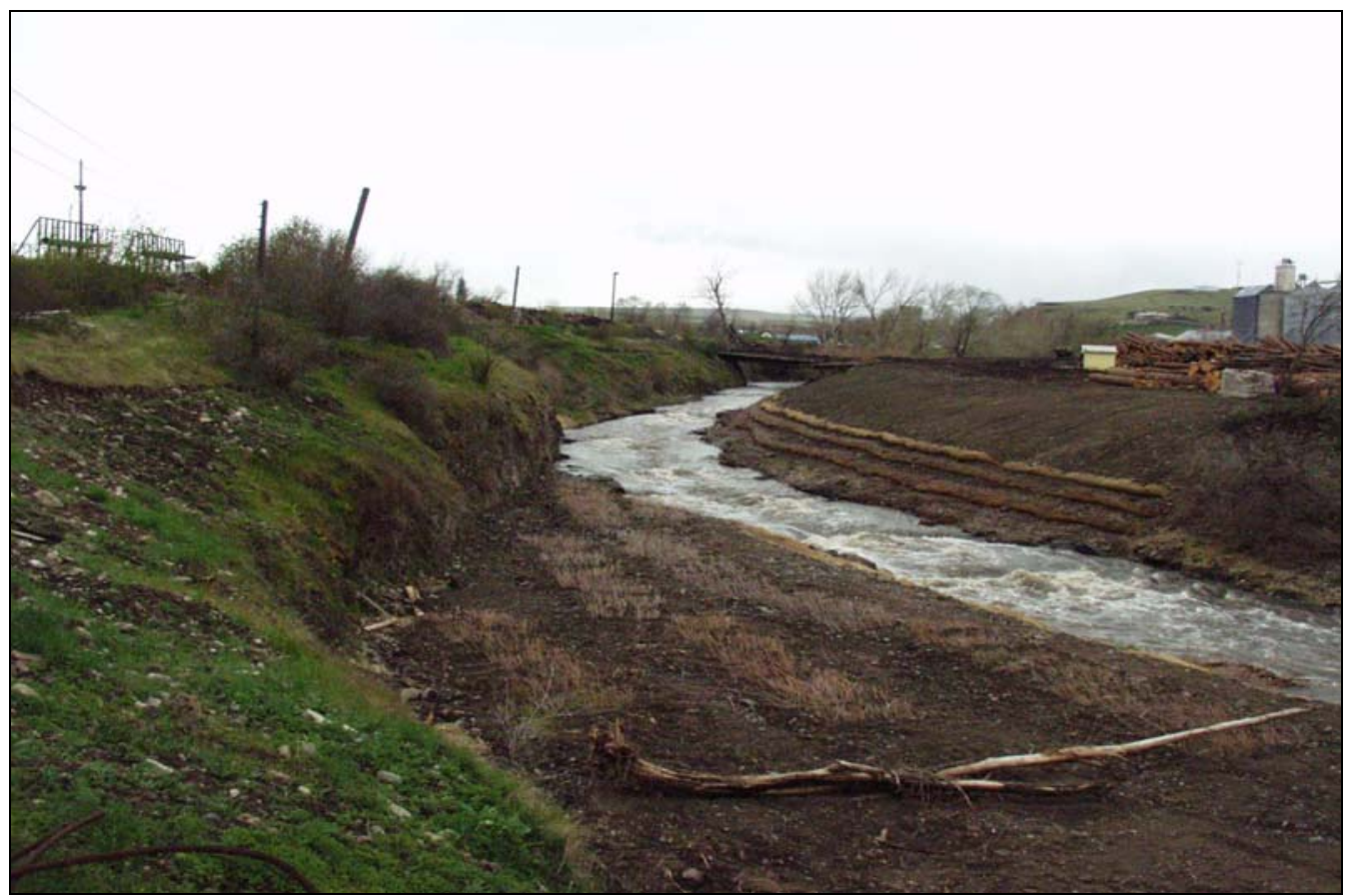

Figure 11. Weinke Dam Passage Rectification Project Partnership with ODFW Showing Willow Plantings, Birch Creek, RM 15.5 - December 2007

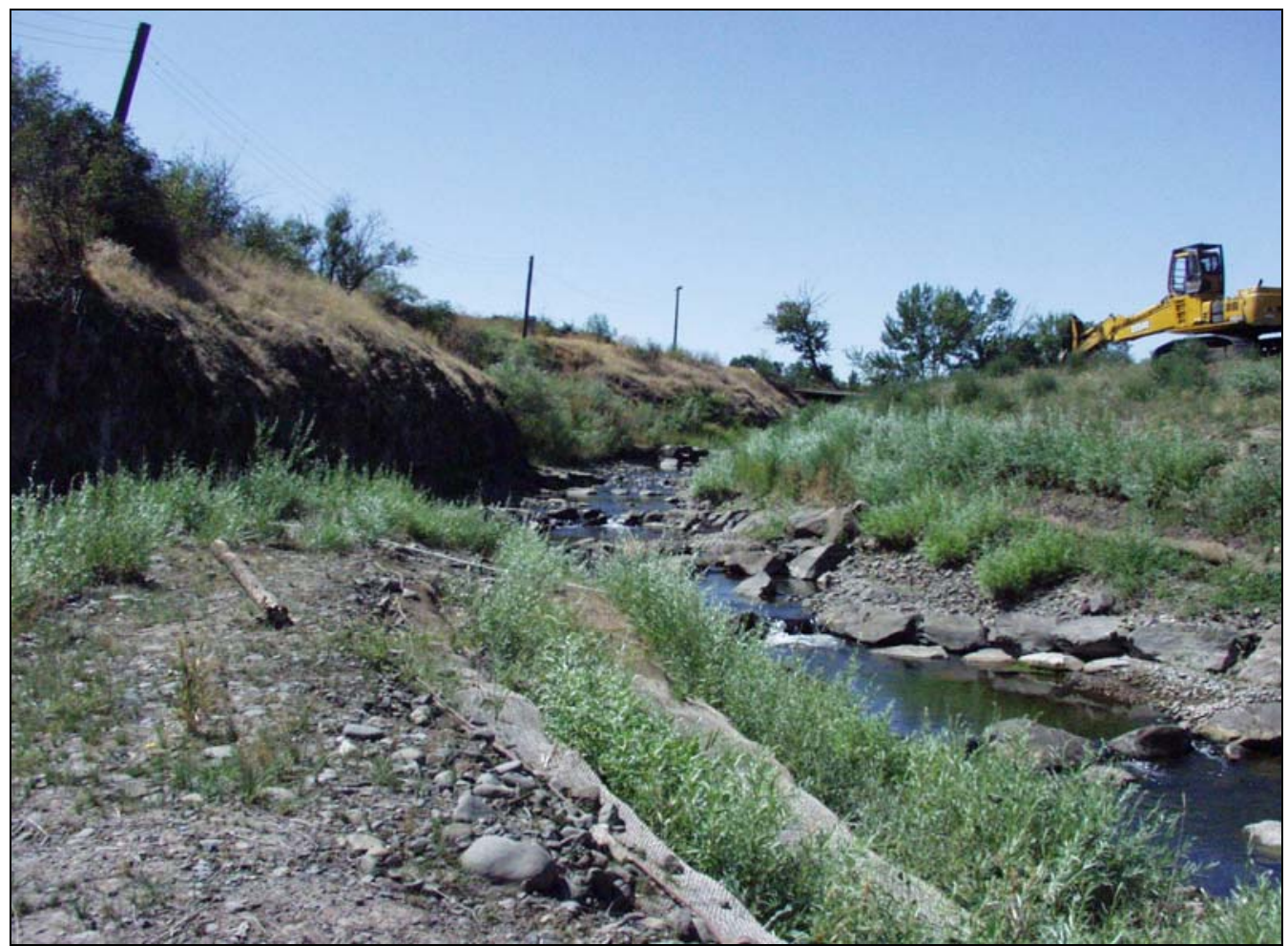

Figure 12. Weinke Dam Passage Rectification Project Partnership with ODFW Showing Progress of Willow Plantings, Birch Creek, RM 15.5 - July 2008 
V22: Maintain Vegetation Planted Previously on Conservation Easements Properties Project activities conducted in FY2007 included the monitoring and maintenance of 27 conservation easements on 23 individual landowner properties. CTUIR personnel routinely maintain and replant vegetation, water and weed plantings, and maintain structural integrity of riparian enclosure and livestock fencing. Table 4 provides a list of the waterways on which the easements are located, duration and details of agreements, associated actions and the CTUIR recommended renewal status projections.

Table 4. Conservation Easements Maintained by the CTUIR: Locations, Duration, Agreement Details and Recommended Renewal Status Projections

\begin{tabular}{|c|c|c|c|c|c|c|}
\hline \# & Waterway & $\mathbf{R M}$ & Start Date & End Date & Actions Performed & $\begin{array}{l}\text { Renewal } \\
\text { Status }\end{array}$ \\
\hline 1 & Wildhorse & 9.5 & $5 / 1 / 2004$ & $5 / 1 / 2024$ & $\begin{array}{l}\text { fence, weed, plant, watering, } \\
\text { weeding, gradient }\end{array}$ & No \\
\hline 2 & Wildhorse & 12.0 & 10/12/1995 & 10/12/2010 & $\begin{array}{l}\text { fence, weed, plant, watering, } \\
\text { weeding, gradient }\end{array}$ & No \\
\hline 3 & Wildhorse & 12.5 & $5 / 1 / 2004$ & $5 / 1 / 2024$ & $\begin{array}{l}\text { fence, weed, plant, watering, } \\
\text { weeding, gradient }\end{array}$ & No \\
\hline 5 & Umatilla & 42.0 & $1 / 1 / 2001$ & $1 / 1 / 2016$ & fence, weed & No \\
\hline 6 & Umatilla & 43.0 & $1 / 25 / 2003$ & $1 / 25 / 2023$ & fence, weed, well & No \\
\hline 7 & Cottonwood & 1.0 & $10 / 1 / 2001$ & $10 / 1 / 2026$ & culvert replacement & No \\
\hline 8 & Mission & 2.5 & $1 / 1 / 2001$ & $1 / 1 / 2011$ & barrier remedy, fence, native grass & Yes \\
\hline 9 & Umatilla & 68.5 & $10 / 1 / 1999$ & $10 / 1 / 2014$ & None & Yes \\
\hline 10 & Buckaroo & 1.0 & $10 / 1 / 1999$ & $10 / 1 / 2014$ & None & Yes \\
\hline 11 & West Birch & 3.2 & 11/4/1999 & $11 / 4 / 2014$ & $\begin{array}{c}\text { barrier remedy, plantings, water, } \\
\text { weed }\end{array}$ & Yes \\
\hline 12 & McKay & 16.5 & 6/1/1999 & $6 / 1 / 2014$ & $\begin{array}{l}\text { education, bio monitoring, plant, } \\
\text { weed }\end{array}$ & No \\
\hline 13 & Umatilla & 40.0 & 9/30/2004 & $9 / 30 / 2024$ & plant, weed, water, wells & No \\
\hline 14 & East Birch & 10.5 & 9/1/1997 & $9 / 1 / 2017$ & fence construction, maintenance & No \\
\hline 15 & Umatilla & 82.5 & $7 / 1 / 2000$ & $7 / 1 / 2015$ & instream bank protection & Yes \\
\hline 16 & McKay & 17.0 & 12/2/1995 & $12 / 2 / 2011$ & $\begin{array}{l}\text { education, bio monitoring, plant, } \\
\text { weed }\end{array}$ & No \\
\hline 17 & West Birch & 2.7 & $2 / 1 / 2005$ & $2 / 15 / 2025$ & Passage remedy, plant, water, weed & Yes \\
\hline 18 & Buckaroo & 1.0 & 10/1/1999 & $10 / 1 / 2014$ & None & Yes \\
\hline 19 & Wildhorse & 7.5 & $11 / 4 / 1994$ & $11 / 4 / 2009$ & fence, gradient, weed & No \\
\hline 20 & Buckaroo & 1.5 & $5 / 7 / 2002$ & $5 / 72022$ & fence, bio monitoring & Yes \\
\hline 21 & Spring Hollow & 2.5 & 9/1/1996 & 9/1/2011 & plant, fence, bio monitor & No \\
\hline 22 & Birch & 2.7 & $10 / 1 / 1999$ & $10 / 1 / 2014$ & plant, weed, water & Yes \\
\hline 23 & Wildhorse & 8.5 & $10 / 1 / 2002$ & $10 / 1 / 2020$ & fence, gradient, weed & No \\
\hline 24 & Umatilla & 87.5 & $10 / 1 / 2002$ & $10 / 1 / 2020$ & $\begin{array}{c}\text { instream bank protection, channel } \\
\text { shaping }\end{array}$ & Yes \\
\hline 25 & Umatilla & 61.5 & $10 / 1 / 2002$ & INDEF & instream bank protection, planting & Yes \\
\hline 26 & Greasewood & 0.5 & 10/12/1995 & $10 / 12 / 2010$ & $\begin{array}{l}\text { barrier remedy, fence, weed, plant, } \\
\text { bio monitor }\end{array}$ & Yes \\
\hline 27 & Meacham & 0.5 & 10/1/1999 & $10 / 1 / 2014$ & fence, weed & Yes \\
\hline
\end{tabular}


X186: Operate and Maintain Habitat/Passage/Structure: Repair Damaged Fencing and Gates

Project maintenance includes conducting custodial responsibilities on individual projects to ensure that developments are functioning repair and habitat recovery is progressing towards meeting projects goals and objectives. Activities include, but are not limited to, maintaining communications and good standing with landowners, installing and repairing fences (Figure 13), maintaining or installing water gaps, or other developments that will protect or improve riparian and riverine conditions. Project sites are monitored regularly by CTUIR staff to ensure that adaptive management strategies can occur in a timely manner. For example, project impacts from trespass livestock were minimized by working with the owners to relocate problem livestock from project areas. Increased staffing and focus will target further improvements in project maintenance. Damaged fencing and gates were repaired in a timely manner at several CTUIR easements in FY2007.

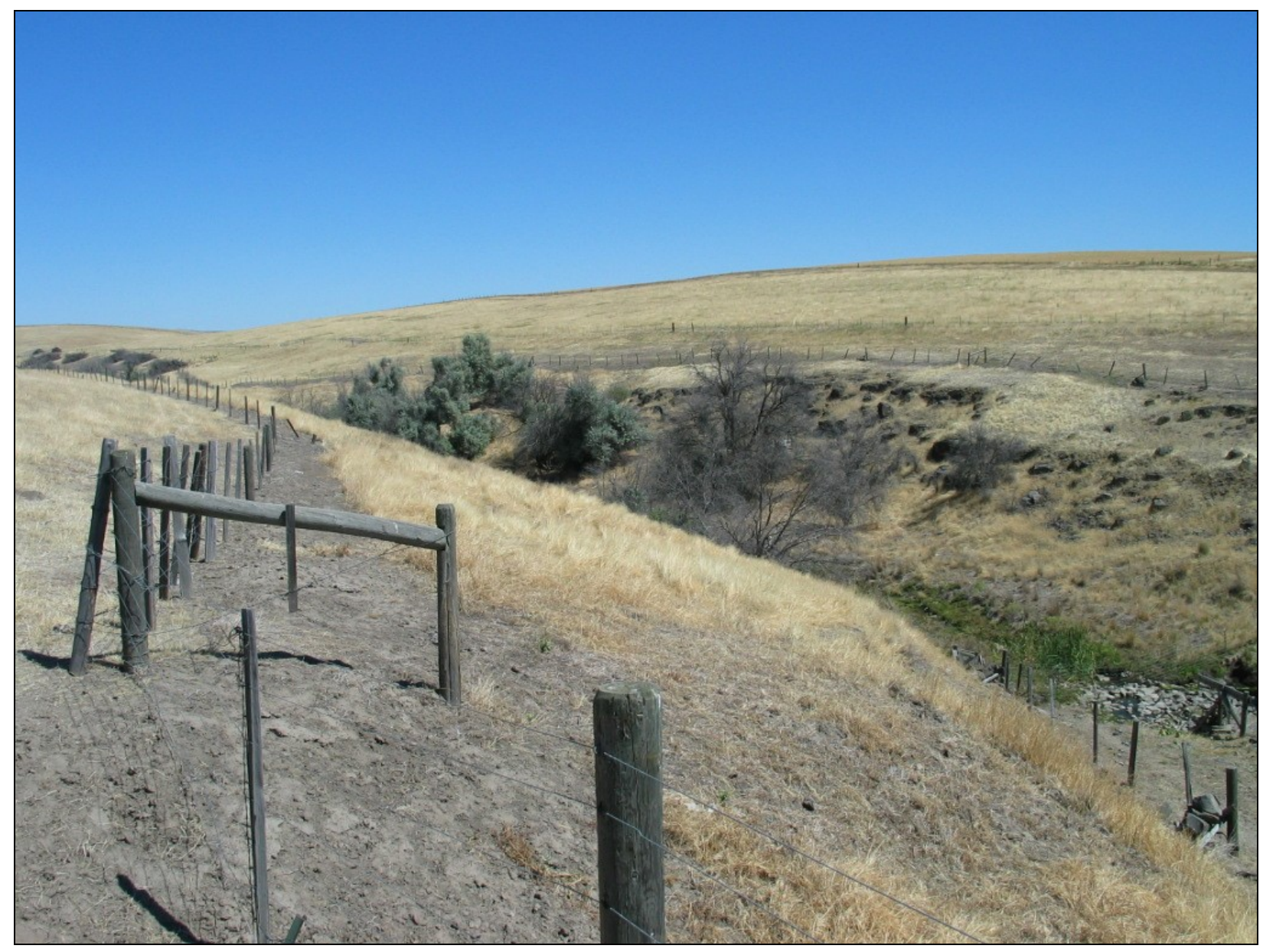

Figure 13. Example of Livestock Exclusion Fencing at Greasewood Creek Easement. Cattle Trespass Had Caused Significant Damage to the Riparian Area Prior to CTUIR Reinforcing the Fence in FY2007

\section{Y186: Operate and Maintain Habitat/Passage/Structure: Conduct Operation and} Maintenance Activities on Instream Improvement Structures - Monitoring and Evaluation Monitoring of individual projects is conducted either independently by the CTUIR or jointly with project partners such as ODFW. CTUIR monitoring professionals reported the removal of a 
small logjam at the Cunningham barrier rectification project that was impeding passage and deflecting flows towards the east bank and causing notable erosion. CTUIR conducts ongoing maintenance to keep the passage projects clear of debris that accumulates over time, as specified in the conditional language of state and Federal permits. For example, CTUIR staff removed an embedded log on Meacham Creek at RM 1.7 that was forming a step following completion of the passage rectification project.

Monitoring and evaluation efforts include annual photo points, installation of water quality monitoring devices, channel cross sections, longitudinal surveys, fish population and habitat surveys, census evaluation surveys on revegetation efforts, and groundwater monitoring. Posttreatment surveys are routinely conducted to monitor and quantify changes to physical, biological, and ecological components of the system, and to identify trigger-mechanisms responsible for instigating change.

In conjunction with maintaining activities on instream improvement structures, public tours, workshops, and presentations of individual projects were conducted during the reporting period. These activities provide for the discussion of various approaches, restoration techniques, successes, failures, and ultimately adaptive management. Monitoring activities conducted by the UAFHP in FY2007 will contribute towards providing improvements in habitat conditions and continued progress towards the goal of eradicating limiting factors detrimental to salmonid populations.

\section{Z122: Provide Technical Review of Plans and Proposals}

CTUIR commented on applications for OWEB grants in coordination with the UBWC, on CTUIR's Department of Water Quality plans, Section 404 removal and fill permits, on Department of Transportation plans, and DEQ pollution control plans during FY2007. The review process was achieved within the allotted time frames.

\section{AA174: Produce Plan: Preparation of Six Project Management Plans}

CTUIR drafted the following project plans for evaluation:

- Levee setback and removal in Meacham Creek floodplain

- Channel and instream improvement, Meacham Creek

- Assessment passage barrier amelioration at RM 11, Birch Creek

- Assessment passage barrier amelioration at RM 12, Birch Creek

- Assessment passage barrier amelioration at RM 1, W. Birch Creek

- Riparian and floodplain restoration and enhancement, Whitney Easement, Birch Creek

\section{AB132: Produce Annual Report}

Annual reports provide updates on project progress on an annual basis and follow standard BPA formatting. The final draft FY2005 and FY2006 annual report was completed by March 31, 2007. By submission of this FY2007 Annual Report, CTUIR has fulfilled its contractual obligations to BPA by reporting the FY2007 project details.

\section{AC119: Manage and Administer Projects}

This work element includes a suite of management actions required to administer the project, including preparation of annual operations and maintenance budgets, managing and preparing statements of work (SOW) and budgets, and property inventory to the assigned BPA Contracting Officer Technical Representative (COTR). The project leader reports milestone and metrics to 
BPA using the BPA Pisces Program, supervises, trains, and directs staff activities, conducts vehicle and equipment maintenance and management, performs payroll, purchasing, subcontracting for services, and administers habitat enhancement activities.

\section{AD185: Produce Pisces Status Reports and Periodic Status Reports for BPA}

Quarterly Pisces reports were prepared on schedule and reviewed and accepted by the BPA project COTR. These reports provide a regular update on project progress on status of work elements and associated milestones.

\section{SELECTED FY2007 FISH HABITAT ENHANCEMENT AND RESTORATION ACTIVITIES}

The following section provides selected project information for several of the eight primary projects separated into five general action categories implemented by CTUIR's UAFHP in FY2007. Table 5 provides project metrics for projects 2, 3, and 5 and additional information on projects 1 and 4 (see Figure 2).

Table 5. Actions and Metrics Associated with the FY2007 UAFHP Restoration Project Activities

\begin{tabular}{|c|c|}
\hline Action & Project Metrics \\
\hline $\begin{array}{l}\text { 1. } \text { Project Monitoring } \\
\text { - Macroinvertebrate: } 13 \text { sites, } \\
\text { Meacham Cr, Umatilla R } \\
\text { - Temperature: } 40 \text { sites, Meacham Cr } \\
\text { - Turbidity: Meacham Cr, RM } 1.8\end{array}$ & $\begin{array}{l}\text { - Before and After Photos of } 7 \text { FY2007 Projects } \\
\text { - Aquatic Habitat Inventory at } 4 \text { Sites } \\
\text { - Fish Inventory at } 3 \text { Sites } \\
\text { - Photo Points of } 27 \text { Easements } \\
\text { - } 36 \text { Photo Points of FY2006 Project }\end{array}$ \\
\hline $\begin{array}{l}\text { 2. Rectification of Fish } \\
\text { Passage Barriers }\end{array}$ & $\begin{array}{l}\text { - Partial Dam Removal, Meacham Cr, RM } 20.2 \\
\text { - Partial Dam Removal, Camp Cr, RM } 0.3 \\
\text { - Partial Dam Removal, Greasewood Cr, RM } 0.4 \\
\text { - Cabled Boulders Removed, Meacham Cr, RM } 1.7 \\
\text { - } \text { Roughened Channel, West Birch Cr, RM } 3.2\end{array}$ \\
\hline 3. Riparian Plantings & $\begin{array}{l}\text { - } 120 \text { Alder, } 85 \text { Willow, } 50 \text { Cottonwood, Meacham Cr, RM } 1.7 \\
\text { - } 100 \text { Willow, Birch Cr, RM } 15.5 \\
\text { - } 100 \text { Cottonwood, } 100 \text { Alder, Birch Cr, RM } 10.3 \\
\text { - } 275 \text { Alder, } 75 \text { Willow, } 25 \text { Cottonwood and 50\#s of Native } \\
\text { - Grass Seed, West Birch Cr, RM 3.2 } \\
\text { - } 200 \text { Alder, } 45 \text { Cottonwood, Camp Cr, RM } 0.3 \\
\text { - } 100 \text { Cottonwood, 80\# Native Grass, Umatilla R, RM } 40\end{array}$ \\
\hline 4. Cattle Exclusion Fencing & $\begin{array}{l}\text { - } 2 \text { Miles Riparian Fence, Greasewood Cr, RM } 0.5 \\
\text { - } 8 \text { Water Gaps, Greasewood Cr, RM } 0.5\end{array}$ \\
\hline $\begin{array}{l}\text { 5. Wells For Off-Channel } \\
\text { Cattle Watering }\end{array}$ & - Constructed 2 Wells, Umatilla R, RM 40 \\
\hline
\end{tabular}




\section{Monitoring}

In addition to project implementation, various forms of ongoing monitoring activities are exercised by the CTUIR UAFHP. Monitoring plans are intended to provide a comprehensive measurement of effectiveness of restoration actions and are intended to measure project changes over a range of physical and biological parameters through time. Parameters include suspended sediment and turbidity, stream temperature at specific points throughout the project reach and monumented cross-sections, longitudinal profiles, stream habitat surveys, macroinvertebrate sampling, and fish sampling. A portion of the temperature and suspended sediment characteristics have been monitored since the mid-1990s and will continue for the purpose of long-term trend analysis. Additional forms of monitoring have also been used, such as the experimental design regimen of Before-After, Control-Influence or BACI (Smith 2002). Well planned monitoring strategies offer a means to quantify measurable results of habitat actions which promotes adaptive management to achieve optimal results. Project site visits are also conducted to enable identification of deficiencies or potential impacts to restoration activities. Addressing impacts in a timely manner increase the probability of project success.

\section{Photo Point Monitoring of Meacham Creek Large Wood Placement Project}

Permanent photo points have been taken on an annual basis to show project changes and are now schedule on a bi-annual basis. Photo points are established and repeated at various intervals at project implementation sites such as the Meacham Creek LWD project (Figure 14). In FY2007, standardized photos were taken to provide a visual record of changes in channel morphology and riparian recovery at the LWD Implementation sites in Meacham Creek and correlated to flow data derived from a USGS internet web site. Photos are cataloged and stored on computer hard drives and back up disks maintained by the CTUIR Fisheries Habitat Enhancement Project. This information provides a very valuable visual source of restoration progress and is also used for public education.

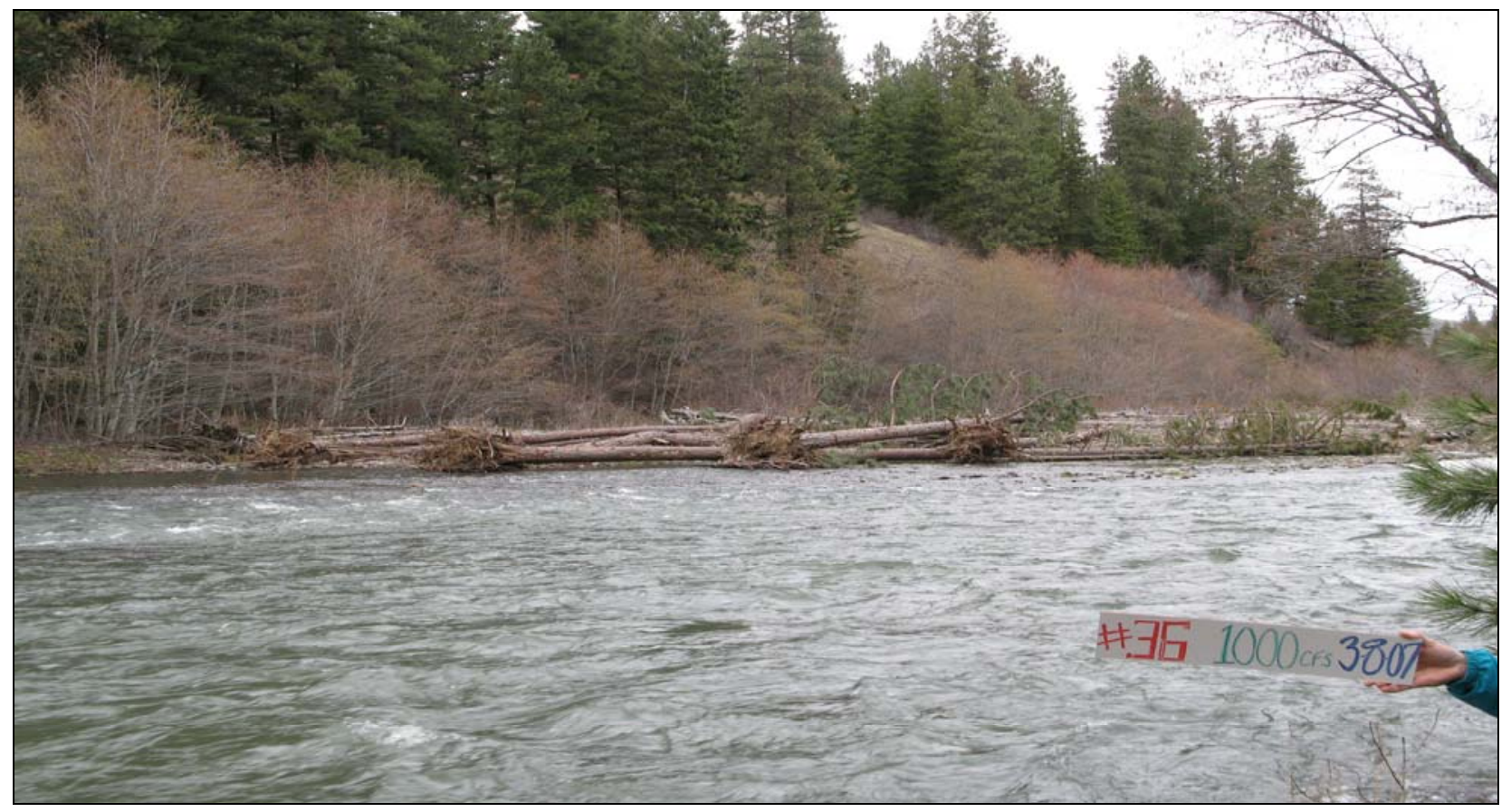

Figure 14. Photo Point Monitoring Methodology of Meacham Creek LWD Configurations

CTUIR Umatilla Anadromous Fisheries Habitat Project FY2007 Annual Report 


\section{Fish Passage Barrier Rectification: Meacham Creek, Camp Creek, Greasewood Creek, West Birch Creek}

An analysis of habitat conditions in the Umatilla Basin was conducted by CTUIR and ODFW. The Meacham and Birch Creek watersheds were identified by CTUIR and ODFW in the FiveYear Action Plan for the Development and Maintenance of Habitat Improvement Projects in the Umatilla Subbasin: 2006-2010 (CTUIR and ODFW 2006) as priority areas for fish habitat restoration activities. In addition to the historical relevance of these watersheds, fisheries data collected over the last two decades illustrated the importance of the basin to anadromous and resident salmonids. These watersheds are a primary focal point of the CTUIR effort to improve habitat conditions in the Umatilla Basin because of the current habitat status, historical significance and recovery potential. CTUIR initiated restoration activities to address existing habitat deficiencies as part of long-term watershed restoration plan.

In FY2007, CTUIR took a leadership role in the rectification of several fish passage barriers that were delaying the migration of adults ascending upstream to optimal spawning areas and impeding the movement of fish seeking optimal rearing areas and/or cooler water refuge areas during the summer months. West Birch Creek at the Cunningham property (RM 3.2) was the most significant passage barrier to be addressed in FY2007.

CTUIR subcontracted Andrus and Middel (2003) to complete a historical and present assessment of conditions in the Meacham Watershed to identify specific conditions affecting the status of juvenile salmonids. Three reaches with subsurface flow were identified in this watershed and three structural barriers were recommended to be modified or removed (Table 6). In FY2007, the three barriers were modified to improve passage in the Meacham Creek Watershed (Meacham Creek, RM 1.7, 20.2, and Camp Creek, RM 0.3) (Figures 15-17) as identified in the Meacham Creek Watershed Analysis and Action Plan (Andrus and Middle 2003).

Table 6. Meacham Watershed Fish Passage Barrier Descriptions FY2007

\begin{tabular}{|c|c|c|c|c|c|}
\hline Creek & RM & Structure & Latitude & Longitude & Elevation \\
\hline Meacham & 1.7 & Boulders & N4541.251 & W11821.294 & 2393 \\
\hline Meacham & 20.2 & Concrete Dam & N4528.828 & W11816.806 & 2700 \\
\hline Camp & 0.3 & Concrete Dam & N4534.583 & W11819.136 & 2350 \\
\hline
\end{tabular}

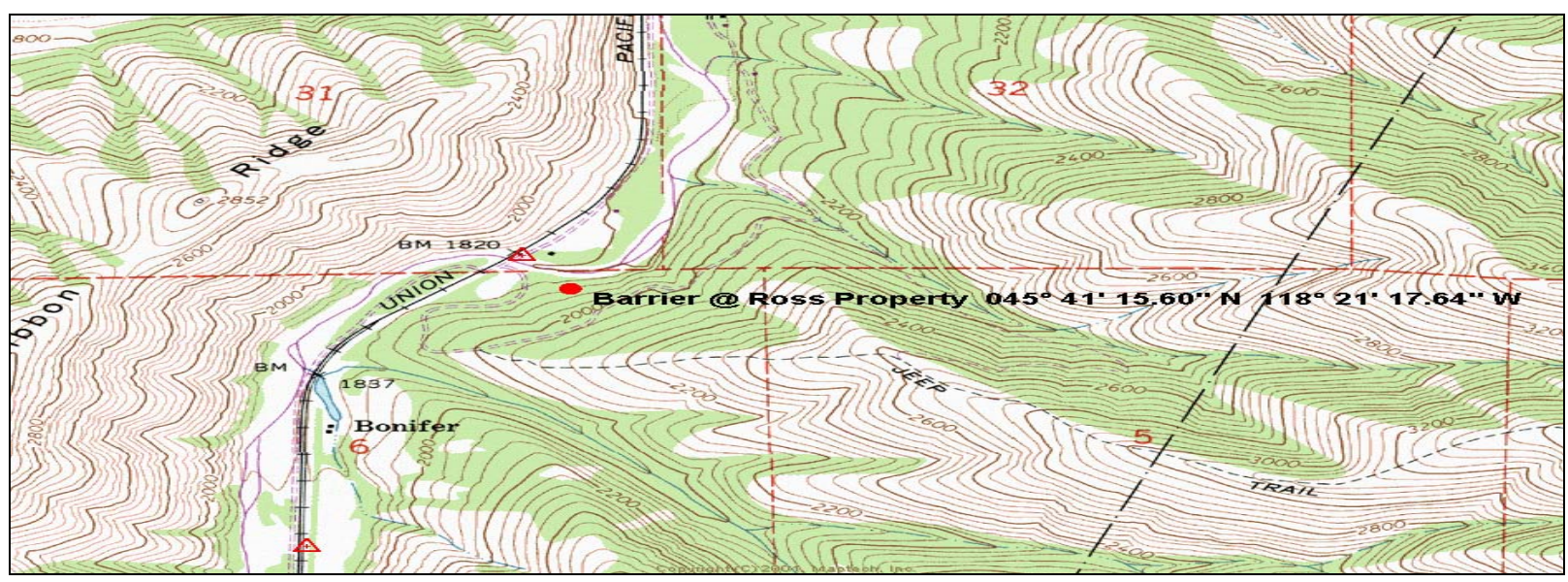

Figure 15. Topographic Map Showing Location of Fish Passage Rectification Project at RM 1.7 of Meacham Creek 


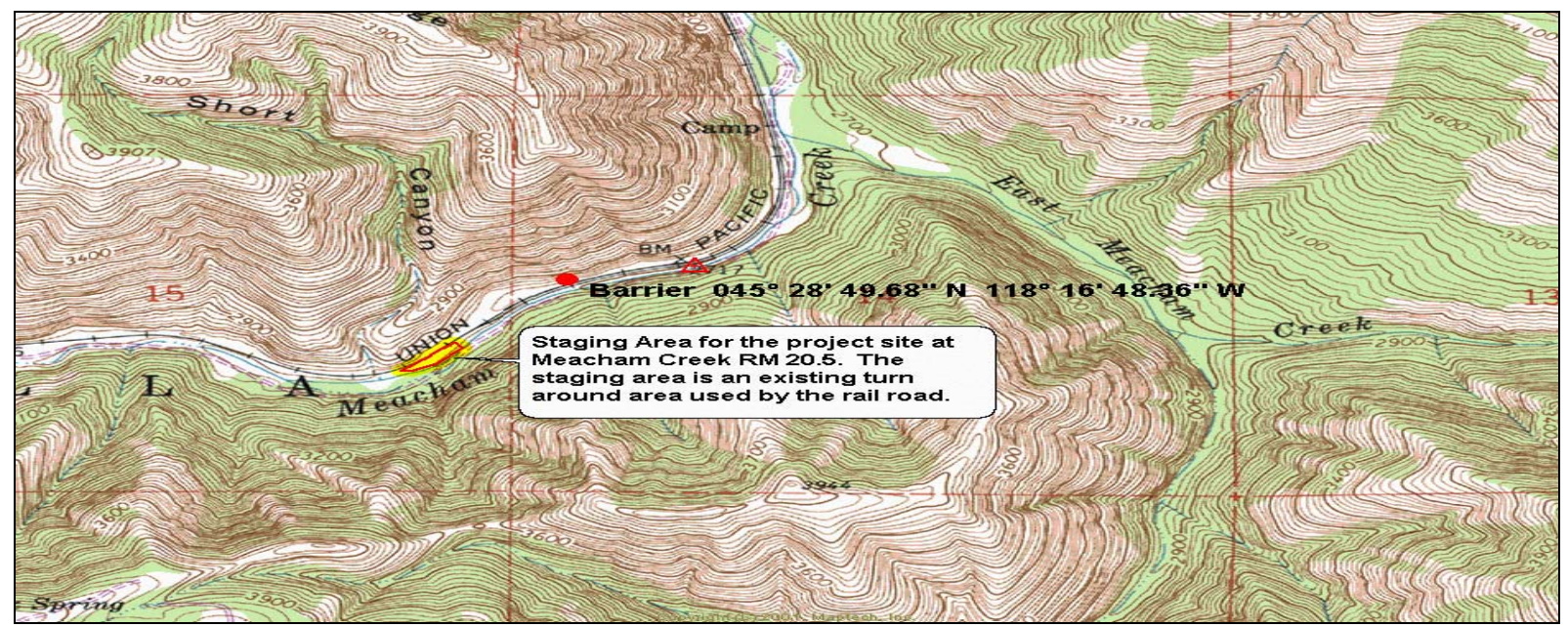

Figure 16. Topographic Map Showing Location of Fish Passage Rectification Project at RM 20.2 of Meacham Creek

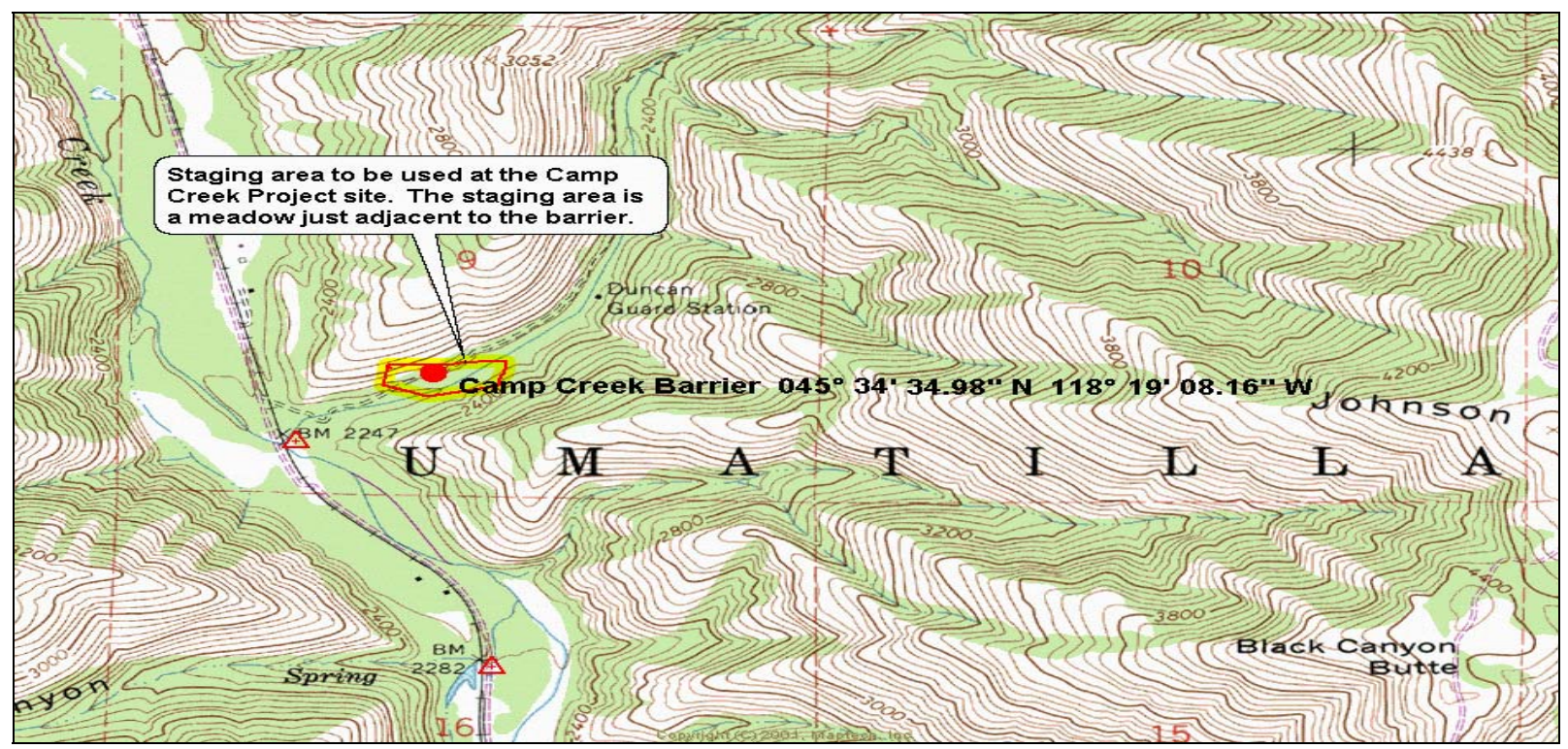

Figure 17. Topographic Map Showing Location of Fish Passage Rectification Project at RM 0.3 of Camp Creek

An additional site was rectified on Greasewood Creek, RM 0.4 in October 2007. The overriding purpose of the fish passage barrier rectification projects was to improve fish passage and approach natural morphology of the stream channel.

CTUIR requested that its Meacham passage barrier rectification proposal be considered under the Oregon Department of State Land's (DSL) general authorization process and the USACE's Standard Local Operating Procedures for Endangered Species program. CTUIR submitted a supplemental BA, Fish Passage Barrier Rectification: Meacham, Camp Creeks, Biological Assessment, April 10, 2007 (Hoverson 2007), regarding the barrier rectification project to the appropriate sources to supplement a Joint Permit Application (JPA). The Biological Assessment (Hoverson 2007) provides details of impact determinations. Representatives from the CTUIR Cultural Resource program conducted preliminary surveys of the project areas and granted 
official clearance to proceed with implementation activities. CTUIR UAFEP prioritizes the involvement of Cultural Resource staff to ensure that cultural interests are protected and preserved in a manner consistent with CTUIR policy.

Key objectives of all the barrier rectification projects are to:

- Improve access for salmonids to stream headwater areas and cool water refuges

- Increase the quantity and quality of accessible salmonid habitat

- Approach historical free-flowing migratory corridor through passage improvement

- Approach natural stream slope, function and appearance

- Improve connectivity for populations of listed salmonid species to improve genetic exchange/integrity to improving fitness and long term survival capability

- Increased salmonid population dynamics and carrying capacity of preferred species

- Fulfill tasks identified in restoration plans by addressing limiting factors

- Improve survival rates by reducing stressors on salmonids

- Reduce impacts to various stream biota associated with structural passage barriers

During passage rectification and habitat enhancement projects, fish relocation operations conducted by CTUIR are authorized under various pre-existing permits which allow the capture and handling of listed fish species for scientific purposes. CTUIR has a very experienced and certified crew including an on-site project leader with 15 years of experience working with naturally produced Pacific Northwest salmonids. CTUIR uses well-maintained fish capturing gear and techniques that minimize impacts on fish health. Fish capturing crews use nets to make as many passes as necessary in attempt to remove $100 \%$ of the fish from the work sites.

The engineering design phase for the barriers in the Meacham Creek Watershed was subcontracted and completed in the fall of 2006 by Anderson-Perry Associates. The contractual agreement for the modification of the structures was between Steve Lindley Contracting and CTUIR. These three structures took 10 days to rectify. Fisheries staff were on the project sites during the entire implementation process to monitor contracted, permitted activities and protect fish and wildlife resources. At all three of these sites, step heights were targeted to fall within the six inches or less guideline as established by the ODFW. Specific details about each barrier follow.

Meacham Creek RM 1.7: This barrier (Figure 18) consisted of a series of large boulders cabled together in a line across the channel, creating a step height of $0.5 \mathrm{~m}(1.6 \mathrm{ft})$. The dimensions were $28 \mathrm{ft}$ across by $3 \mathrm{ft}$ thick. The structure was located about $300 \mathrm{~m}$ (984 ft) downstream from the first railroad bridge, approximately $150 \mathrm{~m}$ (492 ft) east of the railroad grade and $100 \mathrm{~m}$ (328 $\mathrm{ft}$ ) downstream from a water quality gauging station. This formation of this barrier was constructed in the late 1980s as part of a habitat project that was attempting to increase holding areas by creating more pool cover. The scope of work included the following: (1) utilizing hand tools to cut cable to free up a large boulder located in the middle of the structure; (2) relocating the boulder to an adjacent area where it no longer impedes fish passage; and (3) planting trees in the adjacent riparian zones. No heavy equipment was required to rectify passage at this particular site as per landowner request, and there was minimal, if any disturbance. An aquatic habitat inventory survey was conducted prior to barrier removal. Figure 19 shows the project site post barrier removal. 


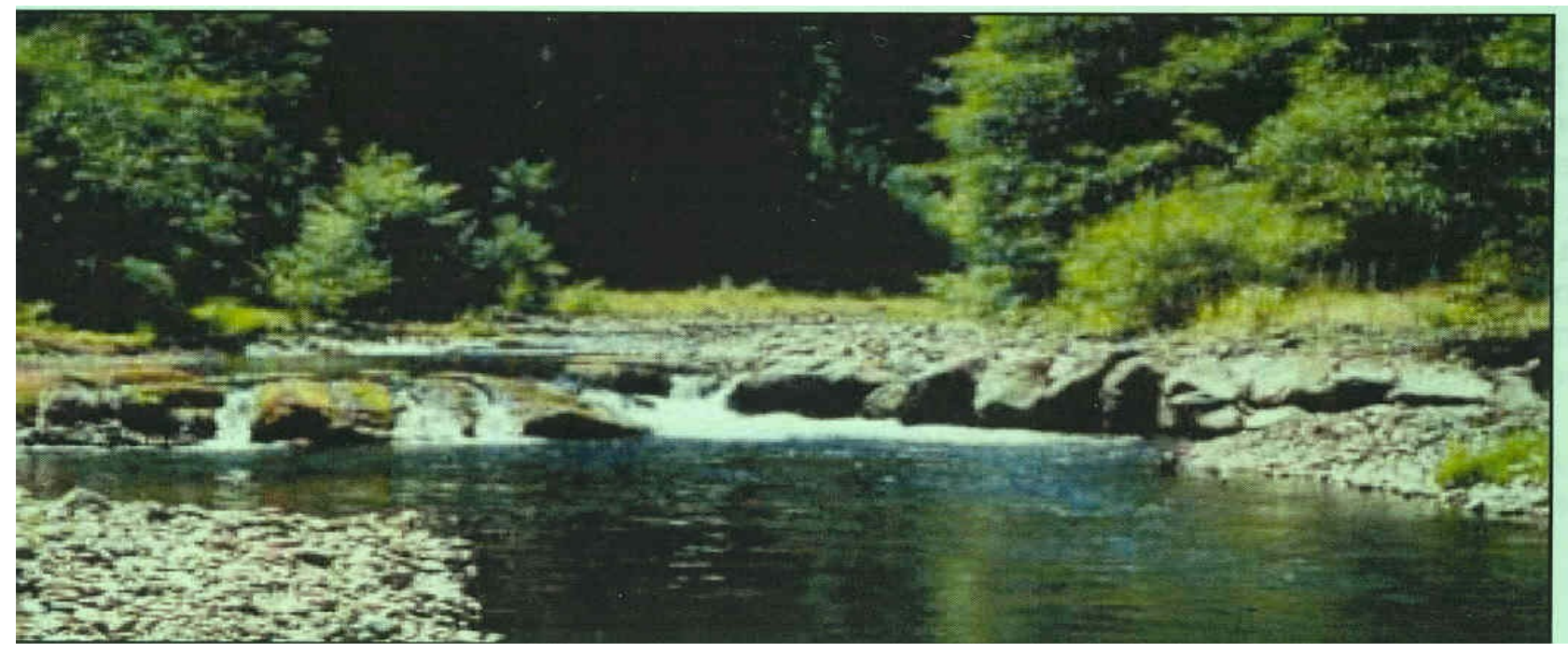

Figure 18. Meacham Creek Fish Passage Barrier RM 1.7, Prior to Rectification

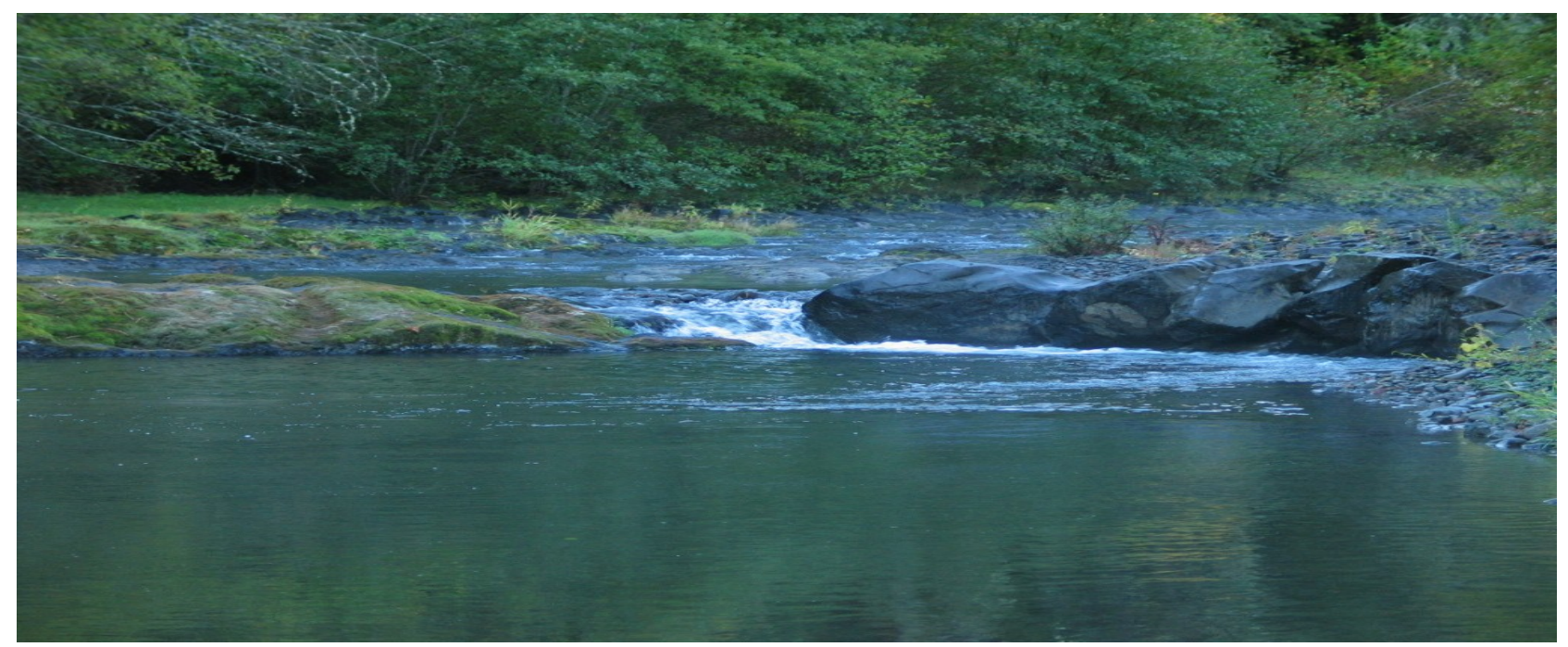

Figure 19. Meacham Creek Fish Passage Barrier RM 1.7, Post Rectification

Meacham Creek RM 20.2: This barrier consisted of a concrete dam (Figure 20) measuring $57 \mathrm{ft}$ across and $2 \mathrm{ft}$ thick. Figure 21 shows the creek post barrier removal. The dam was set within $15 \mathrm{~m}$ (49 ft) of the adjacent railroad grade and was a relic from the early 1900s steam locomotive era. It created a step height of $0.5 \mathrm{~m}$ (1.6 ft). The scope of work for site activities included: (1) capturing fish located within $100 \mathrm{~m}$ (328 ft) of the work site and relocating them to adjacent upstream areas of the creek; (2) installing blocknets in the stream to prevent re-entry of fish (Figure 22); (3) using a concrete saw to remove the top 1-3 inches from a $10 \mathrm{ft}$ portion of the dam to improve passage at moderate flows; (4) removing an additional 2 inches from the middle of the dam to improve passage at low flows; (5) using a dump truck to remove concrete from the area for proper disposal; (6) installing two cross vanes with rootwads using a track hoe for restoring proper grade, and (7) planting trees and seeding in the adjacent riparian zone and disturbed areas. One vane was constructed upstream and one downstream from the concrete structure. An aquatic habitat inventory survey was conducted prior to barrier removal. 


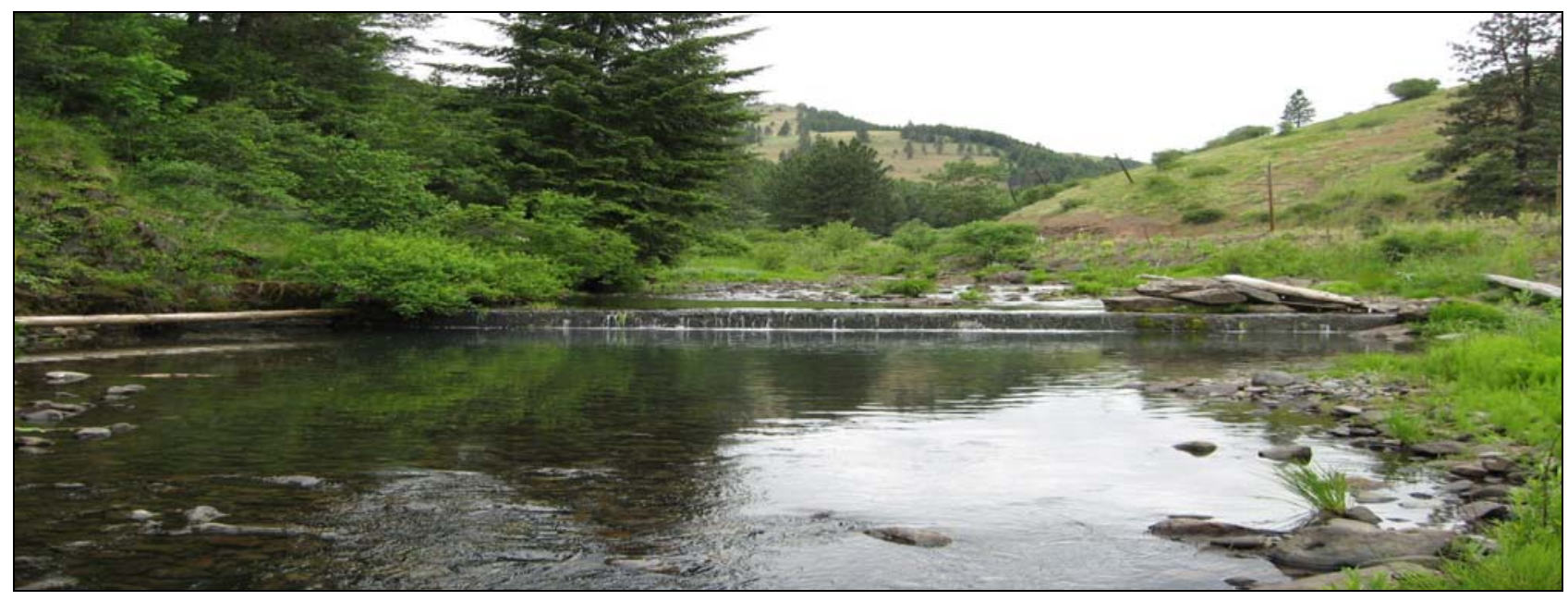

Figure 20. Meacham Creek Fish Passage Barrier, RM 20.2 Prior to Rectification

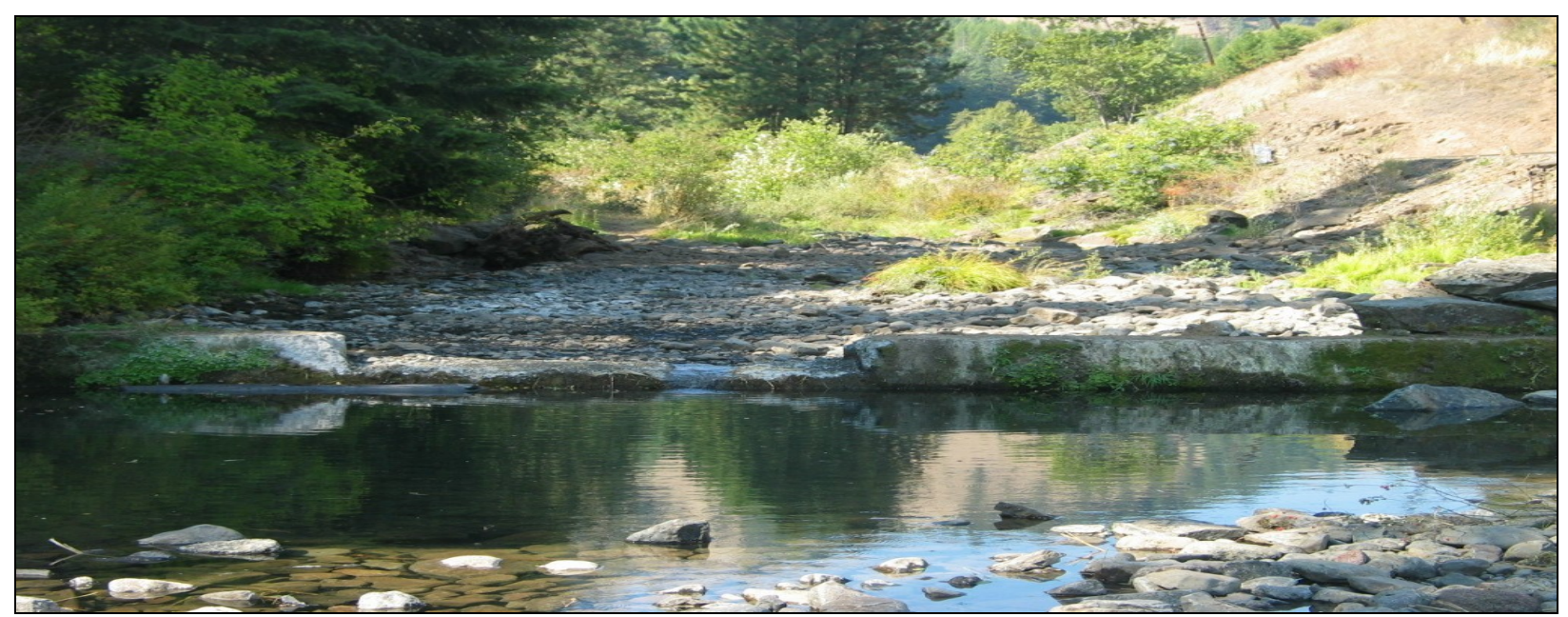

Figure 21. Meacham Creek Fish Passage Barrier, RM 20.2 Post Rectification

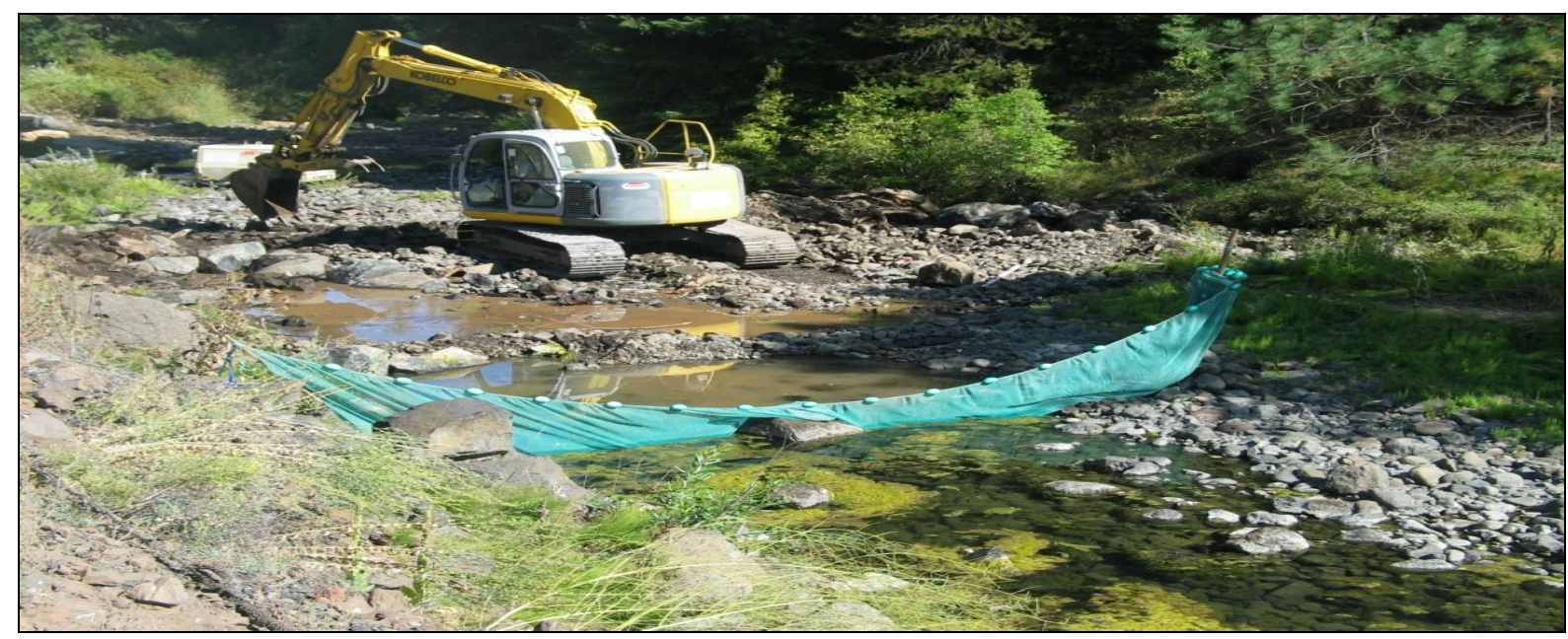

Figure 22. Meacham Creek RM 20.2 Construction of Upper Cross Vein Showing Site Isolation Method

CTUIR Umatilla Anadromous Fisheries Habitat Project NPPC Project\# 1987-100-01 
Camp Creek RM 0.3: This barrier (Figure 23) consisted of a concrete dam measuring $33 \mathrm{ft}$ across and $2 \mathrm{ft}$ thick. This structure was in place for more than 50 years and was built as part of a gravity-fed irrigation system which delivered water to adjacent fields to improve grazing conditions for cattle. Prior to rectification, it presented a concern for passage, but was not a complete barrier due to increased flows over the crest, an adequate jump pool, and/or established braiding around the structure. The barrier was considered to be a complete barrier during low flow periods as step height measurements approached $1 \mathrm{~m}(3.3 \mathrm{ft})$ with little flow over the crest. Work at this site included: (1) capturing fish from the work zone prior to construction and relocating them upstream; (2) capturing and relocating fish from the 2 creek crossings that were within the path of the implementation equipment; (3) setting blocknets upstream and downstream of the work zone to prevent organisms from moving back into the areas where fish removal occurred; (4) removing the top two feet from the dam using a concrete saw; (5) using a dump truck to remove concrete from the area for proper disposal; (6) using a track hoe to incorporate woody debris and construct one cross vane upstream from the concrete structure, and (7) retaining mature growth and planting trees and/or seeding the adjacent riparian zone and disturbed areas. An aquatic habitat inventory survey was conducted prior to barrier removal. Figure 24 shows the site after rectification of the barrier.

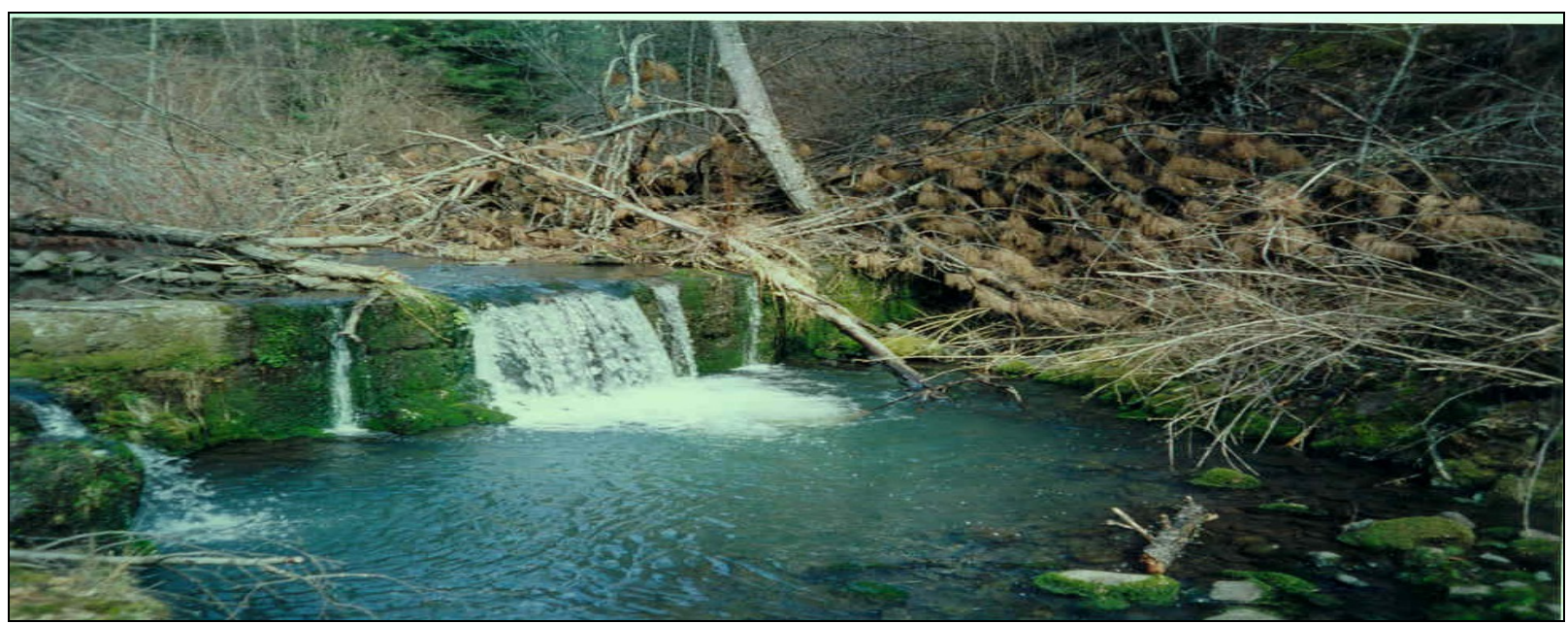

Figure 23. Camp Creek Fish Passage Barrier, RM 0.3 Prior to Rectification

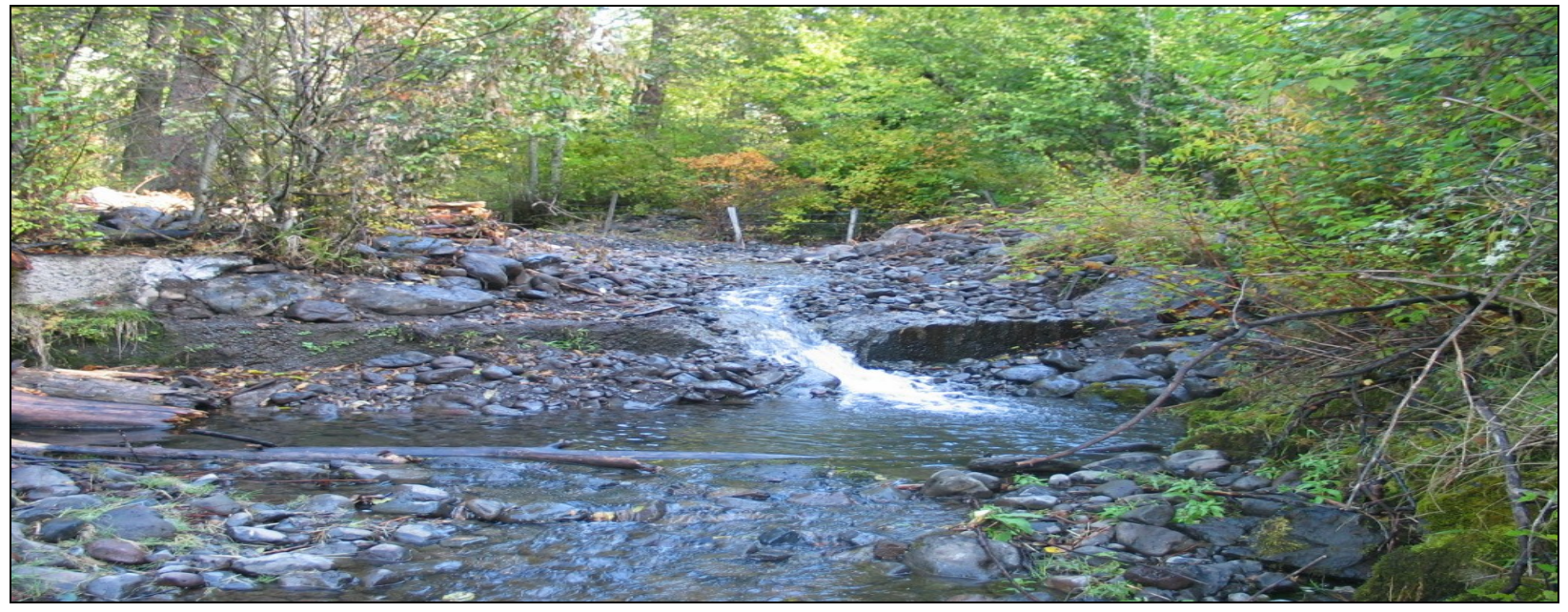

Figure 24. Camp Creek Fish Passage Barrier, RM 0.3 Post Rectification 
Greasewood Creek RM 0.4: This barrier (Figure 25) was a concrete dam measuring $10 \mathrm{ft}$ across and $2 \mathrm{ft}$ thick. Wooden flash boards were used to manage water levels under different flow regimes. This dam was utilized by a private ranch in the past for irrigating cattle pastures but became obsolete. The landowner granted CTUIR permission to remove the final stop-log that the landowner had unknowingly left in place following deconstruction of the irrigation pipeline. Figure 26 shows the Greasewood Creek site at RM 0.4, after rectification of the barrier, which occurred on October 26, 2007.

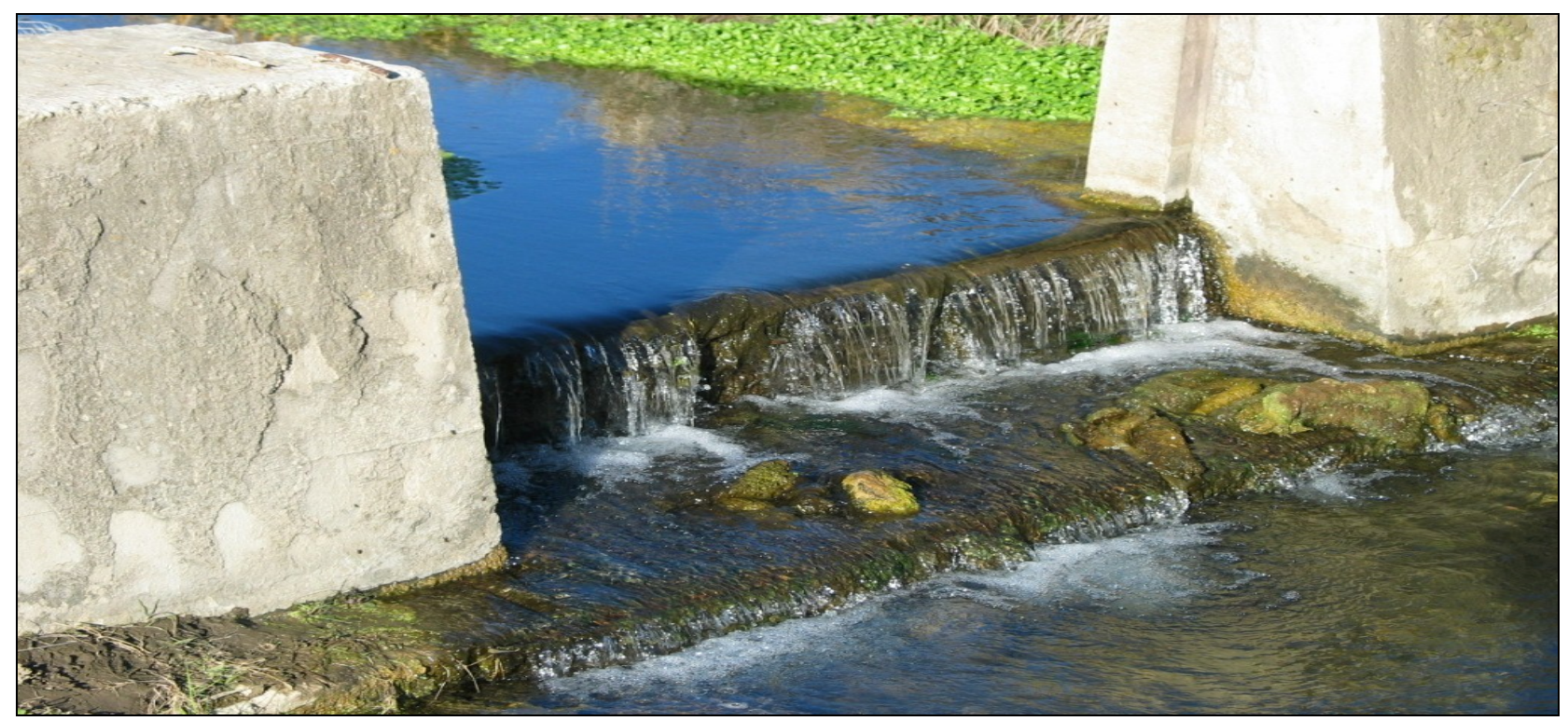

Figure 25. Greasewood Creek Fish Passage Barrier, RM 0.4 Prior to Rectification

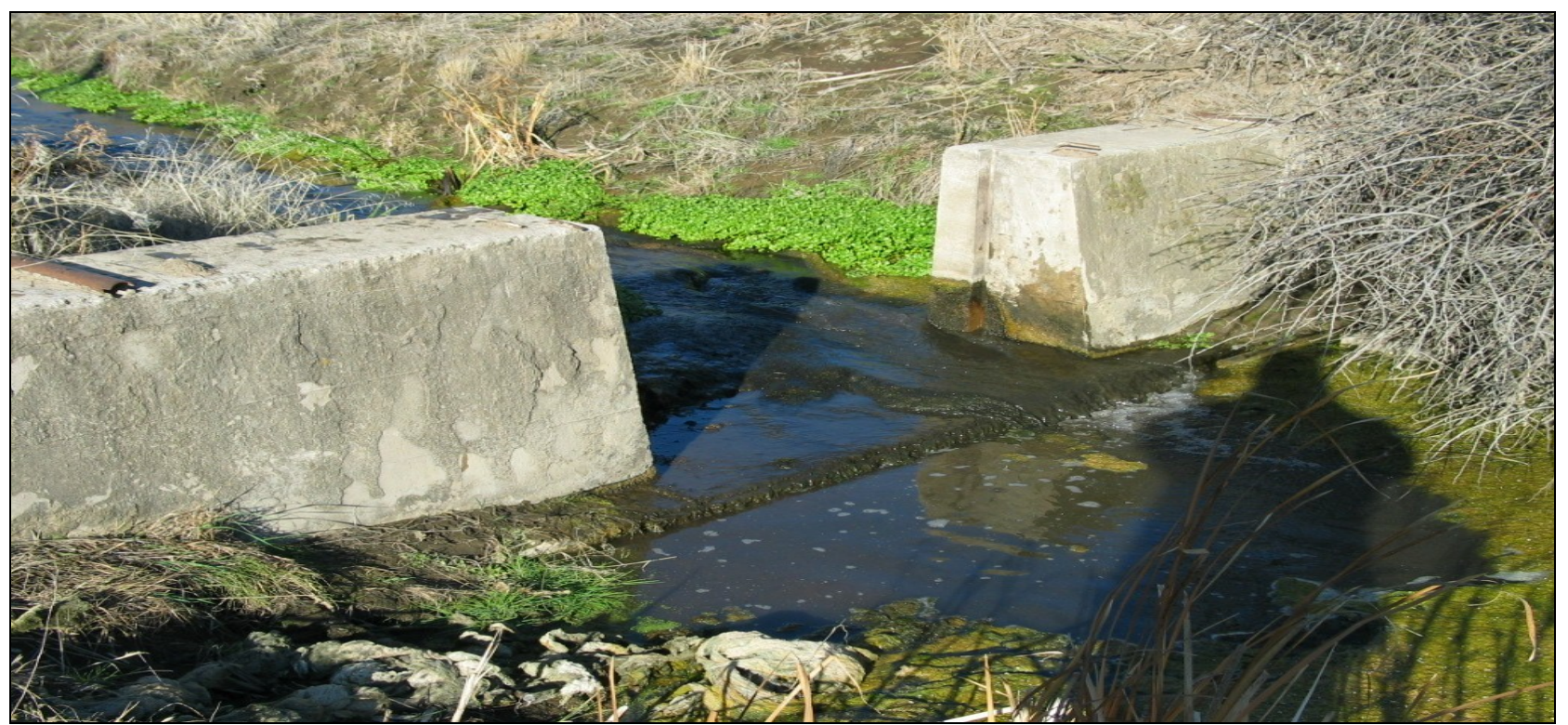

Figure 26. Greasewood Creek Fish Passage Barrier, RM 0.4 Post Rectification 
West Birch Creek, RM 3.2. CTUIR worked with Bio Engineers Inc. to design a roughened channel remedy to address passage concerns (Figure 27). This habitat restoration project was designed to enhance migratory fish passage conditions by incorporating stream channel roughness to restore proper gradient and reduce step height at a road bridge crossing (box culvert). The bridge (Figure 28) had been identified as a problem for fish passage in a high priority area for migratory salmonids. The bridge was constructed in 1956-57 to allow access to the other side of the creek for vehicles and sheep. Over time, the box culvert downcut the streambed and created a step height of $1 \mathrm{~m}$ (3.3 ft). The dimensions of the structure are $24.5 \mathrm{ft}$ wide, $21.5 \mathrm{ft}$ long, and $9.0 \mathrm{ft}$ high. The walls and floor of the culvert are made of concrete. The box culvert design and flat concrete floor created an undesirable state of shallow, uniform, sheetflow during the summer months, posing a passage problem for migrating fish. An additional concern was the creation of a velocity barrier during higher flows, due to the uniform design which concentrates hydraulic energy. To rectify this issue, 13 baffles were affixed to the floor of the box culvert Figure 29 shows the bridge post rectification.

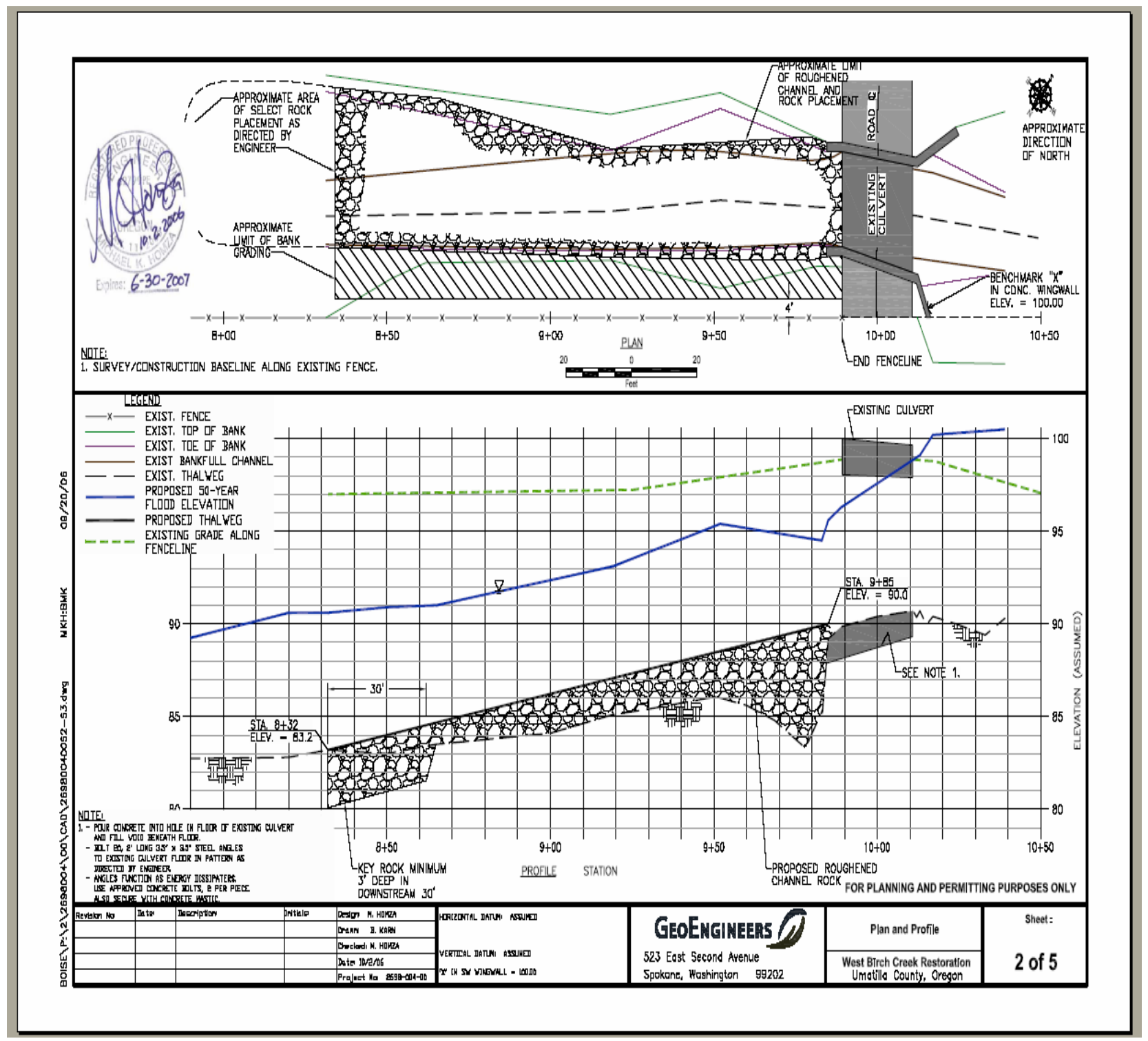

Figure 27. Blueprint Plan and Profile, Cunningham Bridge, West Birch Creek, RM 3.2 
Work at the Cunningham site, West Birch Creek, RM 3.2, included the following actions:

(1) Conducting an aquatic habitat inventory survey prior to work.

(2) Capturing fish with nets from the work area, and relocating them upstream. Data from the fish capturing exercise was used to document species composition and estimate abundance. This data will be beneficial for biological monitoring activities when used to compare data sets from the pre-implementation baseline versus post-project inventories to quantify fish response to restoration activities.

(3) Isolating the work site by using an incremental dewatering process, which was achieved by operating a generator and intake pump located just upstream from the box culvert (Figure 30) such that the water was diverted around the work site and re-entered the channel below the work zone. Isolating the work area from flowing water was the most beneficial option to fish and wildlife because of the extensive in-channel implementation activity required to roughen the channel.

(4) Using blocknets to prevent re-entry of fish during the implementation period.

(5) Modification of the floor of the bridge structure was done by utilizing hand tools to set a series of angled baffles onto the floor using bolts supplemented with concrete glue to eliminate gaps caused by unevenness. The intent of the baffles is to dissipate energy and concentrate flows into a smaller area to increase the depth of the water during low flow periods to improve passage.

(6) Pouring concrete into a small hole that has formed in the culvert floor and into a void at the base of the culvert. This imperfection in the structure was formed by erosional forces over time and created a fish trap that had potential to isolate and strand fish underneath the concrete floor.

(7) Completing the channel roughening process work by packing the creek with fine substrates in order to fill gaps and decrease permeability. This allowed water to persist at the stream surface to mimic natural sorting processes and to achieve a functional thalweg and flow pattern.

(8) Securing the streambed by slowly pumping water onto the altered channel until a satisfactory level of flow stability was achieved. Natural stream flow was then allowed to access the surface of the rehabilitated reach by natural means.

(9) Targeting step heights to comply with the 6 inches or less standard guideline as established by the ODFW.

(10) Conducting an aquatic habitat inventory survey prior to implementation.

(11) Sloping the banks from 90 degrees to a 45 degree angle prior to planting and re-seeding;

(12) Planting and re-seeding with native grasses and shrubs. 


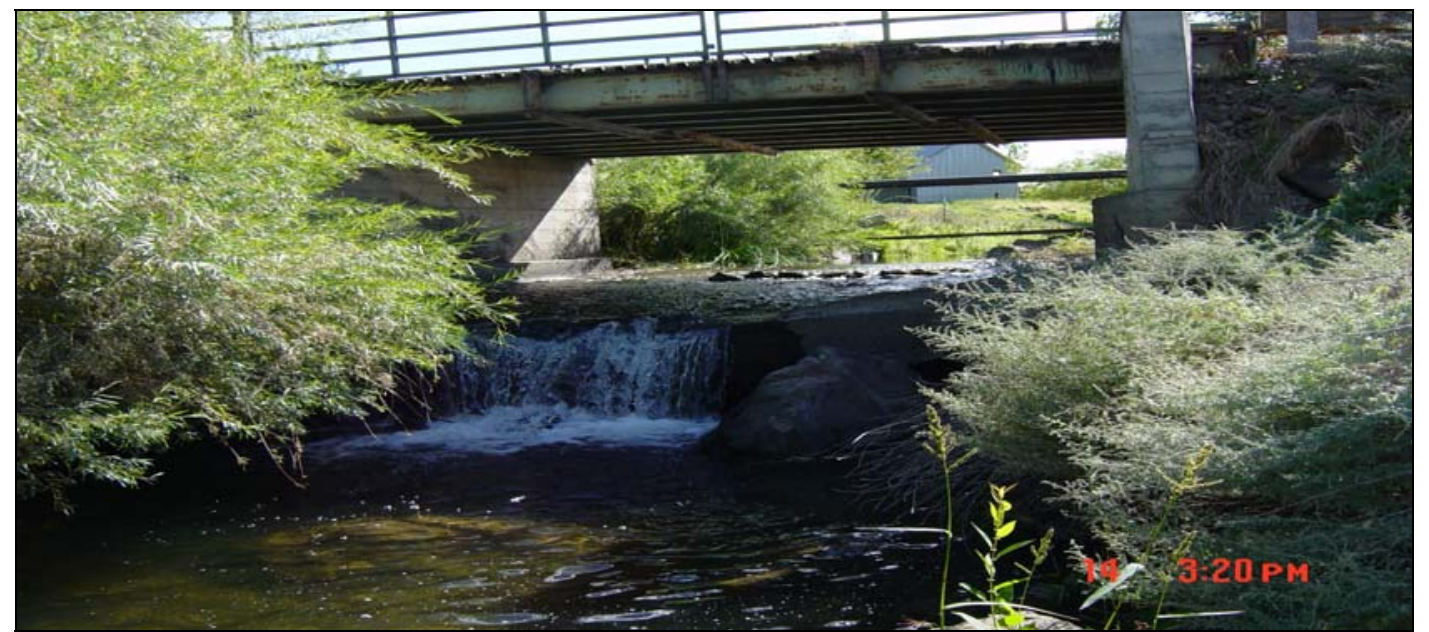

Figure 28. Cunningham Bridge on West Birch Creek, RM 3.2 Prior to Rectification

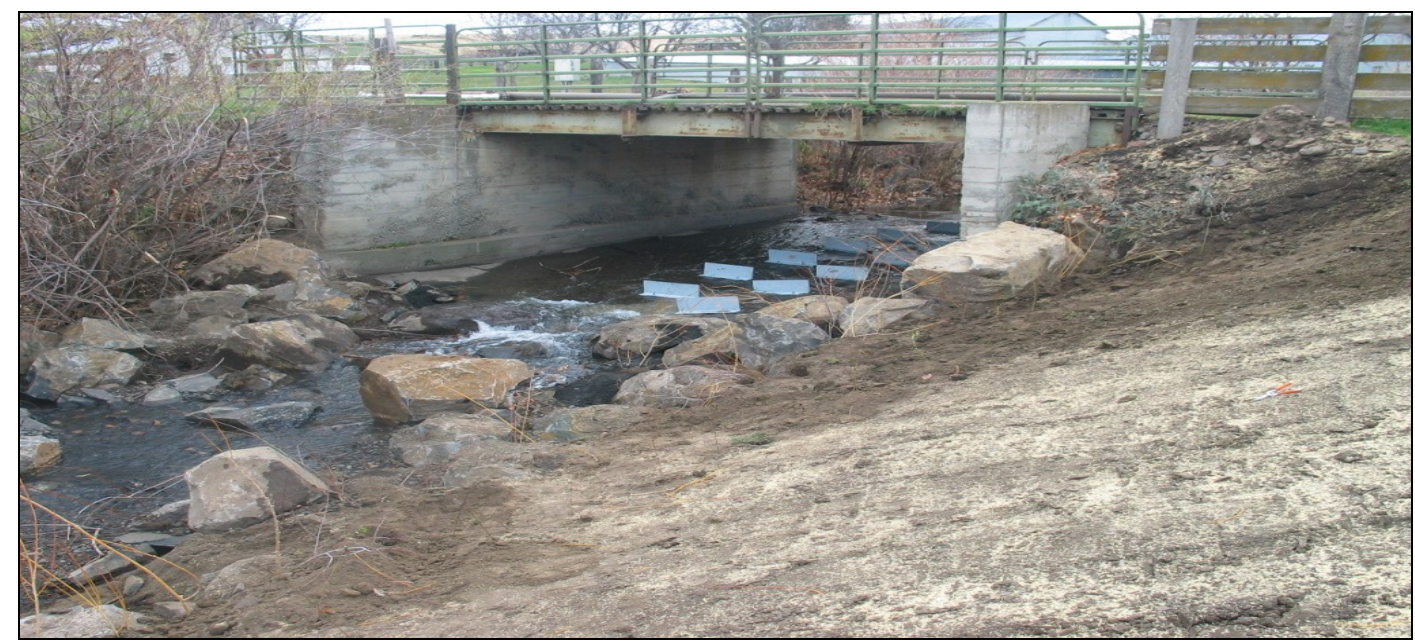

Figure 29. Cunningham Bridge on West Birch Creek, RM 3.2 Post Rectification

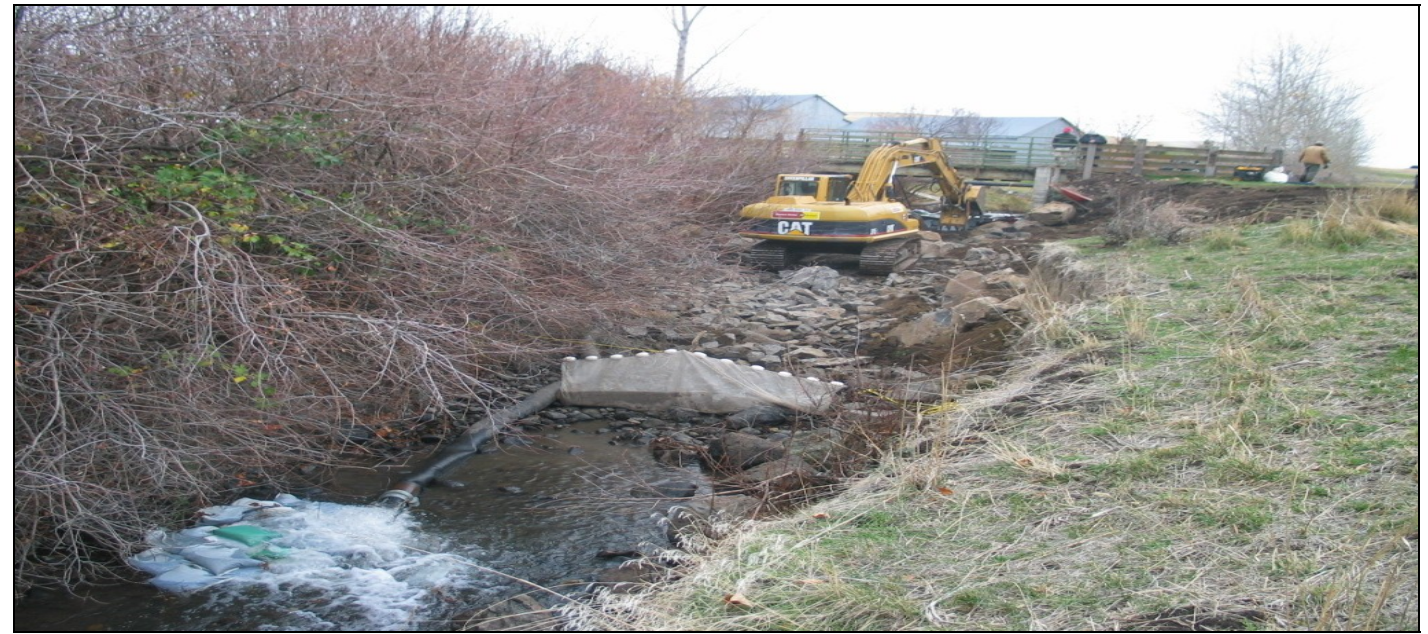

Figure 30. Dewatering and Site Isolation Method, West Birch Creek, RM 3.2, Cunningham Bridge 


\section{Cumulative Effects}

Meacham Creek Watershed

The Meacham Watershed restoration plan involves strategies to restore several diverse components of the basin's ecosystem. A variety of habitat improvement activities are part of the general Meacham Creek Watershed Enhancement Plan as recommended by Andrus and Middel (2003). These are: 1) restoration of channel sinuosity on lower Meacham Creek via levee setback, 2) remediation of manmade obstacles to fish passage, 3) excavating deep, complex pools, 4) fireproofing land near the mouth of North Fork Meacham Creek, 5) fencing portions of the stream, 6) re-establishment of stream-side vegetation, 7) replacement of a road bridge, and 8) increasing off-channel rearing habitat.

The main road bridge was replaced in 2005, the large wood implementation phase and riparian plantings occurred in the fall of 2006, and the passage phase was completed in September 2007. The beneficial aspects resulting from these restoration strategies are designed to be achieved with only minor short-term disruption while dramatically improving conditions over the long term.

West Birch Creek

We expect a desirable response of the vegetative component in addition to many beneficial long term responses of various fish and wildlife species in the action area. We foresee a future channel that allows improved mobility for fish, and improvements in the structural integrity of the box culvert as well the functionality of the structure at a wider variety flows. We also project improvements to instream and riparian cover and associated characteristics. Active monitoring of the site will quantify the degree of change and help to determine what additional steps CTUIR may need to take to mitigate and adaptively manage this project area for achieving optimal long term results.

Modification of the Cunningham Bridge is CTUIR's initial phase for improving conditions and is the first step of a long-term co-management plan (with ODFW) aimed at improving conditions for steelhead trout in this important tributary. Beneficial results will be magnified upon the completion of neighboring Hoeft Dam (RM 2.7) in FY2008. CTUIR expects the passage improvement phase of the Birch Creek Watershed restoration effort to directly contribute results in the form of increased salmonid carrying capacity and adult returns and improved watershed quality and function.

\section{Greasewood Creek}

The barrier removal conducted at Greasewood Creek was combined with a riparian fencing project and an NRCS riparian planting project. All of these actions will help improve the habitat status on this severely degraded creek. CTUIR has also seeded the lower reaches of the riparian area with native grasses and planted native trees. These reaches are held under the protection of long term easements.

\section{Installation of Two Wells at B\&G Resources Property for Off-Channel Livestock Watering}

During FY2007, CTUIR drilled two wells at B\&G Resource's property adjacent to the Umatilla River (RM 40) west of Pendleton, Oregon, to provide off-channel watering for cattle outside of 
the fenced riparian zone which is enrolled in the United States Department of Agriculture's CREP program.

B\&G Resources is located on lands where a large Corps of Engineers dam was removed abruptly via dynamite by disgruntled sportsmen in the 1950s. The abrupt, unprofessional demolition removal of the dam caused significant channel incision due to erosional forces and left 30 -ft high terraces, most notably upstream (Figure 31) of the dam site.

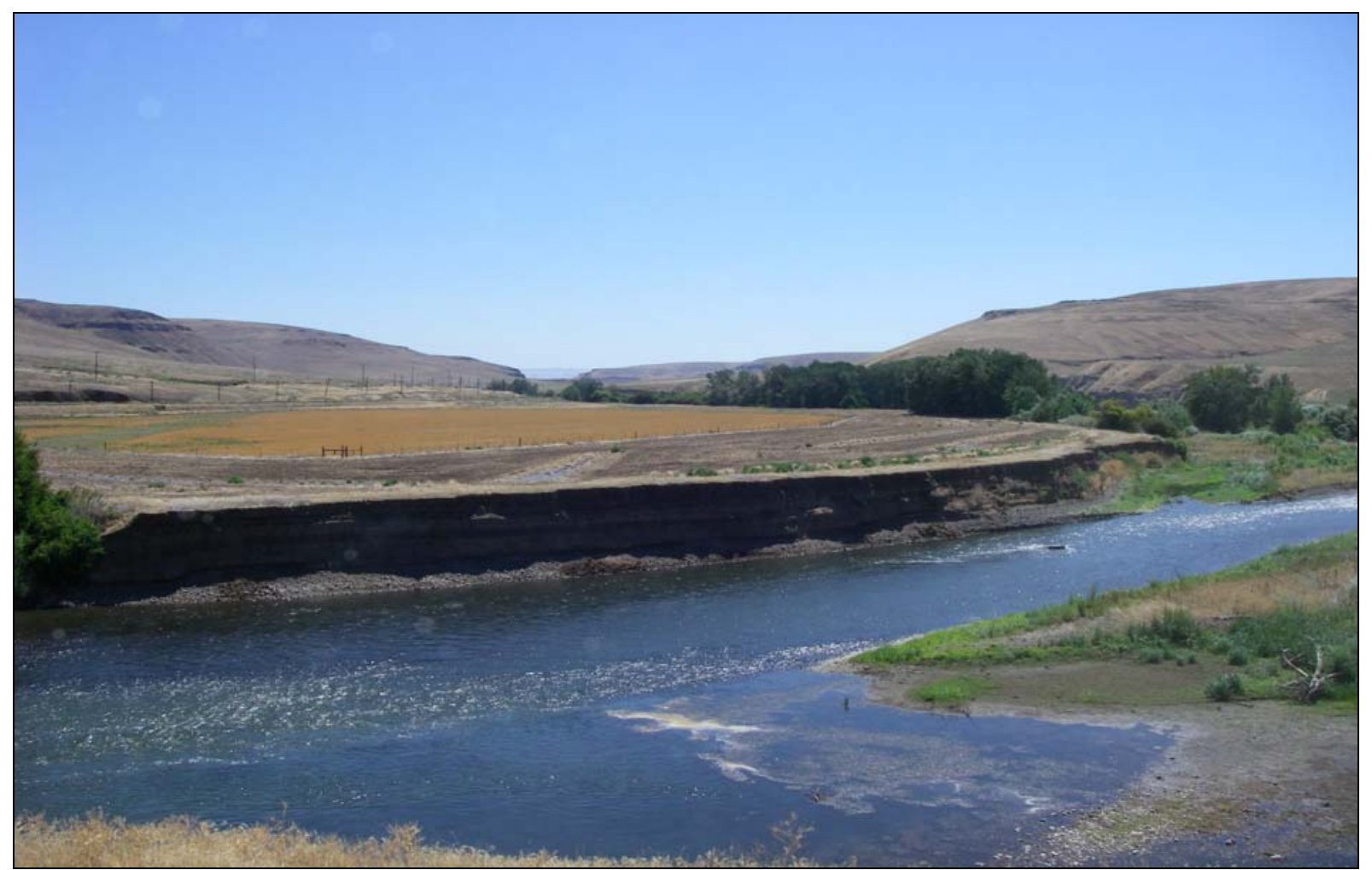

Figure 31. Umatilla River RM 40, Showing Severely Incised Channel and Bank Erosion

The terraces are largely devoid of water due to the distance from the water table and arid climate of this location. CTUIR is planning to reestablish native grass and tree species upon the terraces in cooperation with NRCS and FSA in FY2009. Figure 32 shows B\&G Property characteristics including two well location sites and four CREP tracts designated by the letters A-D. The CREP sites are intended to help provide improved riparian habitat conditions along the Umatilla River (RM 38-41). Drilling occurred in January 18, 2008 at two locations on the B\&G property (Figure 33 and 34). The addition of solar panels and water troughs will also be accomplished in FY2008 to complete the well installation and the off-channel water source process. In previous years, CTUIR gathered baseline aquatic habitat and fish data in this area (CTUIR 1995). 


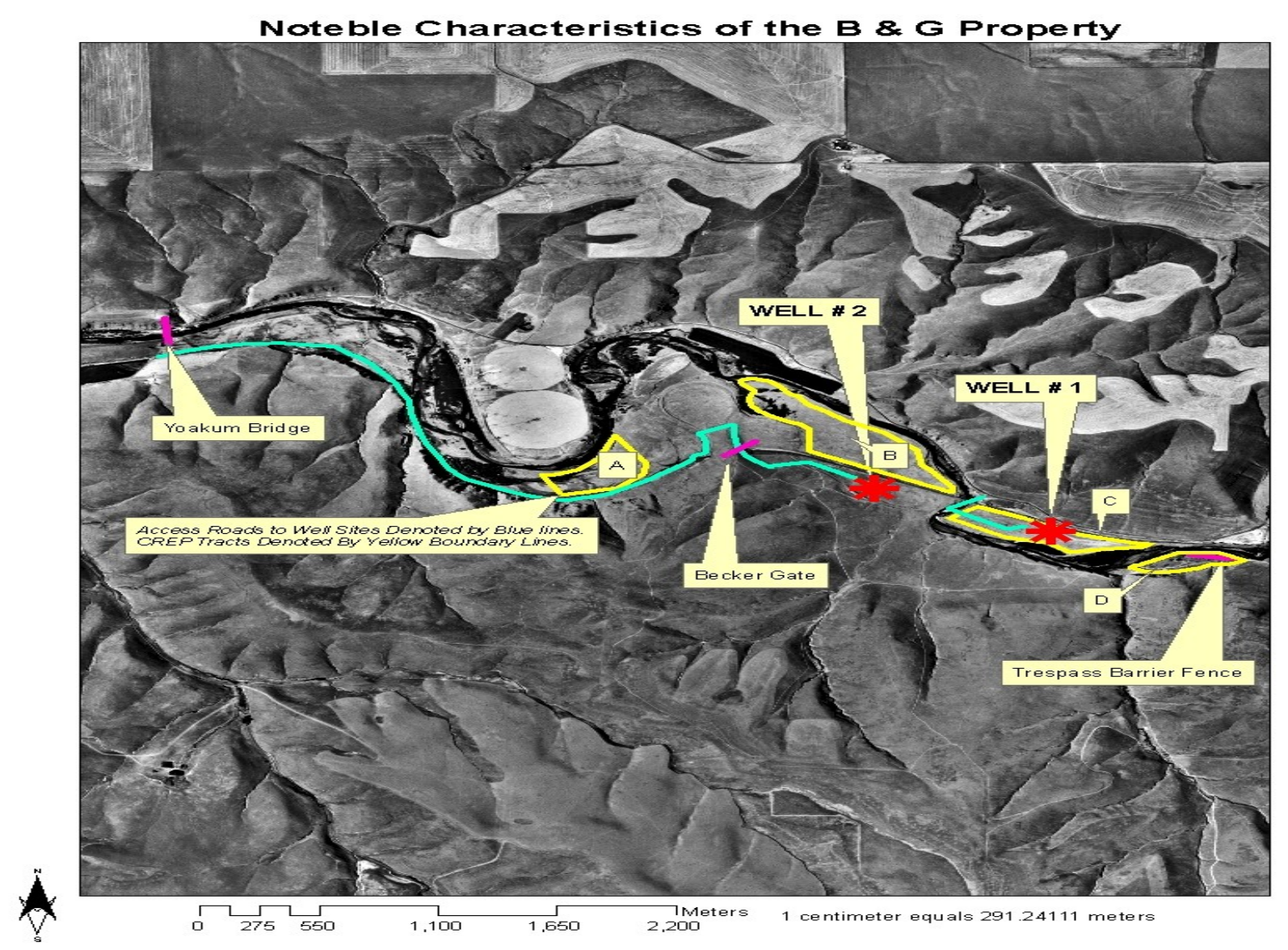

Figure 32. Well Locations and CREP Tracts, Umatilla River RM 40

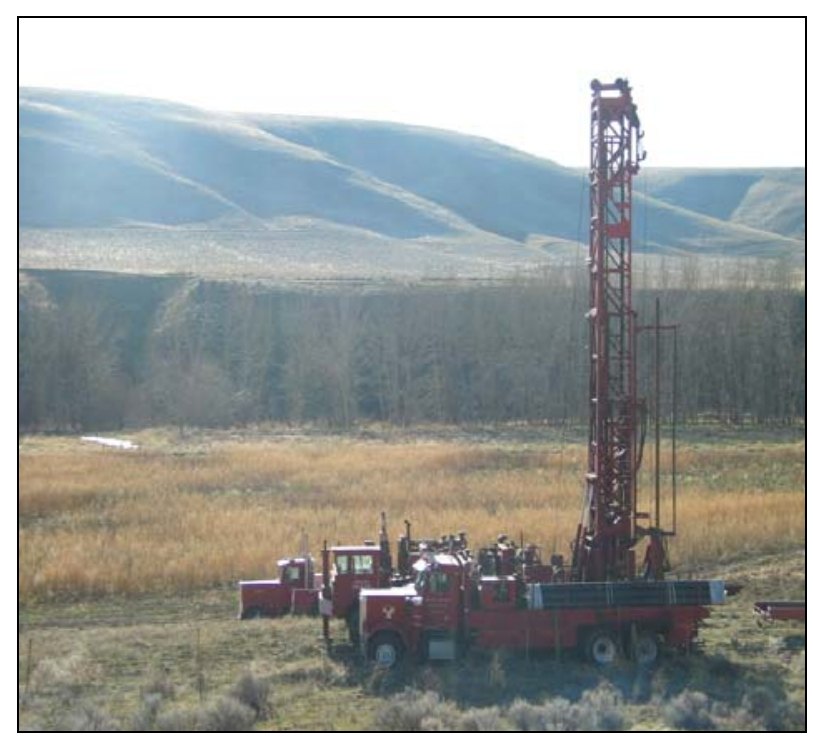

Figure 33. Drilling Well \#1

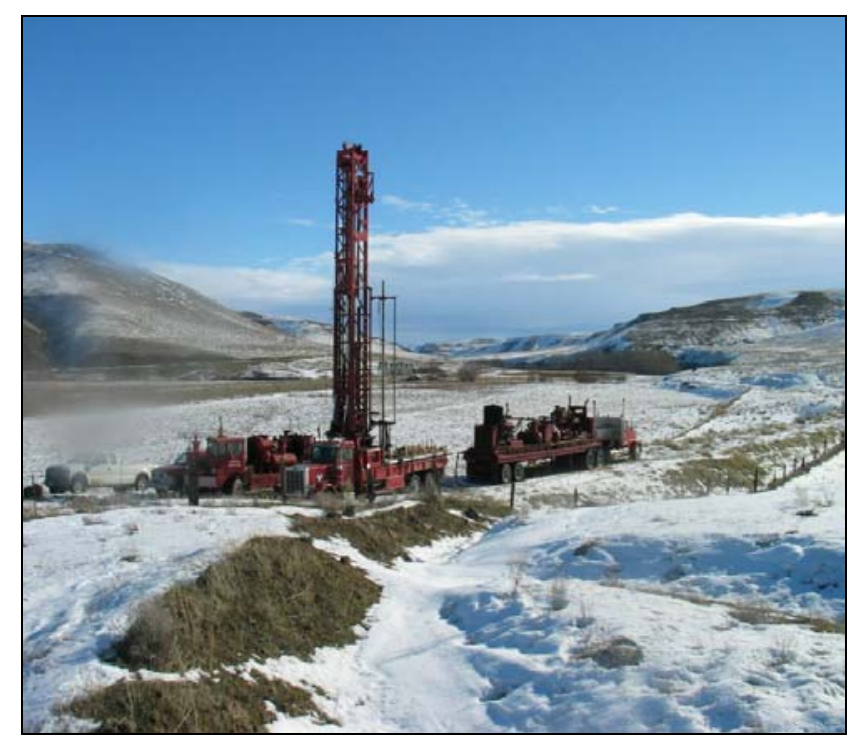

Figure 34. Drilling Well \#2 


\section{SUMMARY AND CONCLUSIONS}

The CTUIR UAFHP completed 8 habitat enhancement projects and numerous adaptive management and monitoring projects in the Umatilla River Basin. In addition, work continued at 27 pre-existing long-term easements with 23 landowners. Project highlights included implementation of 5 fish passage rectification projects in Meacham Creek, West Birch, Camp Creek and Greasewood Creek. A total of 1275 saplings and 130 pounds of native grass seed were planted, and eight water gaps, two miles of riparian fencing and two off-channel livestock watering wells were developed.

A principal strength and focus of the CTUIR UAFHP project is the ability to work cooperatively with the various entities throughout the restoration process. Strong partnerships increase the magnitude and frequency of success and often facilitate additional project opportunities.

Professional and effective networking efforts provide opportunities to recruit specialized experts in the profession to jointly develop project strategies to strengthen the result of restoration and enhancement actions.

The UAFHP project provides technical assistance to other entities to assist in the development of associated projects. The CTUIR UAFHP program will continue to work with project partners in the basin, to achieve successful improvements in watershed conditions, and facilitate recovery of ESA-Listed fish stocks by accomplishing unprecedented quantity and quality of results.

The CTUIR UAFHP hypothesizes that both ecological and physical forces currently limit salmonid production in the Umatilla River Basin and that the relationship between physical habitat conditions, ecological conditions, and salmonid abundance will improve in sites that receive habitat treatments. Post-treatment monitoring is an important component of the habitat restoration process and is vital towards determining measurable results of restoration actions and identifying trigger-mechanisms responsible for instigating positive change.

Recognition of the unique characteristics of each project site should be considered in conjunction with landowner parameters when selecting the most effective, site-specific habitat restoration plan. A plethora of management strategies have been successfully applied in effort to reestablish the salmonids to self sustaining levels. We expect exponential response of salmonid populations once habitat deficiencies are addressed and improved. We believe a positive correlation between habitat improvement, salmonid density, and fitness levels will shift the status of ESA-Listed species towards a safer level of sustainability in the Umatilla River Basin.

Project success is ultimately determined by technique applicability, accurate implementation, effective monitoring and timely adaptive management. The CTUIR UAFHP is recognized as experts in the discipline of fish habitat restoration in this geographic region and strives to maintain this status. 


\title{
SUMMARY OF EXPENDITURES
}

\author{
CTUIR UMATILLA ANADROMOUS FISHERIES ENHANCEMENT PROJECT \\ FY2007 BUDGET \\ Contract Period: February 1, 2007 - January 31, 2008 \\ Project \# 1987-100-01 - Contract 32047
}

BPA

\begin{tabular}{llr}
\multicolumn{2}{l}{ PERSONNEL SERVI CES } & \\
5000 & Salaries & $\$ 105,910.00$ \\
5010 & Fringe Benefits & $\$ 35,064.00$ \\
& TRAVEL & \\
5101 & Per Diem & $\$ 1,250.00$ \\
5103 & Mileage & $\$ 121.00$ \\
5150 & Training & $\$ 830.00$ \\
5160 & Vehicle Insurance & $\$ 1,170.00$ \\
5190 & Vehicle Expense & $\$ 8,089.00$ \\
& MATERI ALS/ SUPPLI ES \& SERVI CES & \\
5210 & Supplies & $\$ 700.00$ \\
5225 & Materials & $\$ 2,005.00$ \\
5226 & Books/J ournals & $\$ 100.00$ \\
5250 & Non-Capital Equipment & $\$ 650.00$ \\
5400 & Communications & $\$ 1,000.00$ \\
5410 & Postage/Freight & $\$ 150.00$ \\
5436 & Permits/Fees & $\$ 400.00$ \\
5440 & Equipment Rental & $\$ 824.00$ \\
5450 & Printing/Duplication & $\$ 174.00$ \\
5460 & Insurance & $\$ 74.00$ \\
5470 & Repairs/Maintenance & $\$ 758.00$ \\
5770 & Professional Services & $\$ 7,600.00$ \\
6100 & Sub-Contract & $\$ 94,002.00$ \\
& SUB-TOTAL & $\$ 260,871.00$ \\
8500 & I NDI RECT & $\$ 65,129.00$ \\
& SUBTOTAL & $\$ 326,000.00$
\end{tabular}

\section{COST SHARE}

Whole Tree Purchase

$\$ 113,350.00$

Whole Tree Preparation

$\$ 41,650.00$

Entry Right/Tree Harvest

$\$ 2,000.00$

Helicopter Whole Trees

$\$ 116,550.00$

Helicopter Mobilization

$\$ 20,000$

Planting

$\$ 24,000.00$

Fish Passage Barrier Design

$\$ 12,000.00$

Fish Passage Barrier Removal

$\$ 31,000.00$

$\$ 6000.00$

Dam Fishway Design

$\$ 12,000.00$

SUB-TOTAL

GRAND TOTAL

$\$ 378,550.00$

$\$ 704,550.00$ 


\section{LITERATURE CITED}

Alt, D. and D.W. Hyndman 1995. Northwest Exposures: A Geologic Story of the Northwest. Mountain Press Publishing Company, Missoula, MT.

Andrus, C. \& J. Middel 2003. Meacham Creek Watershed Analysis and Action Plan; Final Report. pp. 125, Prepared for the Confederated Tribes of the Umatilla Indian Reservation.

BPA 2008. Bonneville Power Administration, Division of Fish and Wildlife. CTUIR Statement of Work - Umatilla Anadromous Fisheries Habitat Project, as accessed November 19, 2008 on URL:

http://pisces.bpa.gov/release/reports/ReportViewer.aspx?RptName=SOWWorkElements MilestonesPublicVersion\&rs\%3aFormat=PDF\&psReferenceNumber=32047.

Buchanan, D.V. and S.V. Gregory 1997. Development of water temperature standards to protect and restore habitat for bull trout and other cold water species in Oregon. Proceedings of the Friends of the Bull Trout Conference. Calgary, Alberta.

CTUIR 1994. Umatilla Basin Natural Production Monitoring and Evaluation, Annual Progress Report 1992-1993. Prepared by Confederated Tribes of the Umatilla Indian Reservation and submitted to Bonneville Power Administration, Project No. 90-005-01.

CTUIR 1995. Umatilla Basin Natural Production Monitoring and Evaluation, Annual Report, 1993-1994, Prepared by Confederated Tribes of the Umatilla Indian Reservation for U.S. Department of Energy, Bonneville Power Administration, Environment, Fish and Wildlife, Portland, OR, April 1995, Project No. 90-005-01.

CTUIR 2000. Umatilla Basin Natural Production Monitoring and Evaluation Project, Annual Progress Report 1997-1998. Confederated Tribes of the Umatilla Indian Reservation, BPA Project No. 1990-005-01.

CTUIR 2005. Confederated Tribes of the Umatilla Indian Reservation Total Maximum Daily Load For Temperature and Turbidity. Prepared by the Confederated Tribes of the Umatilla Indian Reservation, Department of Natural Resources, Issued by the US Environmental Protection Agency, Region 10, July 2005. Available online at URL: http://yosemite.epa.gov/R10/WATER.NSF/TMDLs/Approved+TMDLs.

CTUIR 2007. Umatilla River Basin Anadromous Fish Habitat Enhancement Project, Document ID P102746, February 1, 2005 - January 31, 2007. Annual Report, Contract Number 00006513, January 2007. Confederated Tribes of the Umatilla Indian Reservation. Submitted to Bonneville Power Administration. Available online as accessed November 19, 2008 at URL:

http://pisces.bpa.gov/release/documents/documentviewer.aspx?doc=P102746.

CTUIR and ODFW 2006. Five-Year Action Plan for the Development and Maintenance of Habitat Improvement Projects in the Umatilla Subbasin: 2006-2010, Prepared 
for/Funded by: U.S. Department of Energy, Bonneville Power Administration, Division of Fish and Wildlife, March 2006.

Hoverson, E. D. 2007. Confederated Tribes of the Umatilla Indian Reservation. Fish Passage Barrier Rectification: Meacham, Camp Creeks, Biological Assessment (U.S. Fish and Wildlife Services), April 10, 2007.

Independent Scientific Group 1996. Return to the River: Restoration of Salmonid fish in the Columbia River Ecosystem, September 1996.

Moore, Kelley M.S., Jones, Kim, K. Dambacher, Jeffrey M. 1993. Methods for stream habitat surveys: Oregon Department of Fish and Wildlife, Aquatic Inventory Project. Corvallis, OR 97730.

Moore, Kelley M.S., Jones, Kim, K. Dambacher, Jeffrey M. 2002. Methods for stream habitat surveys version 12.1: Oregon Department of Fish and Wildlife, Aquatic Inventory Project. Corvallis, OR 97730.

NPPC 1990. Northwest Power Planning Council. Umatilla River Subbasin Salmon and Steelhead Production Plan. Northwest Power Planning Council and the Agencies of the Indian Tribes of the Columbia Basin Fish and Wildlife Authority.

NRC 1996. Upstream. Salmon and society in the Pacific Northwest. National Research Council, Washington D.C.

Rosgen, D.L. (1996) Applied River Morphology. Wildland Hydrology, Pagosa Springs, CO.

Smith, E.P. 2002. BACI Design. pp. 141-148. In: A.H.E.-S.a.W.W. Piegorsc (ed.) Encyclopedia of Environmetrics, John Wiley \& Sons, Ltd, Chichester, 2002.

Taylor, George H. 1993. Normal Annual Precipitation, State of Oregon, Period 1961-1990. Map. Oregon Climate Service, 326 Strand Ag. Hall, Oregon State University, Corvallis, Oregon 97331-2209.

Treaty of 1855. Treaty with the Wallawalla, Cayuse, etc., 1855, June 9, 1855, 12 Stats., 945, Ratified Mar. 8, 1859.

Umatilla/Willow Subbasin Planning Team 2004. Draft Willow/Umatilla Subbasin Plan, Prepared by the Umatilla/Willow Subbasin Planning Team. Prepared for the Northwest Power and Conservation Council, May 28, 2004. Available online from the following URL as accessed November 19, 2008: http://www.nwcouncil.org/fw/subbasinplanning/umatilla/plan/.

Umatilla/Willow Subbasin Planning Team 2005. Final Umatilla Willow Subbasin Plan. Prepared by the Umatilla/Willow Subbasin Planning Team, for the Northwest Power and Conservation Council, May, 2005. 
USFWS (U.S. Fish and Wildlife Service) 2002. Bull Trout Draft Recovery Plan. U. S. Fish and Wildlife Service. Paged by section. Available online from URL: http://ecos.fws.gov/docs/recovery_plans/2002/021129.pdf.

USFWS (U.S. Fish and Wildlife Service) 2005. Final rule: endangered and threatened wildlife and plants; designation of critical habitat for the bull trout. Federal Register 70(185): 56212-56311.

USGS 2008. United States Geological Survey. “Columbia Plateau, Columbia River Basalt”, as accessed November 19, 2008 from URL:

http://vulcan.wr.usgs.gov/Volcanoes/ColumbiaPlateau/description_columbia_plateau.htm $\underline{l}$.

Walker, George W. and Norman S. MacLeod. 1991. Geologic Map of Oregon, U.S. Geological Survey, U.S. Department of the Interior, U.S. Geological Survey Map Distribution, Box 25286, Federal Center, Denver, CO 80225. 